\title{
THE IMPACT OF SYMBIOSIS ON THE HEATING AND COOLING REQUIREMENT OF AN OFFICE BUILDING AND URBAN ROOFTOP GREENHOUSE
}

Andrea Vickers

Bachelor of Science (Architecture), McGill University, 2011

\author{
An MRP \\ presented to Ryerson University \\ in partial fulfillment of the \\ requirements for the degree of \\ Master of Building Science \\ in the Program of \\ Building Science \\ Toronto, Ontario, Canada, 2013 \\ (C)Andrea Vickers 2013
}




\section{Author's Declaration}

I hereby declare that I am the sole author of this MRP. This is a true copy of the MRP, including any required final revisions.

I authorize Ryerson University to lend this MRP to other institutions or individuals for the purpose of scholarly research

I further authorize Ryerson University to reproduce this MRP by photocopying or by other means, in total or in part, at the request of other institutions or individuals for the purpose of scholarly research. I understand that my MRP may be made electronically available to the public. 


\section{Abstract \\ The impact of symbiosis on the heating and cooling requirement of an office building and urban rooftop greenhouse}

Master of Building Science, 2013

\section{Andrea Vickers}

Building Science, Ryerson University

Urban agriculture is an important step towards food security in cities where rooftop space is abundant, and underused. This research addresses the potential impact of adding a rooftop greenhouse to a six storey, detached office building on the total heating and cooling energy consumption of both structures operated year-round, using IES-VE simulation software.

Several variables including the level of insulation between the office building and greenhouse, additional thermal mass, the greenhouse envelope and greenhouse internal loads were tested to observe trends that suggest an impact on the system's conditioning energy due to the presence of the greenhouse.

Overall, it was found to be most likely that the greatest energy savings for an integrated office building and rooftop greenhouse would be achieved with the highest resistance greenhouse envelope possible, which may be limited by the light needs of plants grown in the greenhouse, and incorporation of thermal mass in the greenhouse. 


\section{Acknowledgements}

Dr. Mark Gorgolewski, for involving me in a project on urban agriculture which I am more excited about than ever. Also for encouraging me to pursue energy modelling software, and the insightful thoughts and support along the way.

Dr. Miljana Horvat, my second reader, and all of the professors I have had the privilege of learning from, for providing variously: advice and support, employment, and counselling on the finer points of the science of building.

Tristan Truyens and Dr. Xiangjin Yang, for their troubleshooting support and never-ending advice on all things IES.

Lauren Rathmell of Lufa Farms, for helping me to understand how a commercial rooftop greenhouse works.

Gord Bonisteel of V\&V Agricultural Greenhouses Ltd., for answering all my questions about greenhouse construction, or directing me to those who could.

My friends and classmates at Ryerson University, for a fantastic year.

My family, for their endless love and support. 


\section{Table of Contents}

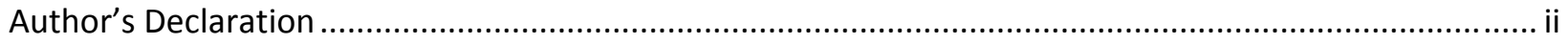

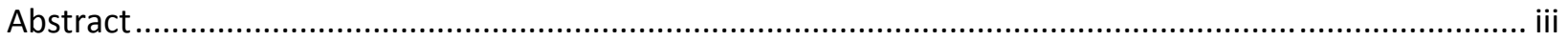

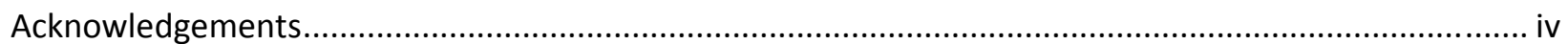

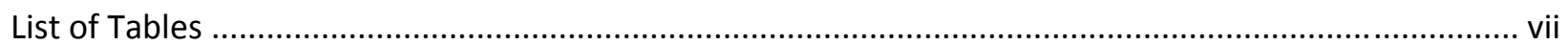

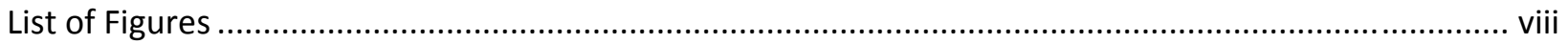

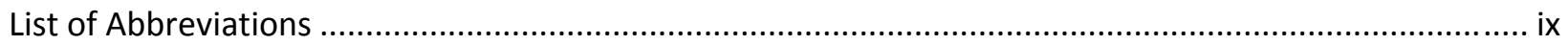

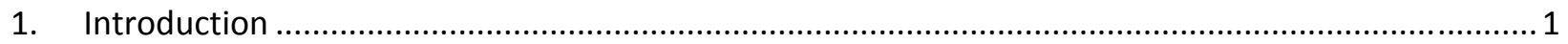

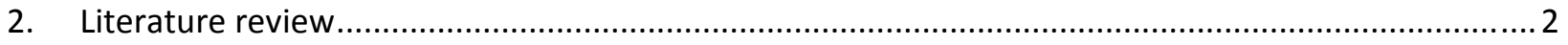

$2.1 \quad$ Opportunity for urban agriculture …................................................................................ 2

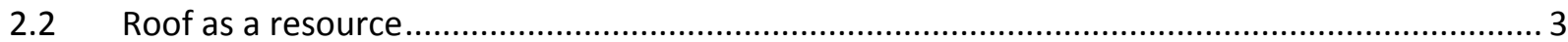

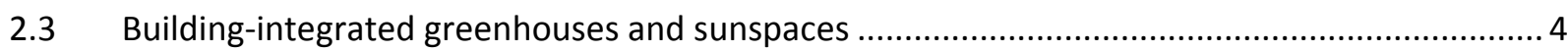

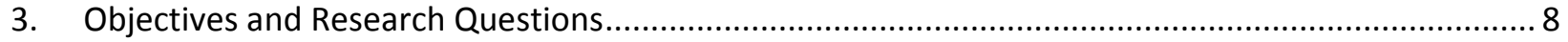

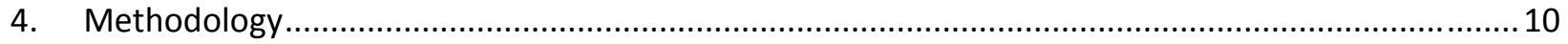

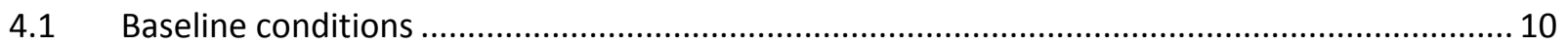

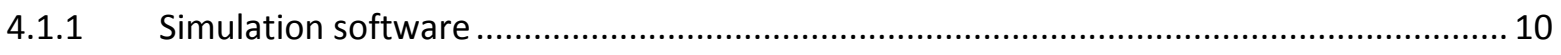

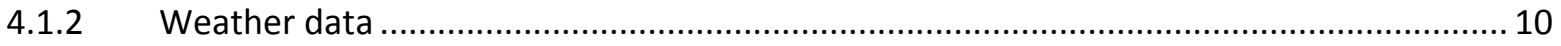

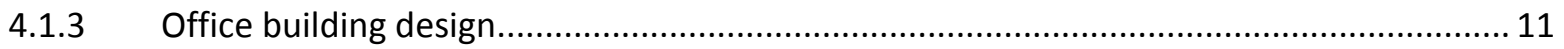

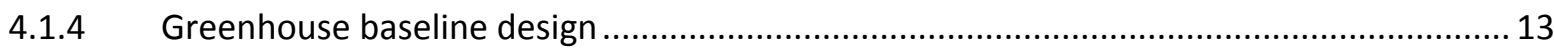

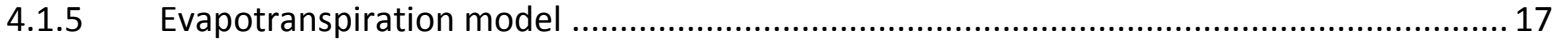

4.1.6 Supplementary lighting model ...................................................................................... 19

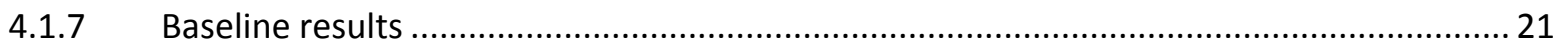

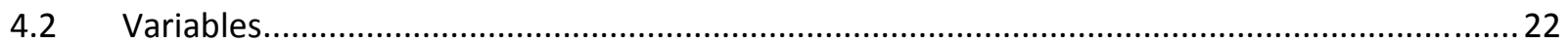

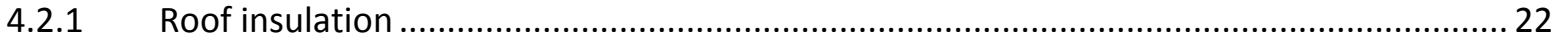

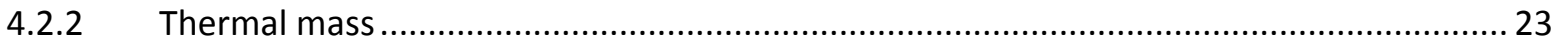

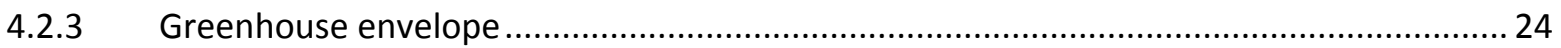

4.2.4 Evapotranspiration and high pressure sodium lights ................................................... 26

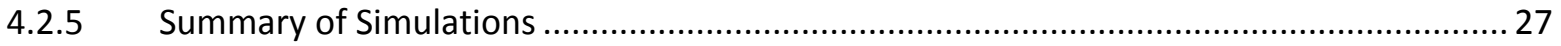

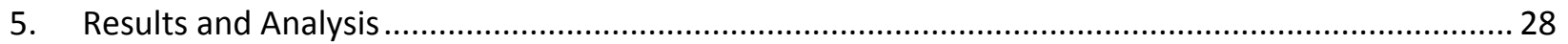

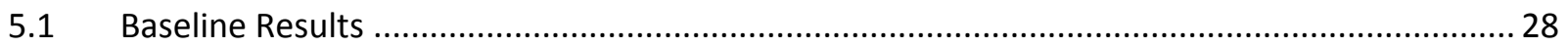

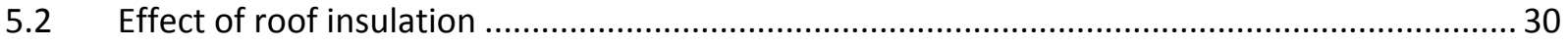

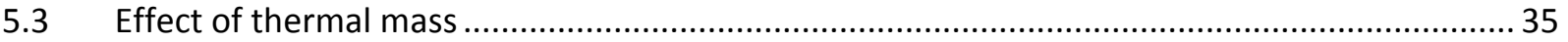




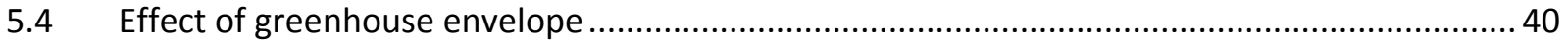

5.6 Effect of evapotranspiration \& high pressure sodium light models ........................................ 46

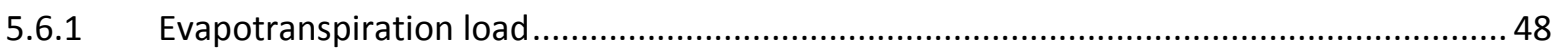

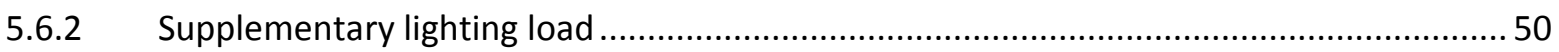

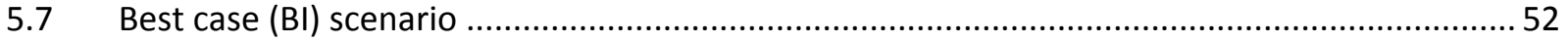

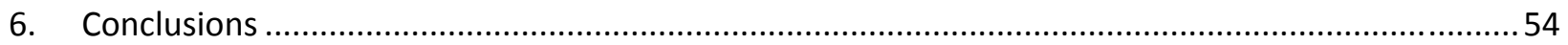

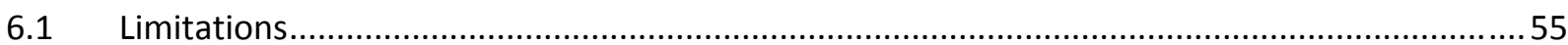

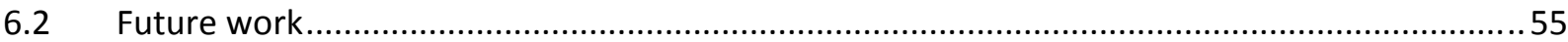

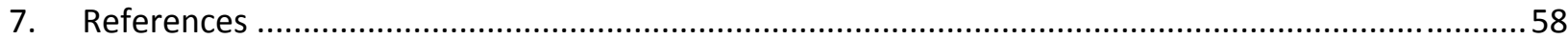

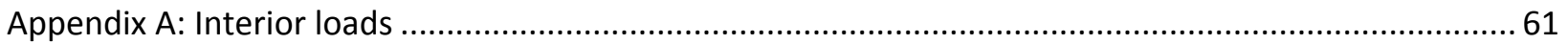




\section{List of Tables}

Table 1: Office building IES-VE simulation model inputs .................................................................... 13

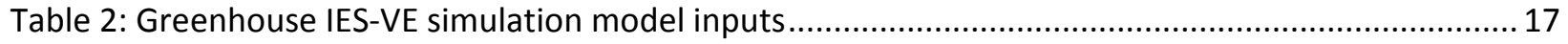

Table 3: Office building roof assembly for standalone and building integrated simulations .................... 22

Table 4: Office building roof assembly with thermal mass in greenhouse for standalone and building

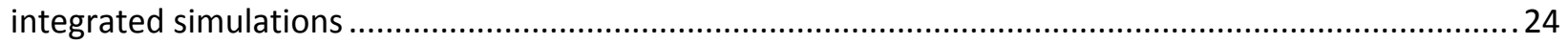

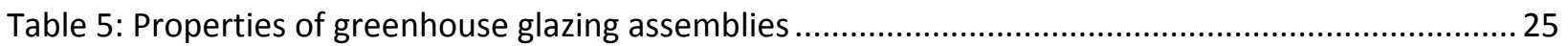

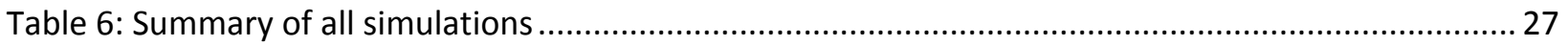

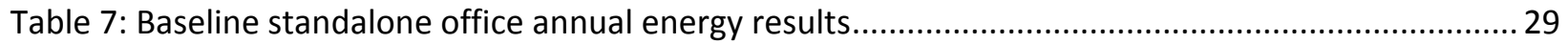

Table 8: Baseline standalone greenhouse annual energy results........................................................ 30

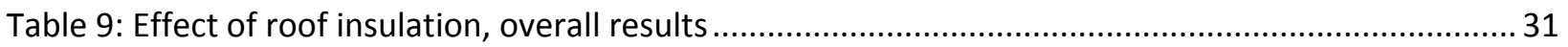

Table 10: Summary of the effect of roof insulation on energy consumption in SA vs. BI ........................34

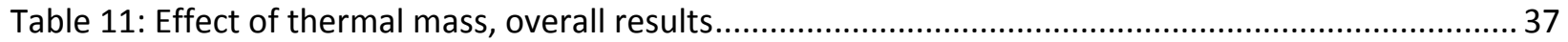

Table 12: Summary of the effect of thermal mass on energy consumption in SA vs. BI...........................39

Table 13: Effect of greenhouse envelope, overall results..................................................................... 42

Table 14: Summary of the effect of greenhouse envelope on energy consumption in SA vs. BI.............. 45

Table 15: Effect of greenhouse interior loading, overall results........................................................... 47

Table 16: Summary of the effect of greenhouse interior loading on energy consumption in SA vs. BI.....52 


\section{List of Figures}

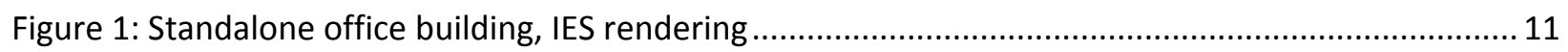

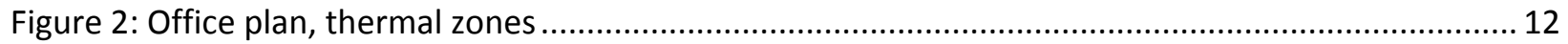

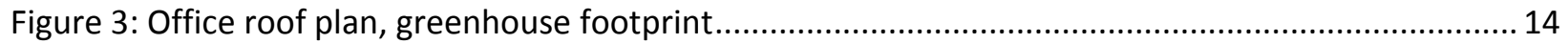

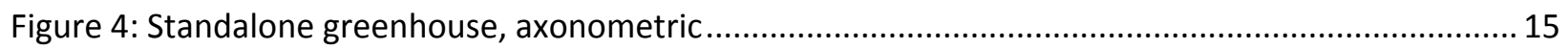

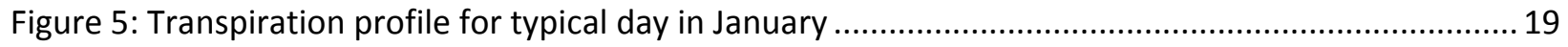

Figure 6: Building-integrated vs. standalone office and greenhouse IES simulation models.................... 21

Figure 7: Office roof plan showing area of changing insulation for standalone and building integrated

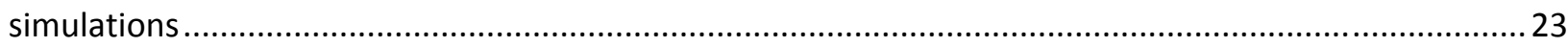

Figure 8: Insulation level scenarios for greenhouse glazing and ET/HPS lights ....................................25

Figure 9: Schematic of temperature readings for calculating heat flux between office and greenhouse 26 Figure 10: Effect of insulation between rooftop greenhouse and office building on the annual heating/cooling energy consumption of the BI system vs. the baseline combined SA ............................3 32

Figure 11: Effect of insulation on the annual heating energy of office vs. rooftop greenhouse in BI system

Figure 12: Annual energy required to heat and cool SA greenhouse with insulation under the slab and

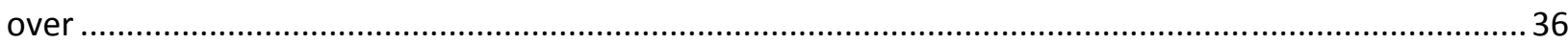

Figure 13: Annual energy required in BI system with no thermal mass/equivalent insulation level, thermal mass in greenhouse, and double thermal mass layer; two insulation levels............................. 38

Figure 14: Comparison of BI systems with thermal mass in the greenhouse vs. the SA baseline...............39

Figure 15: Comparison between baseline roof insulation simulations and thermal mass (inverted assembly) at three levels of insulation

Figure 16: Office heating energy requirement, BI system with no insulation vs. RSI $5.28 \mathrm{~m}^{2} \mathrm{~K} / \mathrm{W}$ in the greenhouse footprint: single glazed, single low-e, double glazed, double low-e in order of increasing RSI value.

Figure 17: Heat flux through RSI $5.48 \mathrm{~m}^{2} \mathrm{~K} / \mathrm{W}$ separation with varying greenhouse envelopes; Jan. 1-10, typ. throughout year.

Figure 18: Annual SA greenhouse heating energy, with and without latent load of ET ........................... 48

Figure 19: SA greenhouse relative humidity, with and without latent load of ET ..................................49

Figure 20: Effect of latent load and HPS lights on greenhouse interior temperature; Feb. 1-10, typ. throughout year. 


\section{List of Abbreviations}

$\begin{array}{ll}\text { AEDG } & \text { Advanced Energy Design Guide } \\ \text { ASHRAE } & \text { American Society of Heating, Refrigerating and Air-conditioning Engineers } \\ \text { BI } & \text { Building Integrated } \\ \text { ET } & \text { Evapotranspiration } \\ \text { EWC } & \text { Electric Water Cooler } \\ \text { HPS } & \text { High Pressure Sodium (lights) } \\ \text { HVAC } & \text { Heating, Ventilation and Air Conditioning } \\ \text { IES-VE } & \text { Integrated Environmental Solutions - Virtual Environment } \\ \text { SA } & \text { Standalone } \\ \text { VAV } & \text { Variable Air Volume }\end{array}$




\section{Introduction}

Urban populations in Canada are consistently on the rise, and as cities expand, agricultural land on the outskirts is displaced (Statistics Canada, 2012). With the loss of agricultural land, there may not always be enough room to produce food for the growing global population. Urban agriculture is, therefore, an important step towards food security in cities. While it may only provide a small portion of the food supply required to support the urban population (MacRae et al., 2010), it is becoming a forum for highlighting responsible agricultural practices, and creates awareness of the food system in urban residents (Lufa Farms, 2013).

A large, and mostly untapped, resource for urban agriculture is the space available on rooftops. Specifically commercial rooftop greenhouses, like Lufa Farms in Montreal and Gotham Greens in New York City, serve to intensify the use of city land and diversify urban employment opportunities. Rooftop greenhouses in the city provide opportunities for food education, and, depending on agricultural intensity, appealing leisure space for users of the host building. Their proximity to consumers also insists on a level of accountability on the part of the growers and delivers unparalleled freshness.

This document presents the results of a research study concerning rooftop greenhouses. The investigation highlights further value in installing a rooftop greenhouse, over a six storey detached office building, by examining the thermal symbiosis of the two structures.

To this point, little research has been conducted on the subject of urban rooftop greenhouses, and no computer simulation models could be found attempting to show thermal symbiosis between the two structures. However, the Seawater greenhouse in London, England has been studied extensively using a calculation method developed in the European Passive Solar Handbook to show that the heating load of the host building is reduced in the winter due to the presence of a rooftop solarium.

A review of academic literature is conducted concerning existing rooftop greenhouses, and other subjects that relate closely to the phenomenon under study including green roofs, double skin facades and attached sunspaces and, more broadly, the opportunity for rooftop urban agriculture in the Toronto context. From this literature review, objectives for the research and four detailed research questions are developed. A detailed methodology is proposed in order to systematically examine a simulated rooftop greenhouse and host office building. Finally, the results of the thermal simulation are outlined, and analyzed in order to draw final conclusions about the research. 


\section{Literature review}

Very little academic literature exists on the synergistic thermal relationship of a rooftop greenhouse with its host building. Research has been done focusing specifically on the direct, intentional transfer of heat, but fewer on the indirect thermal benefits such as those that were investigated in this research (Pervila, Remes, \& Kangasharju, 2012; Scott, 2011). Prominent commercial rooftop greenhouse establishments have only begun operations in the last few years, including Lufa Farms in Montreal and Gotham Greens in New York City (Gotham Greens, 2013; Lufa Farms, 2013) therefore research and publication of initial academic literature may still be forthcoming.

\subsection{Opportunity for urban agriculture}

According to Rodriguez (2009), in a dissertation estimating the productive potential of London, England's rooftops, a "very conservative" yield estimate for greenhouse hydroponic production is 300 tons/ha/yr, meaning that the greenhouse modelled herein $\left(986 \mathrm{~m}^{2}\right)$ could theoretically yield 29 tons of produce annually. As another example, Lufa Farms is a $2880 \mathrm{~m}^{2}\left(31000 \mathrm{ft}^{2}\right)$ commercial production operation, and produces up to 100 tons of produce annually, feeding 2500 people in Montreal (L. Rathmell, personal communication, July 22, 2013). This lends further credibility to the number postulated by Rodriguez, and suggests that the greenhouse under study could provide hydroponic vegetables to more than 800 people at peak production.

Research on urban agriculture in Singapore finds that 35.5\% of the country's fresh vegetable requirement could be provided with building integrated gardens on public housing apartments - as compared to just $5 \%$ production within the borders of the country at present (Astee \& Kishnani, 2010). This would reduce the country's food related carbon footprint enormously, and provide opportunities for both landscape design and community involvement in food production. The study stresses the importance of food security, as the global urban population grows and modern farming practices cause damage to what land is left for food production.

More locally, a study done at York University examined the feasibility of providing $10 \%$ of Toronto's fresh vegetable requirement by aggregating the resources of existing city census farms, empty city plots, and rooftop spaces (MacRae et al., 2010). In total, the city would require 2317 hectares to meet $10 \%$ of Toronto's fresh vegetable needs, although researchers foresee difficulty producing some specific crops in the quantity required to meet current demand. In total, $25 \%$ of the rooftop area identified in a previous study of potential green roof spaces was allocated for food production, totaling approximately $10 \%$ of the city's rooftop area. 
Additionally, incorporating food production into a city on rooftops also saves the energy of long distance transportation, or 'food miles', which are estimated at $4500 \mathrm{~km}$ in the Toronto area for average, imported food (MacRae et al., 2010).

\subsection{Roof as a resource}

A similar area of research involves the building energy reduction potential of green roofs. Niachou et al. (2001) show that a building with a green roof (regardless of the level of roof insulation) benefits from smaller variation in interior temperature due to heat flux through the roof, thereby smoothing over cooling peaks in the summer. In buildings with low levels of insulation, green roofs were estimated to provide an energy savings of $37 \%$, while buildings with moderate to high levels of insulation benefited less ( $4 \%$, and less than $2 \%$, respectively), because of the already reduced heat loss through the envelope. The major benefit of a green roof to the building is therefore the reduced peak heating and cooling loads; the heat load reduction potential has to do with the insulation capacity of the components of the green roof, while the reduction of cooling load is attributed to foliage shading, as well as evapotranspiration by the plants, which provides the roof with an evaporative cooling effect (Jaffal, Ouldboukhitine, \& Belarbi, 2012). As compared with a green roof, the system proposed for this research with a rooftop greenhouse does not benefit directly from a layer of extra insulation, but could benefit from latent heat dissipation - through the latent load of plants to ventilation - reducing the cooling load.

The greenhouse is also comparable to a reflective or 'cool' roof, as the predominant roof material exposed to solar radiation is glass. The heat gain through a traditional dark roof necessitates additional cooling load, while a study by Jo et al. (2010) shows that a reduction by approximately $1.5 \%$ and $3 \%$ of the building's total monthly electricity consumption is achievable in a building with $50 \%$ and $100 \%$ cool roof coverage, respectively.

Parallels with the proposed research are also drawn to literature concerning the energy performance of buildings incorporating double-skin facades, which can be compared with the greenhouse on the roof. In their study of double skin facades, Zhou \& Chen (2010) identify the technology as being an effective collector of solar radiation to reduce the heating and cooling energy required by the building. Especially pertinent is a study conducted on double skin facades using plants as the shading device. Stec et al. (2005) found that the temperature of all layers of the double facade, including the internal wall, was reduced when plants were used as the shading device as compared with blinds ( $20 \%$ reduction) or no shading. Plants not only block solar radiation from reaching the interior surface through shading, but 
convert solar energy to both latent and sensible forms to dissipate the heat, as the plants in the greenhouse will do.

\subsection{Building-integrated greenhouses and sunspaces}

Anecdotally, Lufa Farms' rooftop greenhouse in Montreal was shown to use only $60-70 \%$ of the energy of a traditional rural detached ground level greenhouse (L. Rathmell, personal communication, May 6, 2013). This provides a good indication that there is an energy benefit to an urban rooftop greenhouse, although it does not clarify the mechanism that causes the greenhouse to perform so much better.

Research similar to the current investigation has been conducted at the University of Sheffield, specifically with respect to a rooftop greenhouse in Hackney, London called the Seawater Greenhouse, retrofitted onto a two storey office/workshop. The greenhouse is not fully glazed and therefore more akin to a solarium. Scott (2011) investigated the rooftop greenhouse/solarium space using a manual calculation method called New Method 5000, outlined in the European Passive Solar Handbook (Goulding, Owen, \& Steemers, 1992). Alongside a well insulated office building, using preheated ventilation air from the greenhouse, the heating requirement was reduced by almost $50 \%$. As a result, the office building is only heated in December and January to maintain occupant thermal comfort (assuming an office setpoint temperature of $21^{\circ} \mathrm{C}$ ). It is not discussed what temperature is able to be maintained in the greenhouse at night, as it focuses mainly on the level of savings possible in the office. A brief study of greenhouse envelope materials showed double polycarbonate glazing reduced the heating requirement of the building most significantly. It had about the same effect as a steel frame, timber stud (non-glazed) storey, and performed better than either single glazing or polythene. The study was done with limited observational data from the heating season only, and does not investigate the effect of plants in the greenhouse. Also, the heat is actively vented from the greenhouse to the rest of the building instead of the exclusively indirect transfer investigated herein.

In a Mediterranean climate, the evaporative pad cooling system of a computer simulated rooftop greenhouse was able to entirely replace the HVAC system of its cooling-dominated host office building, in addition to taking care of the needs of the greenhouse (Caplow \& Nelkin, 2007). It was found that the greenhouse is able to replace the office HVAC system by ventilating air from the greenhouse into the office building for low-grade cooling. This use of the rooftop space for a greenhouse not only adds productive capacity to the building overall, but eliminates the need for a fossil fuel or electric powered cooling system in the office building, replaced instead by the evaporative cooling system involving only a 
small energy for fans. This system is contingent on a sustainable supply of water (rainwater or reverse osmosis of ocean water is suggested).

Using the same system (greenhouse + two storey building) from the research by Caplow \& Nelkin (2007) except in the London climate, Delor (2011) also investigated controlled environment building integrated agriculture, focusing specifically on hydroponic rooftop greenhouses. Delor also used the New Method 5000 (from the European Passive Solar Handbook) and found that a well insulated office building, with the addition of a well insulated rooftop greenhouse, could benefit from a $13 \%$ decrease in annual heating energy as compared with the identical separated building and greenhouse. In a poorly insulated building, the addition of a rooftop greenhouse saved $41 \%$ energy annually. This assumes an active transfer of waste heat from the greenhouse to the office building, and vice versa. Delor also indicates that while green roofs perform better than rooftop greenhouses to prevent heat loss, rooftop greenhouses can be used for both solar heat gains and evaporative cooling.

Attached sunspaces are closely related to rooftop greenhouses, and were investigated to ascertain whether their trends correspond with the current research. One such investigation considered an attached sunspace on a small, single-zone structure using TRNSYS modelling software, in 4 climates in Europe (Milan, Dublin, Athens and Florence) and on two representative days of the year, January 12 and July 4 (Mihalakakou \& Ferrante, 2000). The structures with an attached sunspace were shown to have higher temperatures than those without by up to $5^{\circ} \mathrm{C}$ in the coolest climate (Dublin), which is beneficial in January, but causes overheating problems in July. Further tests conducted on the same space in the Milan climate only, showed that maximum air temperatures in the sunspace were approximately $1^{\circ} \mathrm{C}$ and $5^{\circ} \mathrm{C}$ lower in January and July respectively when the concrete floor was exchanged for a planted grass floor. This amounts to a reduction in the effectiveness of heat supply in the winter, but a cooling effect of up to $6^{\circ} \mathrm{C}$ for the attached structure in the summer. Lastly, a double glazed sunspace demonstrated higher temperatures in the winter and lower temperatures in the summer; this second result does not seem to align with the results of other studies consulted below.

Swann (1996) also investigated adding a glazed space to a simulated residential house in London, connected with a glazed wall. In the winter, heat loss through the glazed space demanded increased energy for space heating, which was counteracted only by increasing the resistance of the glazing. However, in the summer the unventilated glazed space increased the hours of overheating in the adjacent rooms, and this period of overheating increased with higher insulation values of the glass. Adding thermal mass to the floor of the glazed space, in replacement of a carpet floor, was not found to 
reduce peak temperatures or improve the number of comfortable hours. Through various different configurations of the glazed space's construction, envelope and orientation, little energy saving was found with a glazed space simply in "buffer mode", that is, with no active transfer of heat to or from the residential space. The buffer effect, as described by Swann, derives from the fact that the glazed space is always a few degrees above ambient temperature even under overcast skies, thereby providing a buffer to the residential space against heat loss. This effect becomes more prominent when the residential space is less well insulated, suggesting another avenue for investigation beyond the research study following, perhaps indicating the type of building most suited for a retrofit involving an attached glazed space.

Finally, another study investigated a glazed space integrated into a computer simulated end unit row house of typical construction, in the climate of Zurich, Switzerland (Hastings, 1981). The scenario run with a double glazed envelope on the sunspace yielded the highest temperatures in the sunspace, agreeing with the result found by Swann (1996), but contrary to the results of Mihalakakou \& Ferrante (2000). Overall, the house with an attached sunspace required more heat in the coldest part of winter than a house without a sunspace, but the difference was recovered in the shoulder seasons (fall/spring). It was also shown that a house with a well insulated wall in the area common to the house and sunspace had a smaller annual heating load than with an uninsulated dividing wall. Each of these variables was investigated with the rooftop greenhouse herein, the expectation being that many of the same trends would be observed.

Therefore, most importantly:

- Latent heat dissipation by green roof plants and reflection by high albedo surfaces are shown to lessen the cooling load of attached spaces (Jaffal et al., 2012; Jo et al., 2010).

- The use of greenhouse envelopes with high resistance can help to reduce overall energy consumption (Scott, 2011).

- A well insulated rooftop greenhouse and office envelope result in a smaller reduction of energy consumption than poorly insulated envelopes (though with active venting, the greenhouse is found to reduce energy consumption) (Delor, 2011).

- An attached sunspace causes the host structure to be warmer year round, though may cause overheating in the summer; a planted area in the sunspace can lead to a cooling effect reducing instances of overheating (Mihalakakou \& Ferrante, 2000). 
- The "buffer effect" is found to provide little overall energy savings to the attached structure when there is no active transfer of heat from the sunspace (Swann, 1996); however active venting of heat from greenhouse could significantly reduce energy consumption (Delor, 2011; Scott, 2011).

- Structures with an attached sunspace need more heating in winter, but make up for the difference (i.e. requires less heating when sunspace is present) in the shoulder seasons (Hastings, 1981). 


\section{Objectives and Research Questions}

This research explores the impact of an urban rooftop greenhouse on the annual heating and cooling energy requirement of the greenhouse and the host office building below. The broader purpose of the research is to establish whether there is value, beyond local produce, in providing urban agriculture on a rooftop.

This concept follows from previous research examining the impact of attached sunspaces on their host building, as well as other rooftop greenhouses connected to structures of various occupancy. Findings suggest that the parameters of the glazed space can be modified to decrease heating and/or cooling requirements in the host building although some studies suggest that without active heat transfer (by a ventilation system, or otherwise) this effect is not large (Hastings, 1981; Swann, 1996). The research is also informed by studies of the effect of green roofs on the energy performance of buildings. Research has found that green roofs provide reductions in the heating and cooling load of buildings through evapotranspiration of plants, and shading from foliage (Jaffal et al., 2012; Niachou et al., 2001). This research will examine the impact of these parameters as they apply to integrated rooftop greenhouses.

Specifically, several factors were tested using IES-VE energy simulation software to determine their level of impact on a simulated greenhouse, and mid-rise office building. The four major questions addressed in this research are outlined below.

i. How does the level of insulation in the area of roof common to both structures impact the total heating and cooling requirement of the greenhouse, and the office building below?

ii. How does the addition of thermal mass in the greenhouse affect the total heating and cooling requirement?

iii. What effect do the properties of the greenhouse envelope have on the heating and cooling requirement?

iv. What effect do evapotranspiration and supplementary greenhouse lighting have on the heating and cooling requirement?

The research sought specifically to determine whether there is an impact on the energy required for heating and cooling in both structures due to crops and supplementary lighting, insulation in the area of roof common to both structures, a changing greenhouse envelope and thermal mass in the greenhouse. By changing these variables in a simulation model, trends were shown indicating whether interconnectedness of the pair benefits the total heating/cooling load of the systems combined, or not. 
The ultimate goal is a reduction in the total energy necessary for heating and cooling to maintain occupant thermal comfort in the office building, and appropriate growing conditions year round in the greenhouse.

The study herein used for analysis a simulated hydroponic agricultural greenhouse, operated year round on the rooftop of a simulated mid-rise detached office building. The heating, ventilation and air conditioning (HVAC) systems were separate for each structure to allow for independent simulation of the greenhouse and the office building, and to distinguish to what extent each structure is impacted by their connection. 


\section{Methodology}

\subsection{Baseline conditions}

The office building was designed to represent a typical six-storey, steel frame building located in Toronto. The baseline office building remained the same through all iterations, except for the level of roof insulation which was modified to collect data for the first and second research questions. The greenhouse was designed based on the office building roof conditions and geometry, and information from the Lufa Farms greenhouse; simplified as required. Full specifications are included below.

\subsubsection{Simulation software}

Initially, the host office building and greenhouse were designed and modelled in IES Virtual Environment (IES-VE 6.4.0.12). For this research, the energy modelling software was used evaluate trends in the energy required annually for heating and cooling in a greenhouse and office building with changing variables and configurations, for a total of 75 simulations. The software was also used to gather data on parameters associated with each simulation such as indoor environment and heat flux through assemblies.

Research has been done previously on a rooftop greenhouse, the Seawater greenhouse in London, with a method of calculation developed in the European Passive Solar Handbook (Goulding et al., 1992). Unlike research done using hand calculations, IES-VE simulation software was chosen to avoid many of the simplifying hypotheses innate in hand calculations and offer the highest level of precision available. IES-VE was also chosen for the industry professionals readily available to verify the accuracy of model inputs (Tristan Truyens - DIALOG, Xiangjin Yang - MCW Consultants Ltd.). The ApacheHVAC module in IES offered maximum controllability of the HVAC system, and allowed manipulation and monitoring of individual HVAC components which would not have been possible with a more simplified software interface such as that of eQUEST. The MacroFlo module controls natural ventilation, which was customized to reflect natural ventilation in a greenhouse.

\subsubsection{Weather data}

In examining weather data, the hope was to find that a downtown urban weather file would exhibit diurnal variations in the dry-bulb temperature consistent with an urban heat island effect. This could represent a major factor in the reduction of energy of urban rooftop greenhouses, i.e. Lufa Farms in Montreal, which uses much less energy to operate than an exposed, rural greenhouse. However, IES software has limited weather data built-in, therefore the Toronto weather file used could not easily be compared with a rural file to learn whether the expected differences exist. Future research should 
ensure the Toronto urban weather file demonstrates the effect of the city's thermal mass, or else use a different file with weather data taken from downtown. Alternatively, a study may be done adding adjacent buildings directly to the energy model as a form of thermal mass to observe their effect on the greenhouse, or even simply changing the level of thermal mass present in the construction of the host building.

\subsubsection{Office building design}

The office building (Figure 1) is assumed to have sufficient structural capacity to support a rooftop greenhouse, and is located in an area with access to unobstructed sunlight, which is not likely to change (i.e. reasonable height zoning limitations exist in the area). The existing roof, without a greenhouse, is dark coloured, and non-reflective. The addition of a rooftop greenhouse is assumed to comply with zoning limitations. Finally, the office building is located in an area with a sufficient residential population as might benefit from local agriculture.

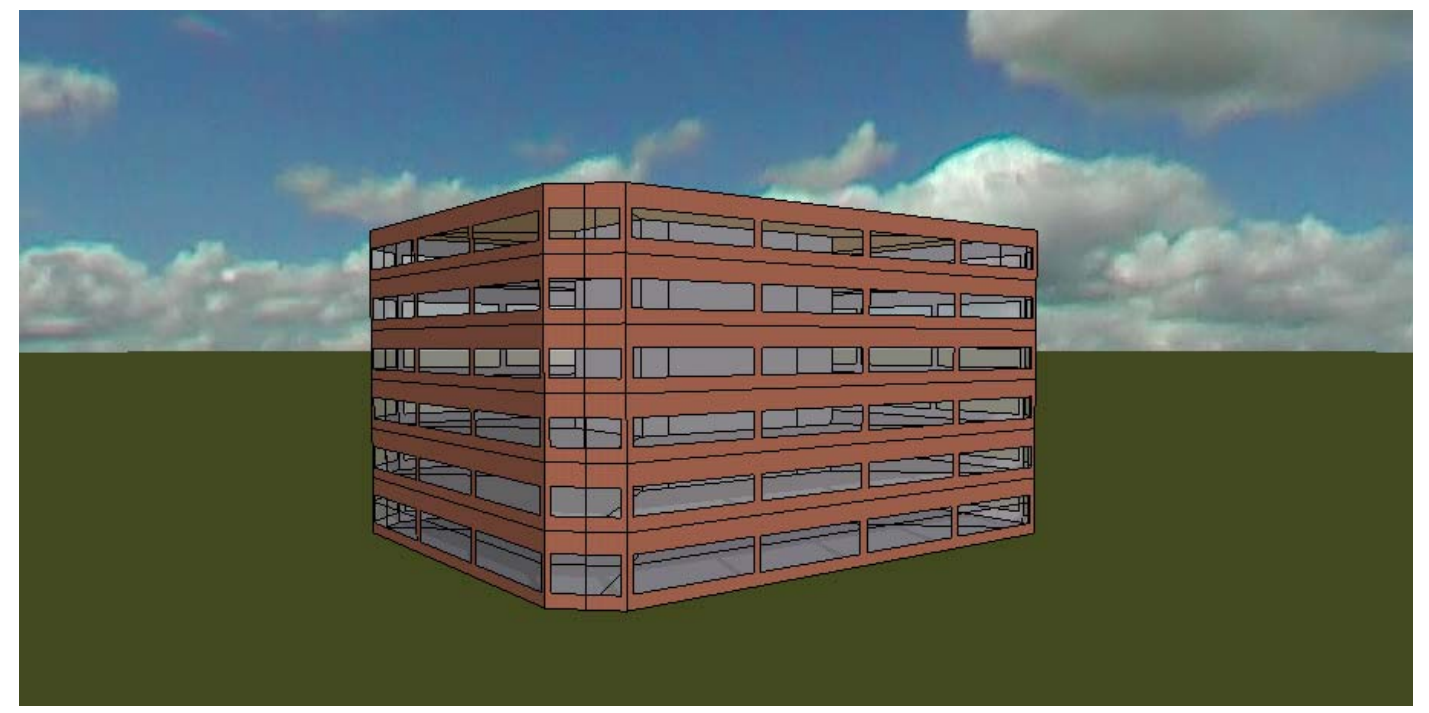

Figure 1: Standalone office building, IES rendering

The baseline building is built to the standards set out in ASHRAE's Advanced Energy Design Guide (AEDG) for Small to Medium Office Buildings where applicable, as the designed office building matches the scope of the guide in floor area, and occupancy (American Society of Heating, Refrigerating and AirConditioning Engineers, 2011).

The office building was divided into 7 thermal zones per floor (Figure 2), according to the recommendations for zoning set out in the EE4 Modelling Guide (Natural Resources Canada, 2008). Each zone was given internal loads corresponding to their use as laid out in the ASHRAE 90.1 standard, for 
equipment, lighting, and occupancy. The ASHRAE 90.1-2007 specified loads are built into IES software (magnitude, and daily profiles including weekdays, weekends and holidays) and were therefore adopted automatically, though the standard may also be consulted (American Society of Heating, Refrigerating and Air-Conditioning Engineers, 2010).

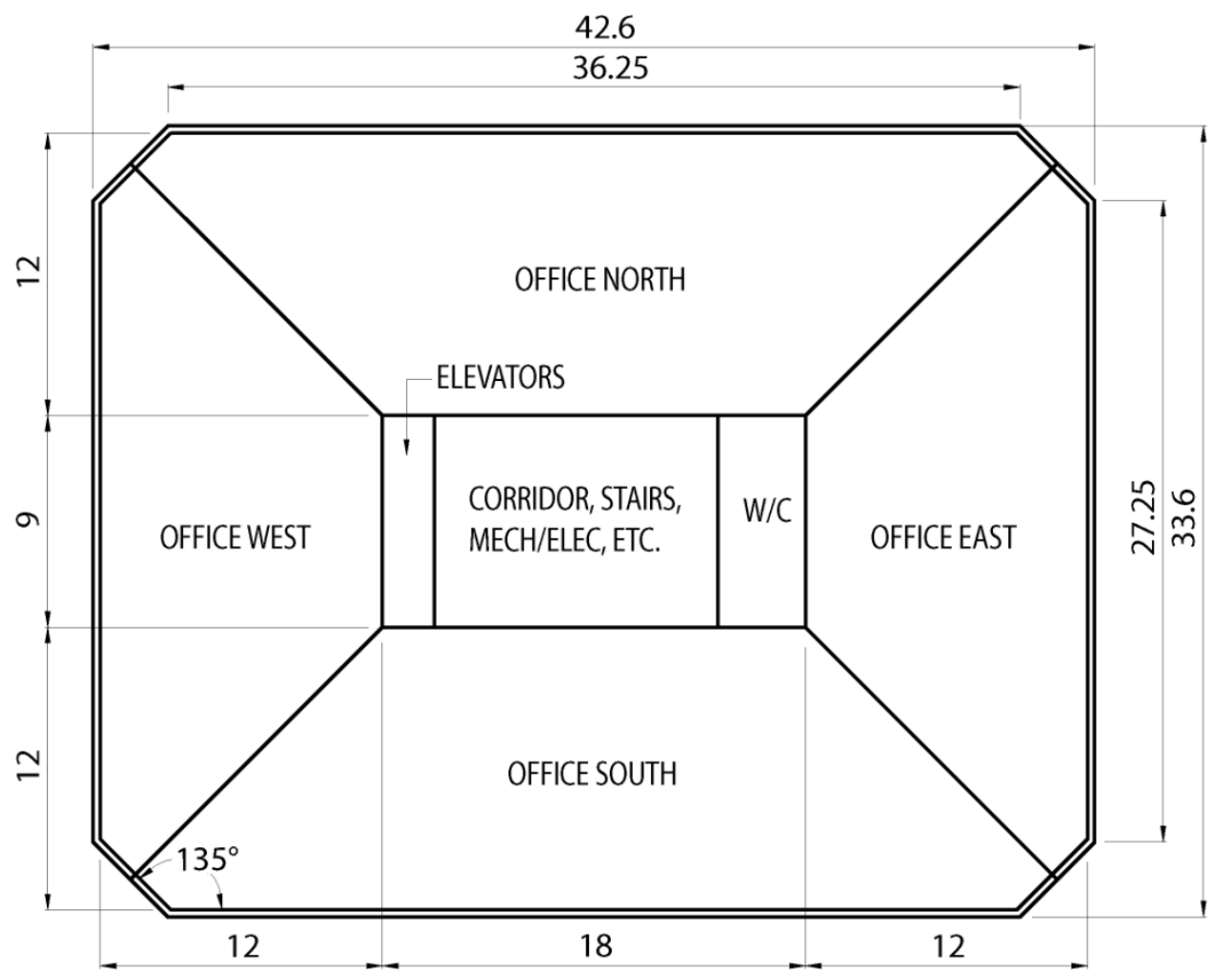

Figure 2: Office plan, thermal zones

The office building parameters for entry into the model are summarized in Table 1. 
Table 1: Office building IES-VE simulation model inputs

\begin{tabular}{|l|l|}
\hline Office building model inputs & Steel-frame \\
\hline Structure & $8467 \mathrm{~m}^{2}\left(91138 \mathrm{ft}^{2}\right)$ \\
\hline Floor Area & $1411 \mathrm{~m}^{2}$ \\
\hline Footprint & Toronto, ON, Canada - Toronto Island Airport \\
\hline Climate data & RSI $2.29+\mathrm{RSI} 2.75$ continuous insulation \\
\hline ASHRAE AEDG base values & $\begin{array}{l}\text { RSI } 5.28 \text { c.i., insulation entirely above deck (100mm concrete pad, } \\
\text { thermal mass) }\end{array}$ \\
\hline Wall insulation & RSI 3.0 \\
\hline Roof insulation & Non-metal frame, U-0.35, SHGC 0.26 \\
\hline Ground contact insulation & $20-40 \%$ (40\% glazed area chosen) \\
\hline Vertical fenestration & $\begin{array}{l}\text { VAV-reheat; hot water boiler (condensing boiler - 90\% rated } \\
\text { efficiency); EWC chiller (IES system 07a) }\end{array}$ \\
\hline Window-to-wall ratio & max. 1.5 L/s per person, $90 \%$ condensing boiler efficiency \\
\hline Systems & $0.8 W / \mathrm{m}^{2}$ \\
\hline HVAC & $21 / 17$ \\
\hline Service hot water & $24 / 26 *$ daytime temperatures comply with ASHRAE 55 \\
\hline Lighting power density & \\
\hline Temperature setpoints & $\begin{array}{l}\text { Heating season } \\
\text { occupied/unoccupied }\left({ }^{\circ} \mathrm{C}\right)\end{array}$ \\
\hline $\begin{array}{l}\text { Cooling season } \\
\text { occupied/unoccupied }\left({ }^{\circ} \mathrm{C}\right)\end{array}$ &
\end{tabular}

\subsubsection{Greenhouse baseline design}

The greenhouse is designed to cover the largest area of the roof possible, approximately $70 \%$ of the office building roof, to deliver the maximum floor-to-wall-area ratio, in an east-west orientation for maximum solar radiation capture. It is set back from the edge of the roof to allow for maintenance, some HVAC exits where necessary, and for compliance with fire code (i.e. glazing, in an urban fabric, requires a minimum separation from adjacent buildings). The setback is a minimum of $2.3 \mathrm{~m}$ diagonally at the corners, as compared with $2 \mathrm{~m}$ on all sides at Lufa Farms (Figure 3). 


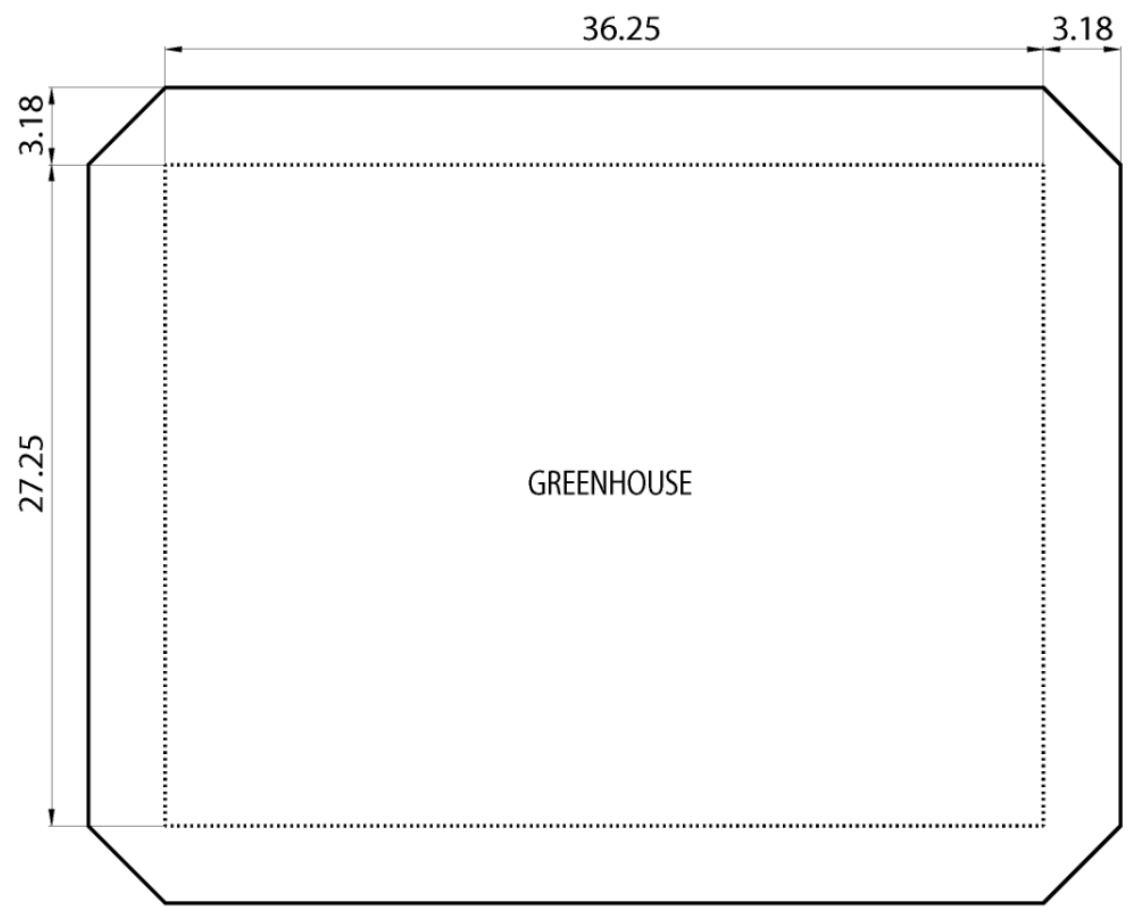

Figure 3: Office roof plan, greenhouse footprint

The greenhouse is a typical Venlo design - multi-span construction with gable roofs - based on the operating rooftop greenhouse of Lufa Farms in Montreal; $4.2 \mathrm{~m}$ to the gutter, and an additional $1.5 \mathrm{~m}$ to the gable (Figure 4). The greenhouse used by Lufa Farms in Montreal was manufactured by Westbrook Greenhouse Systems Ltd., and is the 'Solar' greenhouse model: a multi-span, curved glass greenhouse. The geometry was simplified in order to input the design into IES-VE simulation software; a pointed gable roof instead of curved vaults. Curved glass is, however, ideal in practice because it allows for maximum light transmission to the plants, optimizing their growth (Hadley, 2011). 


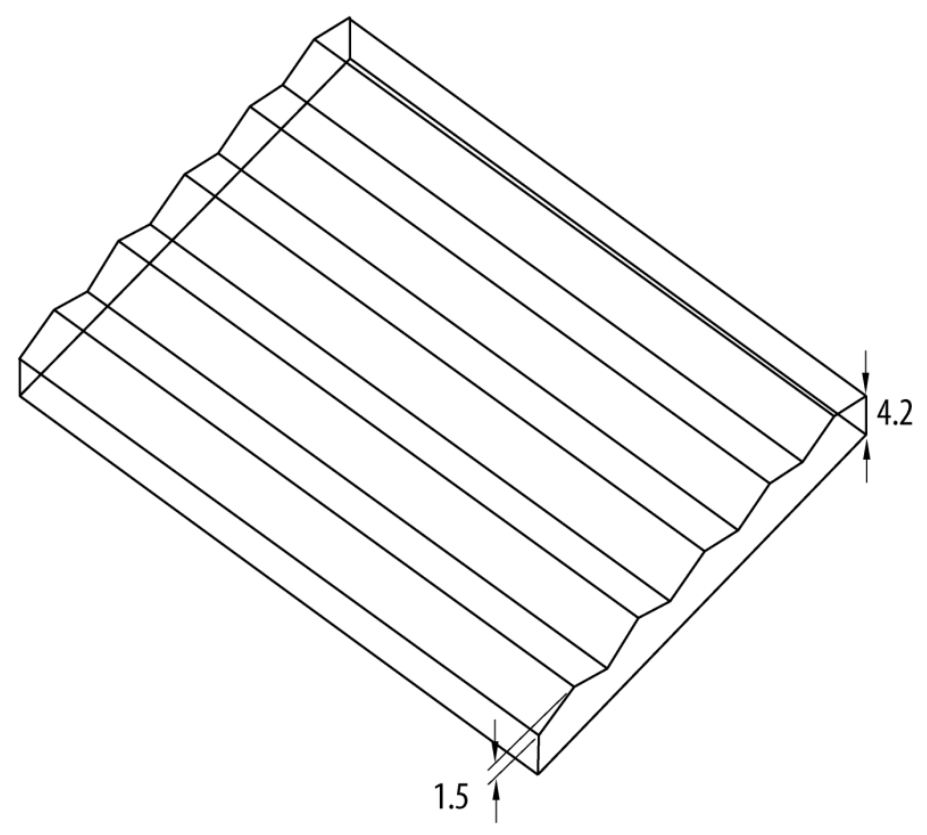

Figure 4: Standalone greenhouse, axonometric

The greenhouse envelope options were developed in consultation with Gord Bonisteel, owner and operator of V\&V Agricultural Greenhouses in Kingsville, Ontario, and Guardian Glass, a glass manufacturer that supplies glass for greenhouses, among other applications. Shading in a greenhouse by the roof structure is typically between 5-6\%, while the structure of the greenhouse accounts for an additional 3\% shading (G. Bonisteel, personal communication, May 30, 2013); therefore the overall vision area of the glass is $91 \%$. The recommended glazing for a greenhouse is $4 \mathrm{~mm}$ tempered single pane glass, which has both high visible transmittance for good crop growth and high impact resistance for durability (Guardian Glass, personal communication, May 30, 2013).

The properties of the single glazed glass were obtained directly from Guardian Glass. The centre-of-glass U-value was input into IES software which automatically calculated the total U-value arising from the window construction based on the window to frame area, with aluminum mullions. The other greenhouse envelope assemblies are described in detail, including this baseline, in the section Effect of thermal mass (page 35).

When the greenhouse is simulated as a standalone structure, the underslab insulation is at a baseline of RSI $2.64 \mathrm{~m}^{2} \mathrm{~K} / \mathrm{W}$ which corresponds with the $\mathrm{CMHC}$ recommendation for insulated slab on grade foundations, i.e. $50 \mathrm{~mm}$ (2") of Type II, III, IV rigid foam (Canadian Mortgage and Housing Corporation, 2000). 
The greenhouse is heated using the equivalent of radiators run by a high efficiency condensing boiler, though in the software the energy is drawn by direct acting electric heaters with a $90 \%$ efficiency (representing the efficiency of the condensing boiler). The energy reported should be the same over an annual period, as auxiliary HVAC equipment (associated pumps and fans) is not being considered. Any differences may result from the lack of a performance curve with direct acting electric heaters, which would be associated with a boiler. Additionally, there may be small difference in diurnal temperature fluctuations between a gas radiator system and electric heaters because of how they are controlled; this will be kept in mind when evaluating daily results. There is no dedicated cooling system in the greenhouse, only mechanical and natural ventilation. The cooling energy is considered to be the energy of the ventilation fans.

The greenhouse setpoint temperatures are based on those at the Lufa Farms rooftop greenhouse, which are $22^{\circ} \mathrm{C}$ during the day in the heating season, $18^{\circ} \mathrm{C}$ at night, and $26^{\circ} \mathrm{C}$ in the cooling season, though outdoor temperatures are maintained when appropriate with ventilation. In the Lufa Farms greenhouse, cooling season temperatures are achieved with an evaporative pad cooling system in addition to ventilation, while in this model a simplified ventilation-only system was used. Additionally in future work, the greenhouse cooling system should maintain the relative humidity at $60-80 \%$ for crop growth, to maintain hydration and prevent mould growth (L. Rathmell, personal communication, May 6, 2013; Agriculture and Agri-Food Canada, 1987). The very minimum recommended temperature in a greenhouse is $10^{\circ} \mathrm{C}$, however lettuce, tomato and cucumber night temperatures should be in the range of $13-18^{\circ} \mathrm{C}\left(55-65^{\circ} \mathrm{F}\right)$ (Aldrich \& Bartok, 1994). Plant development is hinged on the daily average temperature, which is recommended to be around $21^{\circ} \mathrm{C}$. With a setpoint of $22^{\circ} \mathrm{C}$ in the heating season, the average is approximately correct.

The basic internal loading was set based on ASHRAE 90.1 Space-by-space method for 'Active storage', with a moderate equipment and lighting load (American Society of Heating, Refrigerating and AirConditioning Engineers, 2010). This moderate loading was recommended to best represent limited equipment use, and periodic task lighting (separate from supplementary crop lighting) (T. Truyens, personal communication, May 28, 2013).

Various rules of thumb exist to size a mechanical ventilation system, the most common of which recommends that the system be capable of changing the volume of the greenhouse in 2-3 minutes (Agriculture and Agri-Food Canada, 1987). This translates to a capacity of between $27000-40000 \mathrm{~L} / \mathrm{s}$. The greenhouse ventilation fans were auto-sized by IES to $5000 \mathrm{~L} / \mathrm{s}$, as much of the ventilation volume 
required is achieved through natural ventilation. The fan capacity was tested early on at $20000 \mathrm{~L} / \mathrm{s}$ with very little change observed to temperatures in the greenhouse, therefore remained at $5000 \mathrm{~L} / \mathrm{s}$ total for testing.

Because there was no active cooling in the greenhouse, a certain lack of controllability was accepted in the simulations. The ventilation system allowed the greenhouse to maintain temperatures between 21$38^{\circ} \mathrm{C}$ with lows of not less than $10^{\circ} \mathrm{C}$. These maximum and minimum temperatures were tracked for each simulation, and while they are not maintained for long periods of time, they are indicative of the effectiveness of both building integration and the variable under examination. In the summer, temperatures approaching the maximum are reached on almost a daily basis, while the minimum temperatures (when they fall far below the setpoint temperature) are typically only reached a dozen or fewer times in the heating season and seem mostly to indicate that the HVAC system has trouble adjusting quickly to changing internal loads; an improvement that should be explored in future systems.

Additionally, no attempt at humidification was made in the greenhouse, other than the latent load added to represent crop evapotranspiration (see Effect of evapotranspiration \& high pressure sodium light models, page 46), but represents an opportunity for valuable future research on the maintenance of an ideal greenhouse interior climate. This is largely contingent on having a detailed internal loading strategy for greenhouse plants, as they will greatly inform both the relative humidity and temperature.

A summary of the model input parameters for the greenhouse are listed in Table 2.

Table 2: Greenhouse IES-VE simulation model inputs

\begin{tabular}{|l|l|}
\hline Greenhouse model inputs & Steel-frame \\
\hline Structure & $986 \mathrm{~m}^{2}$ \\
\hline Floor Area & Toronto, ON, Canada - Island Airport \\
\hline Climate data & $4 \mathrm{~mm}$ single pane horticultural glass, aluminum mullions \\
\hline Cladding & $\begin{array}{l}\text { Hot water boiler (condensing boiler - } 90 \% \text { rated efficiency); natural } \\
\text { and mechanical ventilation (IES system 09h) }\end{array}$ \\
\hline Systems & \multicolumn{2}{|l|}{ HVAC } & $22 / 18^{\circ} \mathrm{C}, \mathrm{RH} 60-80 \%$ \\
\hline Climate setpoints & $26^{\circ} \mathrm{C}, \mathrm{RH} 60-80 \%$ \\
\hline Heating season &
\end{tabular}

\subsubsection{Evapotranspiration model}

An important consideration in this study is the inability of IES-VE software to model crops directly, although evapotranspiration may have a large impact on thermal relationships. In place of plants, an interior latent load was incorporated to mimic the presence of plants ( $T$. Truyens, personal 
communication, April 25, 2013). This substitution does not fully represent the dynamic benefit of the presence of plants, and suggests an opportunity for further research using more advanced energy modelling software with this capability.

In their investigation of the effects of exterior climactic conditions on greenhouse crop transpiration, Boulard \& Wang (2000) indicate that in closed greenhouses (i.e. much of the growing season in Toronto, due to the cold), heat and water vapour released from crops will accumulate in the greenhouse because of the boundary between interior and exterior; at equilibrium, the crops' transpiration rate will respond closely to external factors, specifically net radiation received. The dissertation by Stanghellini (1987) concerning the effect of microclimate on crop transpiration in the Dutch climate was one of the original models developed to predict transpiration levels in a greenhouse, and indicated that in a moderate climate (specifically that of the Netherlands), net radiation could be used to determine levels of transpiration of a tomato crop in a greenhouse, based on constant interior temperature and humidity.

The final model was developed by taking an average of the daily maximum global radiance values for each month from the IES Toronto weather file, to establish a peak value for conversion to a transpiration level using charts developed by Stanghellini (1987). Two transpiration levels were calculated from the charts as a function of the average monthly temperature and humidity (also calculated based on information in the Toronto weather file), first during the day, then at night. The transpiration latent load was kept constant during the night since the level of radiance does not change (no sun, no radiance). The load was assumed to peak at midday (noon), at the transpiration level determined with Stanghellini's charts. From sunrise to midday, the level would increase from night time levels to the peak, and from midday to sunset, the level dropped back to the night time level. An example of a profile is shown in Figure 5, where the $y$-axis demonstrates at what percentage the transpiration level is set, based on a maximum $(100 \%)$ of $205 \mathrm{~W} / \mathrm{m}^{2}$, latent load. 


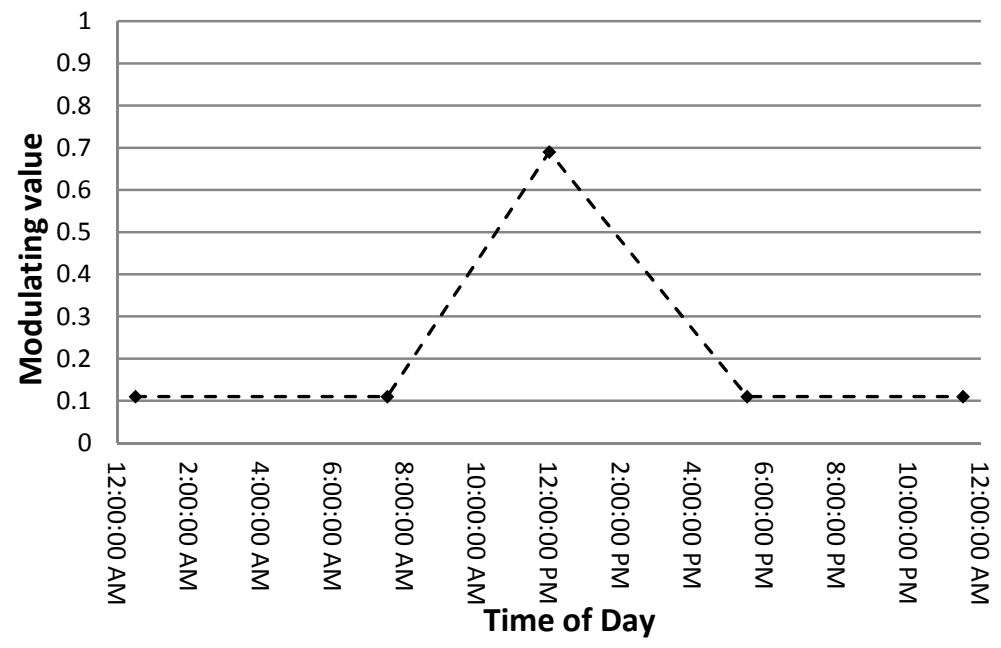

Figure 5: Transpiration profile for typical day in January

The level of transpiration chosen by this method is assumed to be an average of the plants' lifecycle - as seedlings tend to transpire less than mature plants, which transpire more before harvest than after therefore the greenhouse will contain plants at all stages. Evaporation from the media growing the plants was assumed to be negligible, as in hydroponic setups with minimal openings from the water circulation channels (where the roots sit) to the environment.

In a warm climate, like the Mediterranean, where the greenhouse interior climate is more closely coupled to the exterior environment, because of natural ventilation/open windows etc., Boulard \& Wang (2000) note how previously developed models for a moderate climate do not stand up. Because of the level of natural ventilation required in this simulated greenhouse, the Mediterranean climate model may more accurately represent the warm season in Toronto. The level of information needed to create a model using Mediterranean data was not available, so a comparison could not be made. The development of a comprehensive Toronto-based plant transpiration model will be an important improvement for future research.

\subsubsection{Supplementary lighting model}

A model for lighting was also created, specifically high pressure sodium (HPS) lights, which are typically used in greenhouses for lighting in times of low sunlight to maintain plant photosynthesis. HPS lights may provide $15-41 \%$ of the heating requirement of a greenhouse, although it is a very inefficient method of heating (Gomez, Morrow, Bourget, Massa, \& Mitchell, 2013). Therefore this lighting, used primarily in the heating season (September-April), is treated as a sensible heat gain. 
The schedule was developed to begin extending the day length in September, based specifically on sunrise and sunset times for Toronto, to achieve 17 hours of light for the plants in the greenhouse. The period when the lights are on continues to lengthen (based, again, on sunrise and sunset) until they are on for the full 17 hours between December and February. For March and April, they are off at midday and only extend day length as in September-November (Boulianne, 2011). Another method for controlling supplementary light in the greenhouse is to have it come on when a specific low light level is achieved in the greenhouse. This system involves more sophisticated controls, but may conserve energy, since lights are only on when absolutely necessary, while maintaining appropriate light levels for crops in the greenhouse (L. Rathmell, personal communication, June 12, 2013). Alternative supplementary lighting control is therefore important for future research.

The target for supplementary irradiance is $8-15 \mathrm{~W} / \mathrm{m}^{2}$ for HPS lights on tomatoes/cucumbers (Aldrich \& Bartok, 1994; Argus Controls, 2010). For the purposes of this lighting model, an average of $10 \mathrm{~W} / \mathrm{m}^{2}$ was taken ( $\approx 6700$ lux). It was assumed that $75 \%$ of the floor area will be planted and therefore require lighting.

The number of fixtures, N, required for the area was determined using the following formula (Aldrich \& Bartok, 1994):

$$
N=\frac{\text { light level } \times \text { surface area }}{\text { effective flux }}=\frac{6700 \mathrm{lux} \times 986 \mathrm{~m}^{2} \times 0.75}{117 \mathrm{lum} / \mathrm{W} \times 400 \mathrm{~W}}=105
$$

Alternatively, the Government of Alberta in a greenhouse construction guide recommends rows of lights spaced at $3.6 \mathrm{~m}$, with lights every $2.7 \mathrm{~m}$ along the rows, for a conservative total of 81 fixtures over the greenhouse area (Calpas, 2003). This aligns well with assumptions above.

Therefore 105 fixtures, for a typical $400 \mathrm{~W}$ fixture, over $986 \mathrm{~m}^{2}$ sets the power consumption at $43 \mathrm{~W} / \mathrm{m}^{2}$. Of that power input, approximately $70 \%$ is converted to heat (Gomez et al., 2013), yielding a total sensible gain of $30 \mathrm{~W} / \mathrm{m}^{2}$ - therefore the sensible heat gain when the lighting is turned on is set to be $30 \mathrm{~W} / \mathrm{m}^{2}$ in the simulation model.

For every other variable, the greenhouse is setup with only moderate internal loads. The greenhouse will act as a simple buffer zone on the top level of the office building. It was decided that this interior loading is sufficient to give results for possible benefits to the heating and cooling loads of the office 
building and greenhouse, and their respective environments, while also removing the possibility of inaccuracies in these rudimentary ET and HPS lighting models.

\subsubsection{Baseline results}

As described above, both the office and the greenhouse were assigned baseline configurations: typical insulation levels of $5.28 \mathrm{~m}^{2} \mathrm{~K} / \mathrm{W}$ in the office roof and $2.64 \mathrm{~m}^{2} \mathrm{~K} / \mathrm{W}$ in the greenhouse slab, a single glazed no coating greenhouse envelope, and moderate internal loads, in addition to unchanging temperature setpoints and other construction/system information.

As an initial comparison, the office building was modelled alone at its baseline, and then checked against the average Canadian office building energy consumption given by BOMA: $394 \mathrm{kWh} / \mathrm{m}^{2} \mathrm{yr}$ (BOMA Canada, 2011). The greenhouse was also modelled separately as a standalone structure. In the final model, the greenhouse was stacked on the office building for the building-integrated simulations (Figure $6)$.
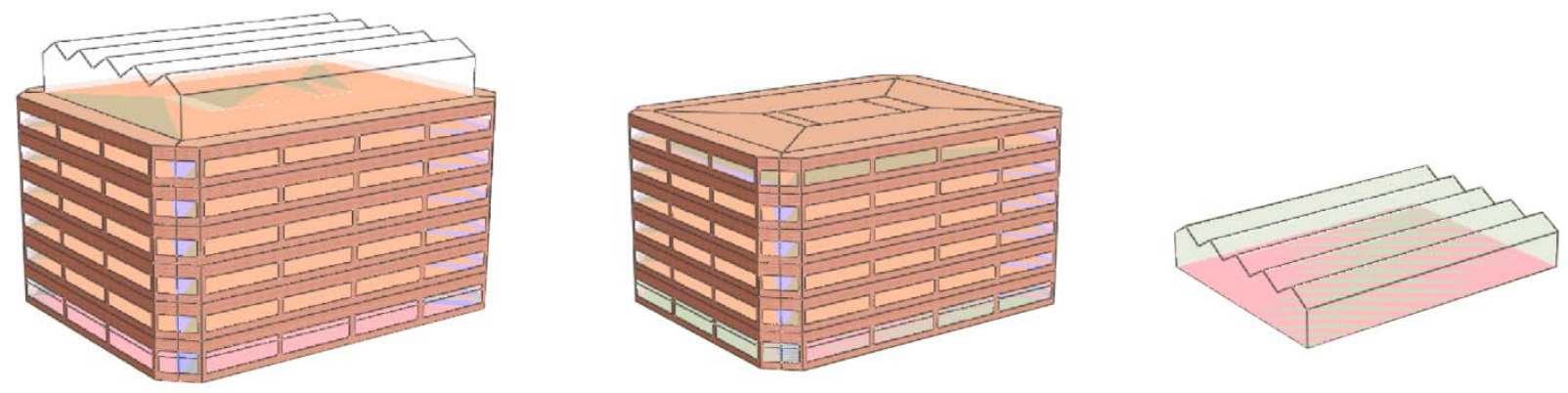

Figure 6: Building-integrated vs. standalone office and greenhouse IES simulation models

Through all simulations, nothing about the office building or greenhouse changed except for the variable in question. After each variable was changed, the HVAC system was auto-sized by the program for maximum energy efficiency. Finally, a full simulation was run, for a one year period, with data collection intervals every 10 minutes.

The temperature in the office and greenhouse were checked each time to ensure they remained within limits acceptable for plant growth (both temperature and relative humidity) and human occupancy, although when it was not possible the results were noted. The maximum and minimum temperatures in the greenhouse were collected after each simulation as another comparison of the effect of each variable. 
Then the heating and cooling energy of the office building and the greenhouse were analyzed both separately, and as an overall energy consumption; both as standalone (SA) structures and as two halves of a building-integrated (BI) system (as shown above in Figure 6). Comparisons between the SA structures allow for an evaluation of which structure benefits most from the connection through each variable tested. Comparisons of the $\mathrm{BI}$ energy consumption for heating and cooling over each simulation indicate whether there is an overall benefit to the symbiosis, and help predict what variables may be most appropriate for future rooftop greenhouses and their host buildings.

A comparison of energy savings between simulations was conducted based on trends in the results. Any percentages assigned to savings do not represent absolute numbers, but are used as a tool to assess the magnitude of the trend, allowing that an unknown margin of error exists between the simulation model and real world settings.

\subsection{Variables}

\subsubsection{Roof insulation}

For this variable, both the SA office building roof insulation, and the level of insulation between the office and rooftop greenhouse were increased in each simulation by $1.76 \mathrm{~m}^{2} \mathrm{~K} / \mathrm{W}$ from no insulation. In total, they are tested at RSI $0,0.88,1.76,3.52,5.28,7.04,8.81$ and $10.6 \mathrm{~m}^{2} \mathrm{~K} / \mathrm{W}$ for a total of eight iterations each, where RSI $5.28 \mathrm{~m}^{2} \mathrm{~K} / \mathrm{W}$ is considered the baseline for the office building roof (recommendation from ASHRAE AEDG for Small to Medium Office Buildings). The roof assembly is described in Table 3 (note: the specific heat capacities are given per unit weight, not volume). The underslab greenhouse insulation is similarly tested. The baseline for the greenhouse slab is set at RSI $2.64 \mathrm{~m}^{2} \mathrm{~K} / \mathrm{W}$ and is therefore a ninth iteration in the case of the SA greenhouse including all the values listed above.

Table 3: Office building roof assembly for standalone and building integrated simulations

\begin{tabular}{|l|r|r|r|r|}
\hline Material (outside to inside) & $\begin{array}{l}\text { Specific heat } \\
\text { capacity }(\mathbf{J} / \mathbf{k g} \cdot \mathbf{K}))\end{array}$ & $\begin{array}{l}\text { Conductivity } \\
(\mathbf{W} /(\mathbf{m} \cdot \mathbf{k}))\end{array}$ & Density $\left(\mathbf{k g} / \mathbf{m}^{\mathbf{3}}\right)$ & Thickness $(\mathbf{m})$ \\
\hline $\begin{array}{l}\text { [RFIN] Description: ROOF INSULATION (ASHRAE) } \\
\text { R-30 }\end{array}$ & 837.4 & 0.018 & 16.018 & 0.095 \\
\hline$[$ CCD] Description: CAST CONCRETE (DENSE) & 840 & 1.4 & 2100 & 0.1 \\
\hline$[$ MD] Description: Metal Deck (ASHRAE) & 896 & 160 & 2800 & 0.01 \\
\hline
\end{tabular}

In the $\mathrm{BI}$ scenario, the changing levels of insulation affect only the area common to the rooftop greenhouse and the office building, i.e. the greenhouse footprint. For consistency, this area of changing insulation remains the same when testing the SA office building, even though a rooftop greenhouse is 
not present. The perimeter of the office roof remains at the baseline in all simulations (RSI $5.28 \mathrm{~m}^{2} \mathrm{~K} / \mathrm{W}$ ) in order to avoid mixing results with widely varied levels of insulation exposed to external conditions (Figure 7). Depending on the results, the roof would have to be carefully detailed to reflect different levels of insulation in the greenhouse footprint vs. the perimeter. Future work may also investigate what level of insulation would be most beneficial when changing the entire roof, instead of only the greenhouse footprint.

For clarification, the area common to the rooftop greenhouse and office building will be referred to as the greenhouse footprint. As mentioned above, all simulations are run with baseline constructions, systems and setpoints, changing only the insulation variable.

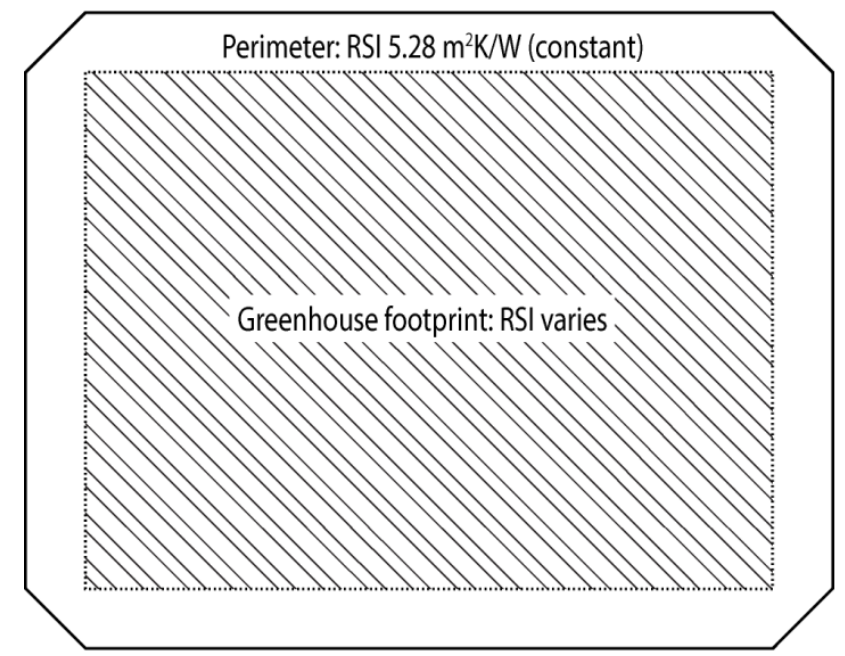

Figure 7: Office roof plan showing area of changing insulation for standalone and building integrated simulations

The results were analyzed to determine what level of insulation is most beneficial to the office building, the greenhouse, and the system (office + greenhouse), i.e. offers the lowest annual heating and cooling energy consumption.

\subsubsection{Thermal mass}

Thermal mass was incorporated into the greenhouse for load shedding by modifying the roof assembly of the office building so that the concrete layer was exposed to the rooftop greenhouse (Table 4). The flipped assembly was tested with the same levels of insulation as in the previous roof insulation simulations, except placed below the concrete slab. 
HEATING AND COOLING REQUIREMENT OF AN OFFICE BUILDING AND URBAN ROOFTOP GREENHOUSE

Table 4: Office building roof assembly with thermal mass in greenhouse for standalone and building integrated simulations

\begin{tabular}{|c|c|c|c|c|}
\hline Material (outside to inside) & $\begin{array}{l}\text { Specific heat } \\
\text { capacity }(\mathrm{J} /(\mathrm{kg} \cdot \mathrm{K}))\end{array}$ & $\begin{array}{l}\text { Conductivity } \\
(\mathrm{W} /(\mathrm{m} \cdot \mathrm{K}))\end{array}$ & Density $\left(\mathrm{kg} / \mathrm{m}^{3}\right)$ & Thickness (m) \\
\hline [CCD] Description: CAST CONCRETE (DENSE) & 840 & 1.4 & 2100 & 0.1 \\
\hline [MD] Description: Metal Deck (ASHRAE) & 896 & 160 & 2800 & 0.01 \\
\hline $\begin{array}{l}\text { [RFIN] Description: ROOF INSULATION (ASHRAE) } \\
\text { R-30 }\end{array}$ & 837.4 & 0.018 & 16.018 & 0.095 \\
\hline
\end{tabular}

To provide extra evidence for the effect of thermal mass on the greenhouse, the concrete in the $\mathrm{BI}$ separation was replaced entirely with a thin layer of insulation having an equivalent thermal resistance, but a negligible thermal mass. This was tested alongside RSI $5.28 \mathrm{~m}^{2} \mathrm{~K} / \mathrm{W}$, as well as no additional insulation. Secondly, the layer of concrete in the separation was doubled, and also tested with RSI 5.28 $\mathrm{m}^{2} \mathrm{~K} / \mathrm{W}$, and no insulation. As before in the roof insulation simulations, the only area being modified is the footprint of the greenhouse, unless specifically mentioned otherwise.

The SA greenhouse from the first round of simulations already had its thermal mass facing the space, since the insulation was underslab. Therefore, here, it was retested using over-slab insulation to explore the difference in the SA greenhouse of having thermal mass. Similarly, the office building was tested with RSI $5.28 \mathrm{~m}^{2} \mathrm{~K} / \mathrm{W}$ insulation in the roof, flipped so that the concrete layer was to the exterior, externalizing the thermal mass.

\subsubsection{Greenhouse envelope}

The greenhouse envelope was tested in several stages; first by modifying the glass from single pane to double pane, increasing the thermal resistance of the envelope. Simulations were also run with low emissivity reflective coatings, and double glazing to observe the effect that their insulative properties have on the energy requirement of the system, while noting the effect that the new conditions (such as a decrease in visible transmittance) may have on plant growth. Additionally, adding a thermal reflective night curtain was explored as another modification to the greenhouse envelope.

Using the baseline single pane greenhouse glazing to begin, a low-emissivity coating was chosen. The double pane glass is simply two layers of the single pane, with a $9.5 \mathrm{~mm}$ airspace; a low-e coating is added on the second surface, with an emissivity of 0.18 . As recommended by the technical department at Guardian Glass, LBNL Window 6 software was used to obtain the established properties of the glass assemblies for their products for the remaining glazing types. The vision area remains the same in every simulation.

The results are compiled in Table 5. 
Table 5: Properties of greenhouse glazing assemblies

\begin{tabular}{|c|c|c|c|c|c|c|c|}
\hline Glazing type & $\begin{array}{l}\text { (outside } \mathrm{L}, \\
\text { inside } \mathrm{R} \text { ) }\end{array}$ & $\begin{array}{l}\text { Thickness } \\
\text { (mm) }\end{array}$ & Tilt & $\begin{array}{l}\text { U-value } \\
\text { (COG) }\end{array}$ & $\begin{array}{c}\begin{array}{c}\text { Solar heat } \\
\text { gain } \\
\text { coefficient }\end{array} \\
\end{array}$ & $\begin{array}{c}\text { Visible } \\
\text { Transmittance }\end{array}$ & Shading Coefficient \\
\hline \multirow{3}{*}{$\begin{array}{c}\text { Single pane } \\
\text { tempered glass, } \\
4 \mathrm{~mm}\end{array}$} & & \multirow[t]{2}{*}{3.8354} & 90 & 5.88422 & 0.862536 & 0.89935 & 0.991421 \\
\hline & & & 30 & 6.691795 & 0.864325 & 0.89935 & 0.993477 \\
\hline & & \multirow{3}{*}{3.8354} & & & & & \\
\hline \multirow{2}{*}{$\begin{array}{l}\text { Single pane, } \\
\text { low-e coating }\end{array}$} & & & 90 & 3.824808 & 0.781758 & 0.872798 & 0.898572 \\
\hline & & & 30 & 4.833783 & 0.786605 & 0.872798 & 0.904143 \\
\hline \multirow{4}{*}{$\begin{array}{l}\text { Double pane } \\
\text { tempered glass, } \\
\text { air filled }\end{array}$} & \multirow{3}{*}{$\begin{array}{l}88 \\
88 \\
88 \\
8\end{array}$} & \multirow{4}{*}{$\begin{array}{c}17.1708 \\
(3.8+9.5+3.8)\end{array}$} & 90 & 2.838514 & 0.765399 & 0.814488 & 0.879769 \\
\hline & & & & & & & 0 0०ว०น \\
\hline & & & 30 & 3.061595 & 0.767376 & 0.814488 & 0.882041 \\
\hline & & & & & & & \\
\hline \multirow{3}{*}{$\begin{array}{l}\text { Double pane, } \\
\text { air filled, low-e } \\
\text { coating }\end{array}$} & \multirow{3}{*}{288} & \multirow{3}{*}{$\begin{array}{c}17.1708 \\
(3.8+9.5+3.8)\end{array}$} & 90 & 2.116202 & 0.702294 & 0.791071 & 0.807235 \\
\hline & & & 30 & 2.422876 & 0.70377 & 0.791071 & 0.808931 \\
\hline & & & & & & & \\
\hline
\end{tabular}

Each different glazing type was tested with the baseline insulation level, followed by no insulation in the BI separation, and SA greenhouse slab (Figure 8), and analyzed in comparison with baseline SA simulations to find the most efficient greenhouse envelope.

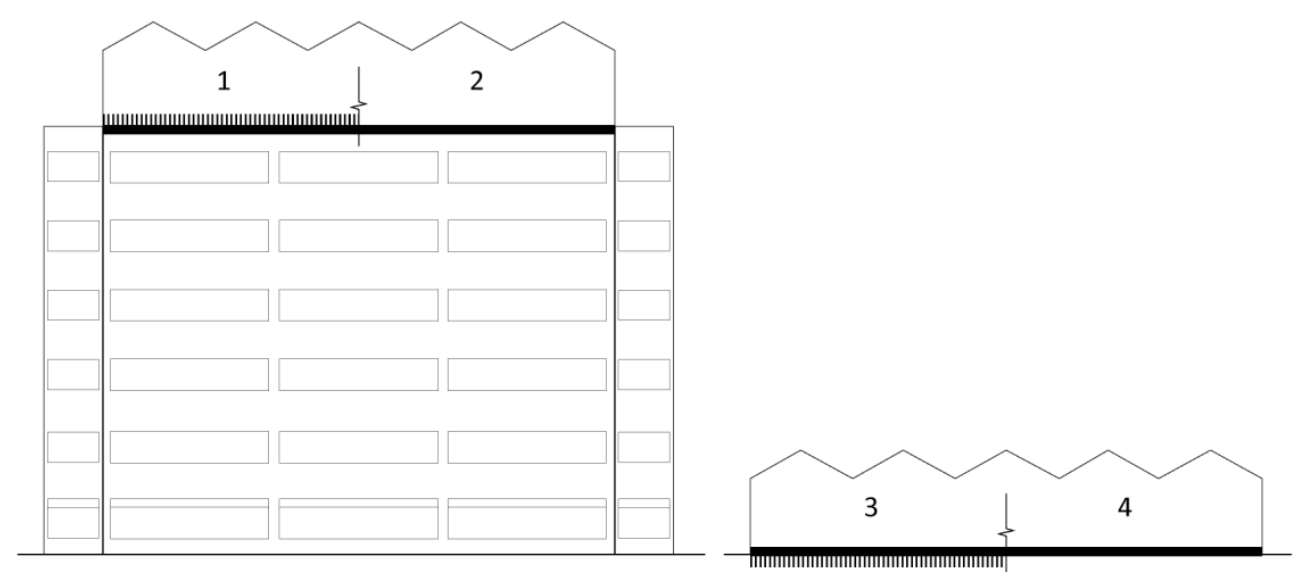

Figure 8: Insulation level scenarios for greenhouse glazing and ET/HPS lights

Another method of analysis for specific simulations involved taking temperature readings on either side of the roof assembly (Figure 9) that were converted into a heat flux using the following equation (Yu, Gao, \& Gong, 2010): 


$$
Q_{r}=U\left(T_{o}-T_{i}\right)
$$

Where,

$$
\begin{aligned}
& Q_{r}=\text { heat flux through the roof }\left(\mathrm{W} / \mathrm{m}^{2}\right) \\
& \mathrm{U}=\text { overall heat transfer coefficient }\left(\mathrm{W} / \mathrm{m}^{2} \cdot \mathrm{K}\right) \text { (changes with varying levels of insulation) } \\
& \mathrm{T}_{\mathrm{o}}=\text { outdoor surface temperature, or greenhouse temperature } \\
& \mathrm{T}_{\mathrm{i}}=\text { indoor surface temperature }
\end{aligned}
$$

A positive value indicates heat flow from the exterior to the interior of the office building, while a negative value indicates the opposite. This provides another reference point to help determine and describe the mechanism by which some results are influenced.

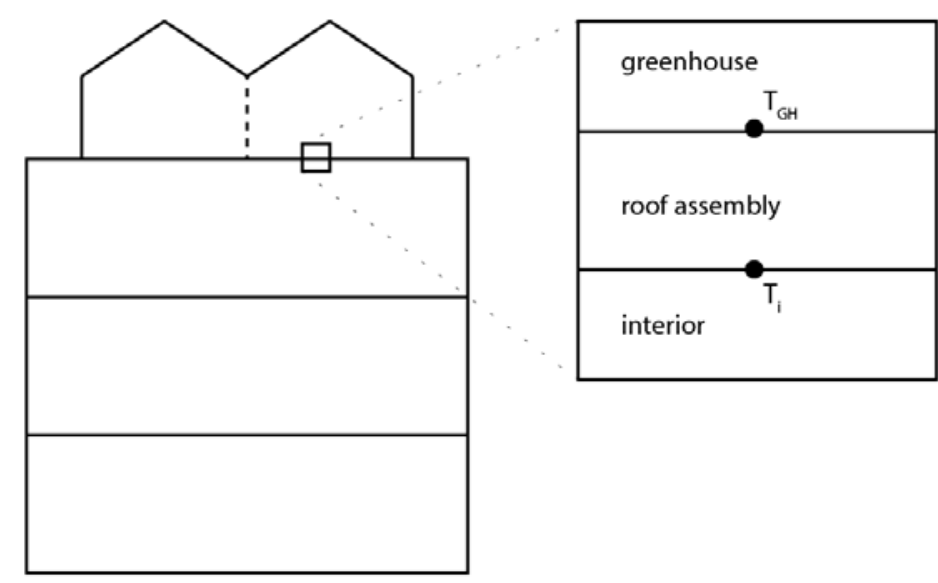

Figure 9: Schematic of temperature readings for calculating heat flux between office and greenhouse

\subsubsection{Evapotranspiration and high pressure sodium lights}

After developing these models, the greenhouse was tested with three different interior load setups.

First, it was given moderate lighting, equipment and occupancy loads. Next, the evapotranspiration (ET) model was input in the model as a latent load that turns on and off based on plant transpiration rates. The latent load of ET was added in addition to the initial moderate lighting/equipment interior loading.

Finally, the model for high pressure sodium (HPS) crop lights was added, representing a sensible heat load when the lights are turned on, as the lights can provide $15-41 \%$ of the heating load of a greenhouse (Gomez et al., 2013). The sensible load of HPS lights was added to both the initial moderate internal loads and ET.

All three sets of internal loads were tested in a SA greenhouse with baseline (RSI $2.64 \mathrm{~m}^{2} \mathrm{~K} / \mathrm{W}$ ) underslab insulation and no insulation, and a BI baseline system with RSI $5.28 \mathrm{~m}^{2} \mathrm{~K} / \mathrm{W}$ insulation in the separation 
and no insulation (equivalent to Figure 8 above). After the thermal mass simulations had been completed, it was decided to add a third scenario, so the three sets of internal loads were also tested in a SA greenhouse with insulation over the slab to eliminate the benefit of thermal mass in the greenhouse.

The models including ET loads were scrutinized based on the cooling energy consumption of the greenhouse and office building vs. the moderate loads calculated previously. This helps to ascertain whether an evaporative cooling effect results from plant ET that could influence the office building when the greenhouse is building integrated, as green roofs have been shown to be in other studies (Jaffal et al., 2012; Niachou et al., 2001).

\subsubsection{Summary of Simulations}

Table 6: Summary of all simulations

\begin{tabular}{|c|c|c|c|c|c|c|c|c|c|c|}
\hline Insulation level (RSI, $\mathrm{m}^{2} \mathrm{~K} / \mathrm{W}$ ) & & 0 & 0.88 & 1.76 & 2.64 & 3.52 & 5.28 & 7.04 & 8.81 & 10.6 \\
\hline \multicolumn{11}{|l|}{ Roof insulation simulation runs } \\
\hline BI greenhouse & $\begin{array}{l}\text { Insulation in separation, above } \\
\text { concrete deck }\end{array}$ & $\bullet$ & - & - & & - & - & - & - & - \\
\hline SA greenhouse & Insulation underslab & $\bullet$ & - & - & $\bullet$ & - & • & - & • & • \\
\hline SA office & $\begin{array}{l}\text { Roof insulation, above concrete } \\
\text { deck }\end{array}$ & $\bullet$ & - & - & & - & - & - & - & - \\
\hline \multicolumn{11}{|l|}{ Thermal mass simulation runs } \\
\hline \multirow[t]{3}{*}{ BI greenhouse } & $\begin{array}{l}\text { Insulation in separation, below } \\
\text { concrete deck }\end{array}$ & - & - & - & & - & • & - & - & - \\
\hline & $\begin{array}{l}\text { Equivalent insulation (no } \\
\text { thermal mass) }\end{array}$ & $\bullet$ & & & & & - & & & \\
\hline & Double concrete layer & • & & & & & $\bullet$ & & & \\
\hline SA greenhouse & $\begin{array}{l}\text { Insulation overslab, covering up } \\
\text { thermal mass }\end{array}$ & - & - & - & - & - & - & - & - & - \\
\hline SA office & $\begin{array}{l}\text { Roof insulation, below concrete } \\
\text { deck }\end{array}$ & & & & & & - & & & \\
\hline
\end{tabular}

\begin{tabular}{|l|r|r|r|r|r|}
\hline \multicolumn{2}{|l|}{ Envelope treatment } & \multicolumn{1}{|l|}{ single } & $\begin{array}{l}\text { single } \\
\text { low-e }\end{array}$ & double & $\begin{array}{l}\text { double } \\
\text { low-e }\end{array}$ \\
\hline Greenhouse envelope \\
\hline BI greenhouse & 5.28 & $\bullet$ & $\bullet$ & $\bullet$ & $\bullet$ \\
\cline { 2 - 6 } & 0 & $\bullet$ & $\bullet$ & $\bullet$ & $\bullet$ \\
\hline SA greenhouse & 2.64 & $\bullet$ & $\bullet$ & $\bullet$ & $\bullet$ \\
\cline { 2 - 6 } & 0 & $\bullet$ & $\bullet$ & $\bullet$ & $\bullet$ \\
\hline
\end{tabular}

\begin{tabular}{|l|r|l|r|r|}
\hline \multicolumn{7}{|l|}{ Internal gains } & $\begin{array}{l}\text { moderate } \\
\text { load }\end{array}$ & latent load & $\begin{array}{l}\text { latent + } \\
\text { lights }\end{array}$ \\
\hline \multicolumn{7}{|l|}{ ET and HPS lights } \\
\hline BI greenhouse & 5.28 & $\bullet$ & $\bullet$ & $\bullet$ \\
\hline & 0 & $\bullet$ & $\bullet$ & $\bullet$ \\
\hline SA greenhouse & 2.64 & $\bullet$ & $\bullet$ & $\bullet$ \\
\hline & 0 & $\bullet$ & $\bullet$ & $\bullet$ \\
\hline
\end{tabular}




\section{Results and Analysis}

\subsection{Baseline Results}

The BI scenarios are considered as if they are built together at the same time, not as a retrofit rooftop greenhouse, i.e. the HVAC system is sized appropriately for every scenario.

The intent to compare the energy consumption of the baseline model to the Canadian national average for office buildings in order to calibrate the computer simulation model has been found to be inappropriate for several reasons. First, some office buildings included in the Canadian data set include data centres and other amenities, which are large energy consumers. Perhaps for this reason, BOMA Canada reports that small office buildings (under $9,290 \mathrm{~m}^{2}$, or $100,000 \mathrm{ft}^{2}$ ) tend to perform on average $18 \%$ better than larger office buildings (BOMA Canada, 2011). Additionally, the simulation model was designed to meet the ASHRAE AEDG for Small to Medium Office Buildings (American Society of Heating, Refrigerating and Air-Conditioning Engineers, 2011), which means that its energy consumption should already be better than average. The energy modelling software shows that the energy consumption of the current simulated six storey detached office building is only $200 \mathrm{kWh} / \mathrm{m}^{2}$ annually, as compared with the Canadian average of $392 \mathrm{kWh} / \mathrm{m}^{2}$. However the Canadian average represents all existing office buildings in Canada, not all of which comply with the more stringent building and energy codes of today. The energy use in the current simulation falls into the best performing quartile of BOMA best buildings, which consume between 110-225 kWh/m² annually (BOMA Canada, 2011).

Moreover, a relative validation was achieved through collaboration with two energy modelling professionals who pointed out errors, and suggested ways to change the model to better represent reality. Therefore, while the model may still suffer from a level of inaccuracy without having been calibrated to measured data from an existing building, it has achieved a level of precision that can with confidence be used to generate relative comparisons between different variables pertaining to a rooftop greenhouse. Although these comparisons will not give absolute numerical results, they are expected to show a positive or negative effect and ascribe an order of magnitude to any changes observed to heating and cooling requirements when variables are modified.

The modelled office building, to ASHRAE AEDG for Small to Medium Office Buildings standards, gave the following outputs (Table 7): 
HEATING AND COOLING REQUIREMENT OF AN OFFICE BUILDING AND URBAN ROOFTOP GREENHOUSE

Table 7: Baseline standalone office annual energy results

\begin{tabular}{|c|c|c|c|c|c|c|c|c|c|c|c|}
\hline Fuel type & $\begin{array}{c}\text { Space } \\
\text { Heating } \\
\text { Fossil } \\
\text { Fuel } \\
\text { kWh }\end{array}$ & $\begin{array}{c}\text { Space } \\
\text { Cooling } \\
\text { Electricity } \\
\text { kWh }\end{array}$ & $\begin{array}{c}\text { Pumps } \\
\text { Electricity } \\
\text { kWh }\end{array}$ & $\begin{array}{c}\text { Heat } \\
\text { Rejection } \\
\text { Electricity } \\
\text { kWh }\end{array}$ & $\begin{array}{c}\text { Fans } \\
\text { Interior } \\
\text { Electricity } \\
\text { kWh }\end{array}$ & $\begin{array}{c}\text { Internal } \\
\text { Lighting } \\
\text { Electricity } \\
\text { kWh }\end{array}$ & $\begin{array}{c}\text { Service } \\
\text { Water } \\
\text { Heating } \\
\text { Fossil } \\
\text { Fuel } \\
\text { kWh }\end{array}$ & $\begin{array}{c}\text { Receptacle } \\
\text { Equipment } \\
\text { Electricity } \\
\text { kWh }\end{array}$ & $\begin{array}{c}\text { Elevators } \\
\text { Escalators } \\
\text { Electricity } \\
\text { kWh }\end{array}$ & $\begin{array}{l}\text { Total } \\
\text { kWh }\end{array}$ & $\begin{array}{l}\text { Total } \\
\text { kWh/m }{ }^{2} \\
\text { gross }\end{array}$ \\
\hline Electricity & 0 & 48,020 & 10,144 & 30,059 & 55,043 & 283,292 & 0 & 319,414 & 175,200 & 921,171 & 110.08 \\
\hline $\begin{array}{l}\text { Fossil } \\
\text { Fuels } \\
\end{array}$ & 721,671 & 0 & 0 & 0 & 0 & 0 & 24,694 & 0 & 0 & 746,366 & 89.19 \\
\hline Totals & 721,671 & 48,020 & 10,144 & 30,059 & 55,043 & 283,292 & 24,694 & 319,414 & 175,200 & $1,667,537$ & 199.27 \\
\hline
\end{tabular}

The results used to compare different simulations are specifically the annual space heating and space cooling energy. For the office, the heating energy is annual energy drawn by the boilers, and cooling is chiller energy, as highlighted in red (Table 7).

For the greenhouse, the heating energy represents boilers (see Greenhouse baseline design, p. 13). In the simulations where HPS supplementary lighting is included, $70 \%$ of the supplementary lighting energy (based on the estimated efficiency of the light source) is included in heating energy. The cooling energy for the greenhouse is considered to be the energy of ventilation, i.e. fans. No other energy use is reported in the results, including auxiliary HVAC equipment (pumps, fans), lighting, equipment etc.; only the heating and cooling energy highlighted in red.

Greenhouses typically use between $315.4-788.7 \mathrm{kWh} / \mathrm{m}^{2}\left(100000-250000 \mathrm{Btu} / \mathrm{ft}^{2}\right)$ to maintain temperatures in the heating season, and 3.59-10.76 kWh $/ \mathrm{m}^{2}\left(1 / 3-1 \mathrm{Btu} / \mathrm{ft}^{2}\right)$ over the cooling season (Aldrich \& Bartok, 1994). The SA greenhouse with a typical level of underslab insulation (RSI 2.64 $\mathrm{m}^{2} \mathrm{~K} / \mathrm{W}$ ), and minimal interior loads uses $787.9 \mathrm{kWh} / \mathrm{m}^{2}$ for heating, and $4.94 \mathrm{kWh} / \mathrm{m}^{2}$ for ventilation, as determined from the information in Table 8 and the greenhouse footprint of $986.4 \mathrm{~m}^{2}$. Therefore the greenhouse simulation model heating and cooling (i.e. ventilation) energy is within the limits of a typical greenhouse.

However, even with maximum ventilation the greenhouse still reaches temperatures up to $38^{\circ} \mathrm{C}$ many times throughout the summer, for hours at a time. Even when manually changing the fan capacity to $20000 \mathrm{~L} / \mathrm{s}$ (4 times auto-sized capacity), very little change is observed in the peak temperature; the greenhouse is cooler for a slightly longer period, and the fan energy is increased greatly. Therefore it appears as though ventilation is not enough to keep the greenhouse cool year round in the Toronto climate; further research into climate-appropriate cooling systems for Toronto is required. With the 
addition of a dedicated cooling system in the greenhouse, the ventilation load would likely decrease, and the cooling energy would be very different, based on a different method of cooling other than fans.

The results from the baseline standalone greenhouse are demonstrated in Table 8:

\begin{tabular}{|c|c|c|c|c|c|c|}
\hline Fuel type & $\begin{array}{c}\begin{array}{c}\text { Space } \\
\text { Heating }\end{array} \\
\text { Electricity } \\
\text { kWh }\end{array}$ & $\begin{array}{c}\text { Ventilation } \\
\text { fans } \\
\text { Electricity } \\
\text { kWh }\end{array}$ & $\begin{array}{c}\text { Internal } \\
\text { Lighting } \\
\text { Electricity } \\
\text { kWh }\end{array}$ & $\begin{array}{c}\text { Receptacle } \\
\text { Equipment } \\
\text { Electricity } \\
\text { kWh }\end{array}$ & $\begin{array}{l}\text { Total } \\
\text { kWh }\end{array}$ & $\begin{array}{l}\text { Total } \\
\text { kWh/m }{ }^{2} \\
\text { gross }\end{array}$ \\
\hline Electricity & 787,096 & 4,877 & 20,935 & 5,234 & 818,141 & 829.42 \\
\hline Fossil Fuels & 0 & 0 & 0 & 0 & 0 & 0 \\
\hline Totals & 787,096 & 4,877 & 20,935 & 5,234 & 818,141 & 829.42 \\
\hline
\end{tabular}

Baseline results for comparison with simulations below refer to sum of the heating and cooling energy requirements of the SA office building with RSI $5.28 \mathrm{~m}^{2} \mathrm{~K} / \mathrm{W}$ insulation in the roof (Table 7), and the SA greenhouse with RSI $2.64 \mathrm{~m}^{2} \mathrm{~K} / \mathrm{W}$ underslab insulation, single glazing and moderate internal loads (Table 8). This best represents the standalone structures in reality, although the configuration of insulation (above deck in the office roof, underslab for greenhouse) gives a thermal mass advantage to both SA structures. In BI scenarios, the thermal mass typically only benefits one structure, and this inequality is discussed further below.

With the baseline results established, the four variables - insulation, thermal mass, the greenhouse envelope and supplementary greenhouse lighting - were examined.

\subsection{Effect of roof insulation}

As expected, increasing levels of insulation in the SA office roof led to decreasing annual energy consumption for both heating and cooling. Similarly, increasing levels of insulation in the slab assembly of the SA greenhouse decreased heating energy, but caused an increase in the requirement for cooling, suggesting that the ground was having a moderating effect on the interior greenhouse temperature in the cooling season (Table 9).

For the $\mathrm{BI}$ system, the results show the simulation with no insulation in the greenhouse footprint as having the lowest annual heating and cooling energy of all simulations, as well as the lowest number of overheating hours (Table 9; Figure 10). Additionally, in this simulation, the maximum temperature is shown to be lower in the $\mathrm{BI}$ than the SA greenhouse while the minimum temperature is higher; this appears to be a beneficial effect of building integration. 
HEATING AND COOLING REQUIREMENT OF AN OFFICE BUILDING AND URBAN ROOFTOP GREENHOUSE

Table 9: Effect of roof insulation, overall results

\begin{tabular}{|c|c|c|c|c|c|c|c|c|c|c|}
\hline Insulation level $\left(\mathrm{m}^{2} \mathrm{~K} / \mathrm{W}\right)$ & $\begin{array}{l}\text { Annual } \\
\text { space } \\
\text { heating } \\
\text { office (kWh) }\end{array}$ & $\begin{array}{l}\text { Annual } \\
\text { space } \\
\text { cooling } \\
\text { office (kWh) }\end{array}$ & $\begin{array}{l}\text { Total office } \\
\text { (kWh) }\end{array}$ & $\begin{array}{l}\text { Annual space } \\
\text { heating } \\
\text { greenhouse } \\
\text { (kWh) }\end{array}$ & \begin{tabular}{|l} 
Annual \\
ventilation \\
greenhouse \\
(kWh) \\
\end{tabular} & $\begin{array}{l}\text { Total } \\
\text { greenhouse } \\
\text { (kWh) }\end{array}$ & $\begin{array}{l}\text { Total system } \\
(\mathrm{kWh})\end{array}$ & $\begin{array}{l}\text { Greenhouse } \\
\text { max. temp } \\
\left({ }^{\circ} \mathrm{C}\right)\end{array}$ & $\begin{array}{l}\text { Greenhouse } \\
\text { min. temp }\left({ }^{\circ} \mathrm{C}\right)\end{array}$ & $\begin{array}{l}\text { Greenhouse } \\
\text { hours above } \\
30^{\circ} \mathrm{C}\end{array}$ \\
\hline \multicolumn{11}{|c|}{ BI system, greenhouse footprint insulation } \\
\hline RSI 0 & 683,427 & 67,212 & 750,639 & 830,798 & 3,288 & 834,086 & $1,584,725$ & 35.34 & 16.91 & 306 \\
\hline RSI 0.88 & 685,645 & 50,441 & 736,086 & 874,670 & 4,780 & 879,450 & $1,615,536$ & 37.82 & 13.96 & 581 \\
\hline RSI 1.76 & 697,230 & 49,878 & 747,108 & 896,869 & 4,582 & 901,451 & $1,648,559$ & 38.15 & 13.53 & 451 \\
\hline RSI 3.52 & 687,706 & 46,851 & 734,557 & 892,538 & 4,857 & 897,395 & $1,631,952$ & 38.39 & 13.19 & 571 \\
\hline RSI 5.28 & 684,635 & 45,816 & 730,451 & 885,886 & 5,064 & 890,950 & $1,621,401$ & 38.44 & 13.05 & 635 \\
\hline RSI 7.04 & 684,251 & 45,563 & 729,814 & 884,826 & 5,114 & 889,940 & $1,619,754$ & 38.51 & 12.99 & 628 \\
\hline RSI 8.81 & 684,151 & 45,337 & 729,488 & 883,998 & 5,125 & 889,123 & $1,618,611$ & 38.53 & 12.96 & 642 \\
\hline RSI 10.6 & 684,306 & 44,955 & 729,261 & 884,070 & 5,138 & 889,208 & $1,618,469$ & 38.55 & 12.94 & 646 \\
\hline \multicolumn{11}{|c|}{ SA greenhouse, underslab insulation } \\
\hline RSI 0 & - & - & - & 879,572 & 4,051 & 883,623 & - & 36.18 & 14.64 & 331 \\
\hline RSI 0.88 & - & - & - & 820,036 & 5,002 & 825,038 & - & 36.59 & 15.61 & 412 \\
\hline RSI 1.76 & - & - & - & 799,020 & 5,154 & 804,174 & - & 36.65 & 15.99 & 433 \\
\hline RSI 2.64 & - & - & - & 787,096 & 4,877 & 791,973 & - & 36.68 & 16.08 & 438 \\
\hline RSI 3.52 & - & - & - & 782,515 & 5,235 & 787,750 & - & 36.7 & 16.28 & 443 \\
\hline RSI 5.28 & - & - & - & 776,482 & 5,311 & 781,793 & - & 36.73 & 16.3 & 450 \\
\hline RSI 7.04 & - & - & - & 772,555 & 5,379 & 777,934 & - & 36.74 & 16.44 & 451 \\
\hline RSI 8.81 & - & - & - & 769,931 & 5,362 & 775,293 & - & 36.75 & 16.47 & 452 \\
\hline RSI 10.6 & - & - & - & 768,555 & 5,384 & 773,939 & - & 36.75 & 16.5 & 454 \\
\hline \multicolumn{11}{|l|}{ SA office, roof insulation } \\
\hline RSI 0 & $1,074,619$ & 62,957 & $1,137,576$ & - & - & - & - & - & - & - \\
\hline RSI 0.88 & 785,098 & 50,390 & 835,488 & - & - & - & - & - & - & - \\
\hline RSI 1.76 & 750,595 & 49,187 & 799,782 & - & - & - & - & - & - & - \\
\hline RSI 3.52 & 728,846 & 48,294 & 777,140 & - & - & - & - & - & - & - \\
\hline RSI 5.28 & 721,671 & 48,020 & 769,691 & - & - & - & - & - & - & - \\
\hline RSI 7.04 & 716,989 & 47,964 & 764,953 & - & - & - & - & - & - & - \\
\hline RSI 8.81 & 715,616 & 47,978 & 763,594 & - & - & - & - & - & - & - \\
\hline RSI 10.6 & 713,499 & 47,971 & 761,470 & - & - & - & - & - & - & - \\
\hline
\end{tabular}


The next simulation with RSI $0.88 \mathrm{~m}^{2} \mathrm{~K} / \mathrm{W}$ insulation similarly performed at lower overall heating and cooling energy than the super-insulated separations (RSI 7.04-10.6 $\mathrm{m}^{2} \mathrm{~K} / \mathrm{W}$ ). In the following two simulations, RSI 1.76 and $3.52 \mathrm{~m}^{2} \mathrm{~K} / \mathrm{W}$ the $\mathrm{BI}$ system performed much differently, so much so that the software experienced instability both times. In the end, the only solution was to run the simulations using a much shorter time-step between calculations; 2 minutes and 6 minutes for RSI 1.76 and 3.52 $\mathrm{m}^{2} \mathrm{~K} / \mathrm{W}$ respectively, instead of the typical 10 minutes. The annual results when run at a shorter time step tend to be higher therefore the results from these two simulations are less reliable than the other six points. It remains, however, that there is a trend towards higher heating and cooling energy consumption, supported further by the simulation done at RSI $5.28 \mathrm{~m}^{2} \mathrm{~K} / \mathrm{W}$ which experienced no instability and still results in a higher energy consumption than both the lowest insulation levels, and the highest (Figure 10).

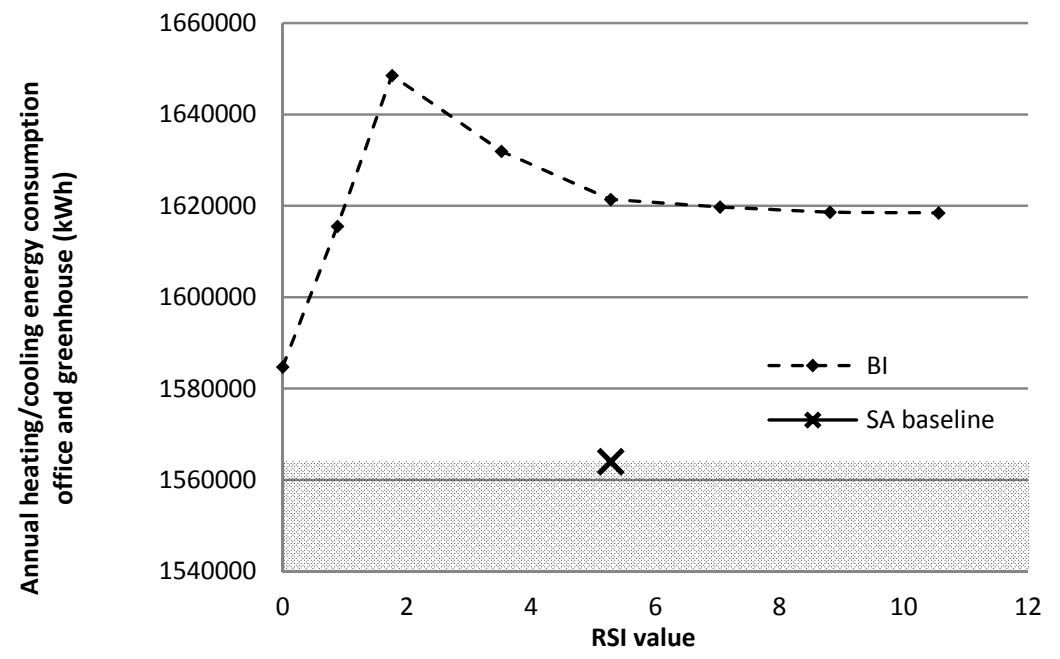

Figure 10: Effect of insulation between rooftop greenhouse and office building on the annual heating/cooling energy consumption of the BI system vs. the baseline combined SA

If discounting the simulations with 1.76 and $3.52 \mathrm{~m}^{2} \mathrm{~K} / \mathrm{W}$ insulation (because of the instability in the simulation model), the BI office building does not differ in annual heating energy by more than $1 \%$, and even including those simulations, not by more than $2 \%$ (Figure 11). This indicates that even when no insulation is present in the separation (and since the greenhouse envelope itself has little resistance), some property of the greenhouse must be providing a measure of heat, to be able to maintain the setpoint temperatures in both spaces during the heating season. This is likely due to the buffer effect as described by Swann (1996). 


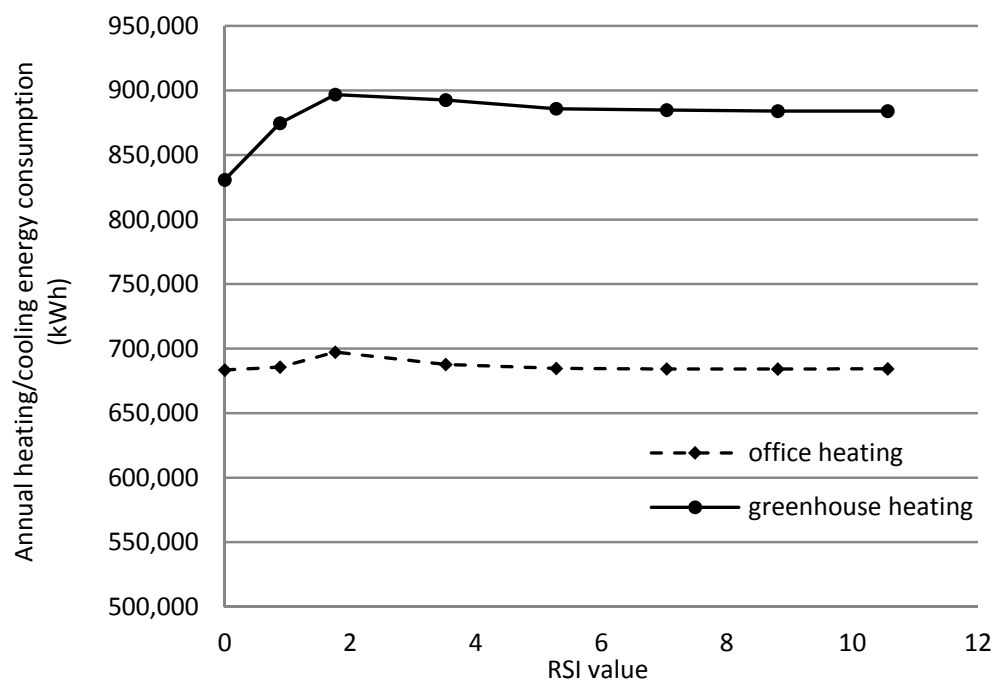

Figure 11: Effect of insulation on the annual heating energy of office vs. rooftop greenhouse in BI system

The trend in energy consumption in the greenhouse can be explained by the effect of thermal mass: the simulation with no insulation separating the greenhouse from the office building also leaves the $100 \mathrm{~mm}$ concrete roof deck exposed to the interior of the greenhouse. When RSI $0.88 \mathrm{~m}^{2} \mathrm{~K} / \mathrm{W}$ is added above the deck, the thermal resistance is still low enough that there is heat penetration into the slab, storing solar energy for colder periods and reducing the heating load in the greenhouse, though the effect is much less pronounced. This also explains the trend of increasing heating consumption in the greenhouse (as the thermal mass is covered up), which levels out with resistances higher than RSI $1.76 \mathrm{~m}^{2} \mathrm{~K} / \mathrm{W}$ in the separation. Overall, the difference between the highest BI energy consumption and the lowest is only $4 \%$, indicating thermal mass has an effect of a small magnitude. This phenomenon is discussed and tested further below (see Effect of thermal mass, page 35).

Overall, the maximum temperatures in the greenhouse appear to be higher in BI simulations than SA, and the minimum temperatures lower, which indicates the BI system needs more energy to maintain setpoint temperatures than the SA. Again, this is likely because the SA greenhouse in these simulations has the advantage of thermal mass inside the greenhouse which has a moderating effect on the temperature, while the $\mathrm{BI}$ greenhouse does not, except for the simulation with no insulation, as mentioned above. However, the level of thermal interaction with the office building makes a difference in the maximum and minimum rooftop greenhouse temperatures - the maximum temperature is $3^{\circ} \mathrm{C}$ lower when there is no insulation in the greenhouse footprint (vs. super insulated, RSI $10.6 \mathrm{~m}^{2} \mathrm{~K} / \mathrm{W}$ ), while the minimum is $4^{\circ} \mathrm{C}$ higher. 
Through the simulations from no insulation to super insulated, the BI office building annual cooling energy decreases, while the greenhouse ventilation energy increases. This suggests that as the two structures decrease in thermal connection, the office building needs less cooling in order to compensate for the additional heat provided by the greenhouse, while the greenhouse begins to require increased ventilation to maintain acceptable temperatures in the cooling season. However the cooling energy required for the office decreases in larger quantity than it increases in the greenhouse, as the insulation level is changed from nothing to RSI $10.6 \mathrm{~m}^{2} \mathrm{~K} / \mathrm{W}$. This indicates that for cooling, a higher level of thermal separation is more beneficial to the total annual cooling energy. Fundamentally, it takes more energy to cool the greenhouse with a chiller, than it does to simply replace warm air with cooler outdoor air, since the setpoint can be higher in the greenhouse than in the office building.

The difference between the highest and lowest energy consumption in the BI simulations was approximately $1 / 12$ of the difference between the highest and lowest energy SA combined systems (Table 10). The BI system is therefore not as affected by changes in insulation as the SA structures, which suggests that the integrated greenhouse and office building have a moderating effect on each other.

Therefore, out of these simulations testing the level of insulation separating the office from the rooftop greenhouse, the most beneficial symbiosis happened when there was no insulation separating the two structures (Table 10). However even this BI system with no insulation in the greenhouse footprint still performed more poorly than the baseline SA office + SA greenhouse. The comparison, as mentioned above, is not entirely equal, as the SA greenhouse benefits from the thermal mass of its concrete slab, however it is the comparison deemed closest to reality. This finding will be examined further in simulations investigating the effect of having the concrete roof layer exposed to the greenhouse, acting as thermal mass.

Table 10: Summary of the effect of roof insulation on energy consumption in SA vs. BI
\begin{tabular}{|lr|r|r|}
\hline & \multicolumn{2}{|l|}{$\begin{array}{l}\text { Total annual conditioning } \\
\text { energy (kWh) }\end{array}$} \\
\cline { 3 - 4 } & SA & BI \\
\hline No insulation & $2,021,199$ & $1,584,725$ \\
\hline Baseline insulation & $\begin{array}{r}\text { BI and SA office RSI } 5.28 \mathrm{~m}^{2} \mathrm{~K} / \mathrm{W} \\
\text { SA greenhouse RSI } 2.64 \mathrm{~m}^{2} \mathrm{~K} / \mathrm{W}\end{array}$ & $1,561,664$ & $1,621,401$ \\
\hline Super-insulated & RSI $10.6 \mathrm{~m}^{2} \mathrm{~K} / \mathrm{W}$ & $1,535,409$ & $1,618,469$ \\
\hline
\end{tabular}




\subsection{Effect of thermal mass}

Thermal mass is explored as a way of storing solar energy captured by the greenhouse during the day, to offset some of the energy required for heating at night. The greenhouse floor in these simulations was modelled as though there was no obstruction of the sunlight on the concrete thermal mass by tables/benches/equipment etc. Trends shown here would best be reproduced with as little cover on the floor of the greenhouse as possible, i.e. hanging plants, and furniture with minimum surface area contact with the ground to leave exposed as much of the thermal mass as possible. Alternatively, furniture and fixtures in the greenhouse may be designed to have a large thermal mass, or it may be incorporated otherwise (water barrels, low brick wall around the perimeter, etc.). Future study should involve the incorporation of obstructions in the greenhouse and/or other forms of thermal mass, including the effect of shading and transpiration by plants, to view how they impact the effectiveness of thermal mass.

As discussed previously, it appears from earlier simulations that thermal mass in the greenhouse is a factor in the annual heating/cooling load of the space. In the roof insulation simulations, the BI system showed lower total energy consumption when the roof assembly incorporated no insulation. Speculation suggested this result was due to the concrete thermal mass exposed to the greenhouse when no insulation was present above the deck.

It is evident from a comparison of energy consumption in the SA greenhouse with insulation over vs. under the slab-on-grade that thermal mass has a consistent effect on the heating and cooling energy required to maintain an acceptable greenhouse environment (Figure 12). 


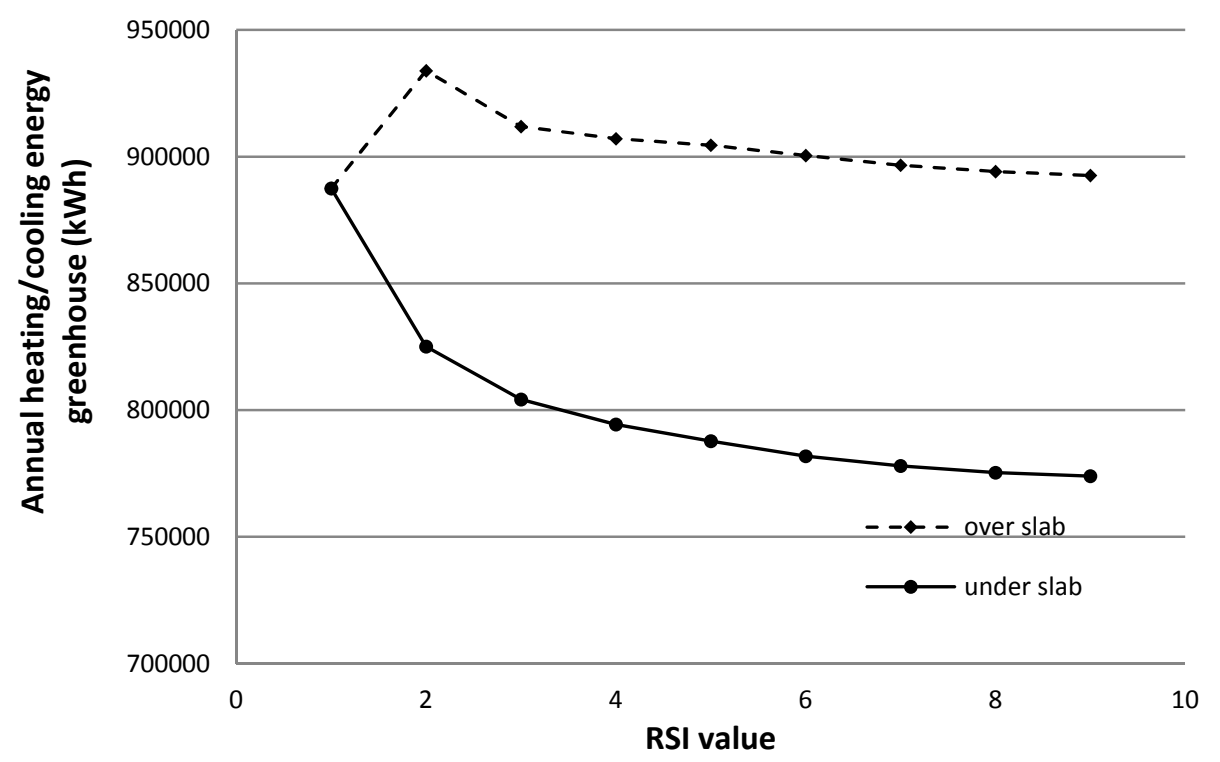

Figure 12: Annual energy required to heat and cool SA greenhouse with insulation under the slab and over

As compared with the roof insulation simulations from above, here the office building portion of the $\mathrm{BI}$ system shows a trend towards more energy for heating and cooling than it did when the insulation was entirely above deck, likely because of the loss of thermal mass in the space. This is evidenced by a simulation of the SA office building; the heating energy required is increased when the roof construction is inverted so the concrete layer is to the exterior of the insulation. However the effect is less than a $1 \%$ increase in energy consumption, which is much less than the benefit that the greenhouse receives from additional thermal mass when the concrete slab faces the interior of the greenhouse (the model indicates up to 7\%). This is likely because the greenhouse has a higher heating load to begin with because of the low resistance of its envelope, and the fact that the concrete layer in the greenhouse is directly exposed to sunlight. Therefore, overall, the BI system with thermal mass in the greenhouse uses less annual energy than the BI roof insulation simulations above (Table 11; Table 9).

N.B.: Again, the BI simulation with RSI $1.76 \mathrm{~m}^{2} \mathrm{~K} / \mathrm{W}$ insulation is unreliable because of instability in the software. 
HEATING AND COOLING REQUIREMENT OF AN OFFICE BUILDING AND URBAN ROOFTOP GREENHOUSE

Table 11: Effect of thermal mass, overall results

\begin{tabular}{|c|c|c|c|c|c|c|c|c|c|c|}
\hline $\begin{array}{l}\text { Insulation level } \\
\left(m^{2} K / W\right)\end{array}$ & $\begin{array}{l}\text { Annual } \\
\text { space } \\
\text { heating } \\
\text { office } \\
\text { (kWh) } \\
\end{array}$ & $\begin{array}{l}\text { Annual } \\
\text { space } \\
\text { cooling } \\
\text { office } \\
\text { (kWh) } \\
\end{array}$ & $\begin{array}{l}\text { Total office } \\
\text { (kWh) }\end{array}$ & $\begin{array}{l}\text { Annual space } \\
\text { heating } \\
\text { greenhouse } \\
\text { (kWh) }\end{array}$ & $\begin{array}{l}\text { Annual } \\
\text { ventilation } \\
\text { greenhouse } \\
\text { (kWh) } \\
\end{array}$ & $\begin{array}{l}\text { Total } \\
\text { greenhouse } \\
\text { (kWh) }\end{array}$ & $\begin{array}{l}\text { Total system } \\
\text { (kWh) }\end{array}$ & $\begin{array}{l}\text { Greenhouse } \\
\text { max. temp }\left({ }^{\circ} \mathrm{C}\right)\end{array}$ & $\begin{array}{l}\text { Greenhouse } \\
\text { min. temp }\left({ }^{\circ} \mathrm{C}\right)\end{array}$ & $\begin{array}{l}\text { Greenhouse } \\
\text { hours } \\
\text { above } 30^{\circ} \mathrm{C}\end{array}$ \\
\hline \multicolumn{11}{|c|}{ Bl system, greenhouse footprint insulation, thermal mass in greenhouse } \\
\hline RSI 0 & 683,427 & 67,212 & 750,639 & 830,798 & 3,288 & 834,086 & $1,584,725$ & 35.34 & 16.91 & 306 \\
\hline RSI 0.88 & 687,399 & 50,813 & 738,212 & 784,550 & 4,049 & 788,599 & $1,526,811$ & 36.02 & 16.56 & 440 \\
\hline RSI 1.76 & 703,741 & 51,412 & 755,153 & 788,428 & 4,269 & 792,697 & $1,547,850$ & 36.1 & 16.64 & 335 \\
\hline RSI 3.52 & 687,212 & 46,473 & 733,685 & 771,284 & 4,286 & 775,570 & $1,509,255$ & 36.21 & 16.53 & 470 \\
\hline RSI 5.28 & 686,809 & 45,904 & 732,713 & 769,644 & 4,309 & 773,953 & $1,506,666$ & 36.25 & 16.47 & 470 \\
\hline RSI 7.04 & 687,270 & 45,711 & 732,981 & 768,705 & 4,329 & 773,034 & $1,506,015$ & 36.27 & 16.51 & 471 \\
\hline RSI 8.81 & 687,540 & 45,450 & 732,990 & 767,869 & 4,332 & 772,201 & $1,505,191$ & 36.28 & 16.49 & 470 \\
\hline RSI 10.6 & 687,565 & 45,164 & 732,729 & 767,394 & 4,334 & 771,728 & $1,504,457$ & 36.29 & 16.49 & 474 \\
\hline $\begin{array}{l}\text { RSI 0, equivalent } \\
\text { insulation (no th.m.) }\end{array}$ & 710,635 & 72,034 & 782,669 & 883,424 & 3,798 & 887,222 & $1,669,891$ & 36.06 & 15.65 & 391 \\
\hline $\begin{array}{l}\text { RSI 0, double } \\
\text { concrete layer }\end{array}$ & 681,828 & 61,016 & 742,844 & 805,095 & 3,270 & 808,365 & $1,551,209$ & 35.24 & 17.27 & 307 \\
\hline $\begin{array}{l}\text { RSI 5.28, equivalent } \\
\text { insulation (no th.m.) }\end{array}$ & 689,640 & 46,467 & 736,107 & 883,484 & 5,095 & 888,579 & $1,624,686$ & 38.47 & 13.02 & 636 \\
\hline $\begin{array}{l}\text { RSI } 5.28 \text {, double } \\
\text { concrete layer }\end{array}$ & 686,577 & 45,778 & 732,355 & 755,860 & 3,971 & 759,831 & $1,492,186$ & 35.77 & 16.97 & 421 \\
\hline \multicolumn{11}{|c|}{ SA greenhouse, overslab insulation, covering up thermal mass (not typical) } \\
\hline RSI 0 & - & - & - & 879,572 & 4,051 & 883,623 & - & 36.18 & 14.64 & 331 \\
\hline RSI 0.88 & - & - & - & 927,912 & 5,979 & 933,891 & - & 38.67 & 12.74 & 459 \\
\hline RSI 1.76 & - & - & - & 906,327 & 5,551 & 911,878 & - & 39.04 & 12.61 & 606 \\
\hline RSI 2.64 & - & - & - & 901,464 & 5,612 & 907,076 & - & 39.18 & 12.62 & 637 \\
\hline RSI 3.52 & - & - & - & 898,871 & 5,655 & 904,526 & - & 39.26 & 12.64 & 650 \\
\hline RSI 5.28 & - & - & - & 894,751 & 5,680 & 900,431 & - & 39.33 & 12.67 & 656 \\
\hline RSI 7.04 & - & - & - & 890,952 & 5,681 & 896,633 & - & 39.36 & 12.70 & 665 \\
\hline RSI 8.81 & - & - & - & 888,416 & 5,701 & 894,117 & - & 39.37 & 12.73 & 667 \\
\hline RSI 10.6 & - & - & - & 886,869 & 5,714 & 892,583 & - & 39.37 & 12.76 & 669 \\
\hline \multicolumn{11}{|c|}{ SA office, roof insulation } \\
\hline RSI 5.28 & 721,671 & 48,020 & 769,691 & - & - & - & - & - & - & - \\
\hline $\begin{array}{l}\text { RSI } 5.28 \text {, inverted } \\
\text { roof }\end{array}$ & 729,117 & 49,308 & 778,425 & - & - & - & - & - & - & - \\
\hline
\end{tabular}


The importance of thermal mass in the greenhouse is evidenced in two additional ways; first by substituting the concrete roof slab with an equivalent level of insulation. In both examples, equivalent to the simulations with no additional insulation (therefore only a small layer of insulation representing the resistance of the concrete) and RSI $5.28 \mathrm{~m}^{2} \mathrm{~K} / \mathrm{W}$, the annual heating/cooling energy are both higher when no thermal mass is present. Conversely, when the concrete deck is doubled in thickness, the annual heating/cooling energy is decreased (Figure 13).

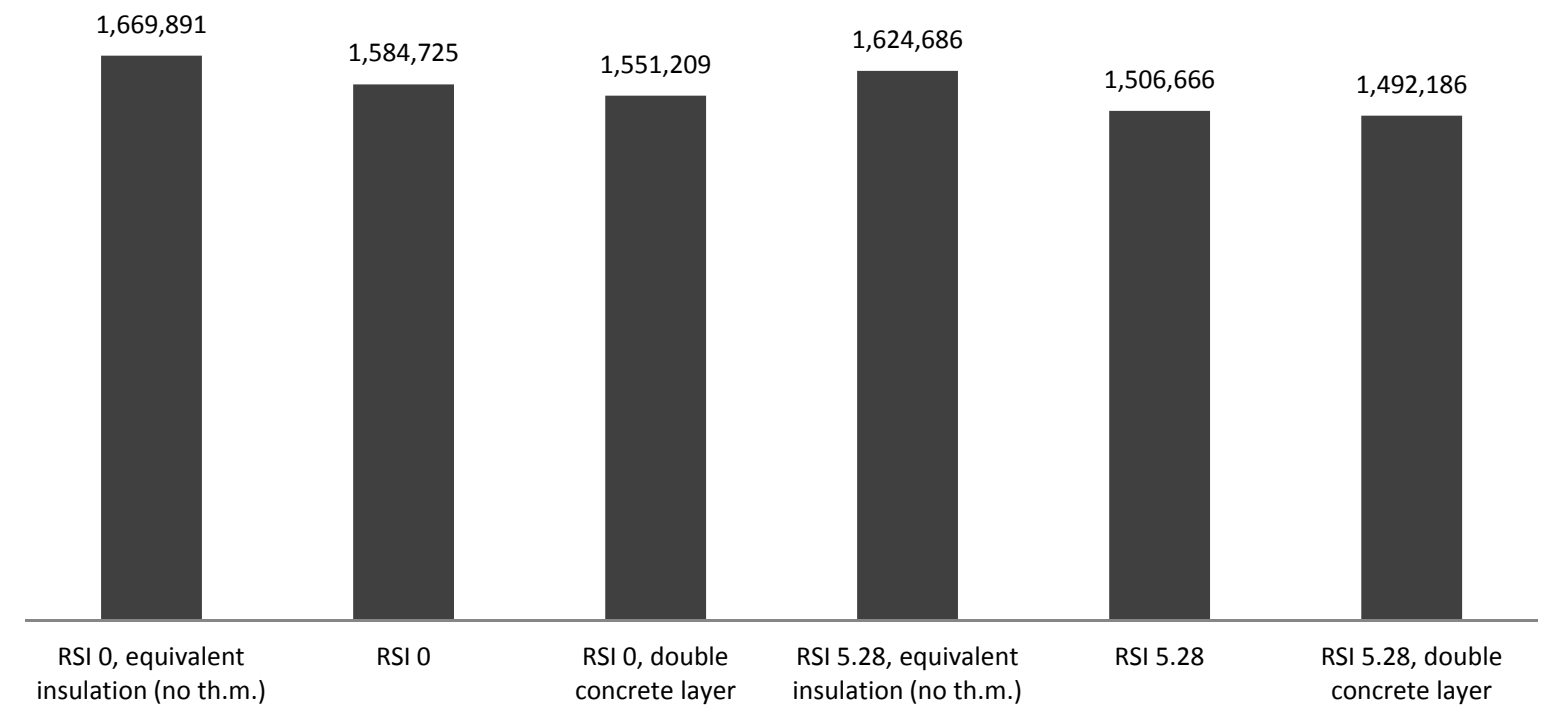

Figure 13: Annual energy required in BI system with no thermal mass/equivalent insulation level, thermal mass in greenhouse, and double thermal mass layer; two insulation levels

As opposed to the simulations with above-deck insulation, the Bl system consistently becomes more energy efficient as the level of insulation in the greenhouse footprint increases (Table 12). Specifically the heating requirement in the $\mathrm{BI}$ greenhouse decreases as the level of insulation below the concrete deck increases from no insulation to RSI $10.6 \mathrm{~m}^{2} \mathrm{~K} / \mathrm{W}$. This result indicates that there is another mechanism other than heat flux through the greenhouse footprint (which is made more difficult with high levels of insulation) by which the BI systems are improved over their SA counterparts. In the case of the BI greenhouse, it may simply be that having the thermal mass of the office building adjacent provides a beneficial effect on the conditioning energy requirement. Further research into this phenomenon is required, and may benefit from a study of urban thermal mass on greenhouses, which may also serve to answer why Lufa Farms performs so much better than a ground-level, rural counterpart (L. Rathmell, personal communication, May 6, 2013). 
However, as with the previous roof insulation variable, the simulation with no insulation in the greenhouse footprint has the lowest hours of overheating (i.e. above $30^{\circ} \mathrm{C}$ in the greenhouse), almost certainly because of the heat transfer possible through the greenhouse footprint to the office building, or the ground for the SA greenhouse. In future research with an active cooling system, this advantage may not be as important for maintenance of growing conditions in the greenhouse.

Table 12: Summary of the effect of thermal mass on energy consumption in SA vs.
\begin{tabular}{|lr|r|r|}
\hline & \multicolumn{2}{|c|}{$\begin{array}{l}\text { Total annual conditioning } \\
\text { energy (kWh) }\end{array}$} \\
\cline { 3 - 4 } & SA & BI \\
\hline No insulation & $2,021,199$ & $1,584,725$ \\
\hline Baseline insulation & $\begin{array}{r}\text { BI and SA office RSI } 5.28 \mathrm{~m}^{2} \mathrm{~K} / \mathrm{W} \\
\text { SA greenhouse RSI } 2.64 \mathrm{~m}^{2} \mathrm{~K} / \mathrm{W}\end{array}$ & $1,561,664$ & $1,506,666$ \\
\hline Super-insulated & $\mathrm{RSI} 10.6 \mathrm{~m}^{2} \mathrm{~K} / \mathrm{W}$ & $1,535,409$ & $1,504,457$ \\
\hline
\end{tabular}

Additionally, every BI simulation with thermal mass in the greenhouse (except for the first with no insulation) has a lower energy consumption for heating and cooling than the baseline SA office + SA greenhouse (Figure 14).

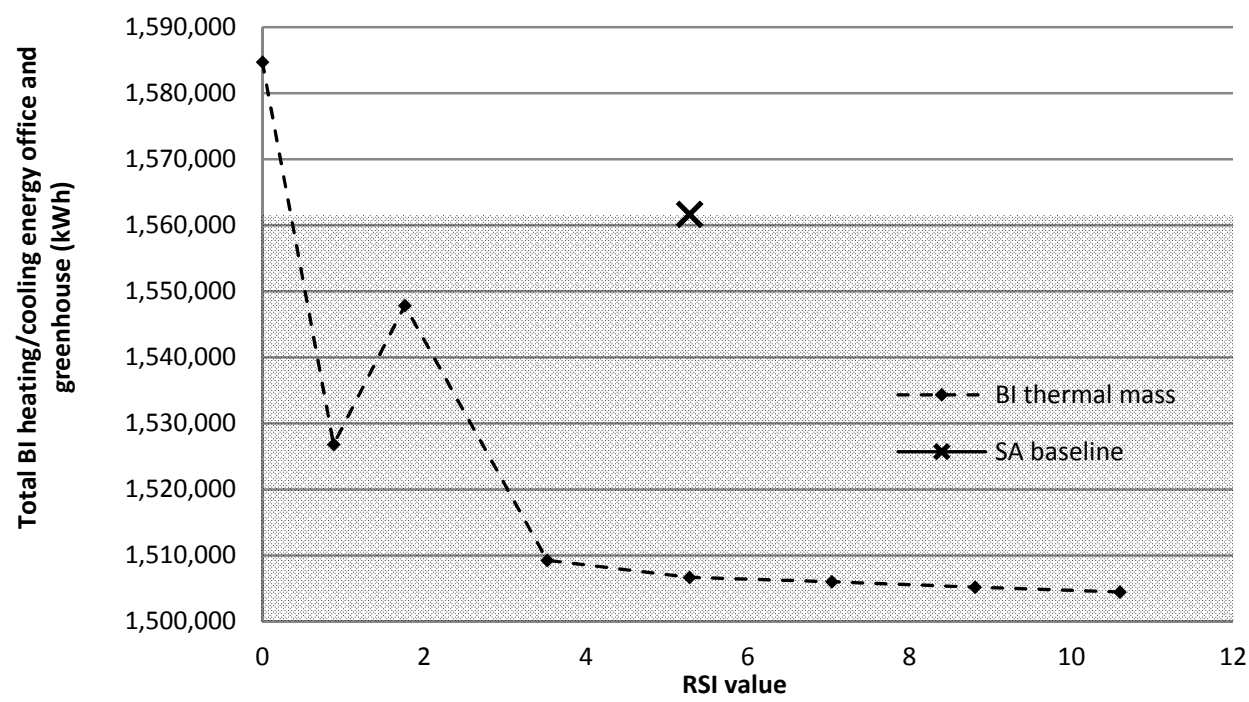

Figure 14: Comparison of BI systems with thermal mass in the greenhouse vs. the SA baseline

The BI greenhouse temperatures from the thermal mass simulations are compared with the SA greenhouse from the previous section (Effect of roof insulation, page 30) since they both benefit from thermal mass. The comparison shows that the maximum temperatures in the $\mathrm{BI}$ scenario are lower than in the SA greenhouse, while the minimum temperatures are higher, though only by less than $1^{\circ} \mathrm{C}$. This 
indicates a small benefit to integrating the greenhouse with the office building, since the $\mathrm{BI}$ systems have been shown to use less energy to achieve temperatures closer to the setpoint for the greenhouse.

In summary of the first two variables (thermal mass and roof insulation above), Figure 15 shows the impact of inverting the roof assembly in the greenhouse footprint for BI systems. The simulations with thermal mass in the greenhouse consistently perform better overall then simulations with insulation above the roof deck. Additionally, the greenhouse maximum interior temperatures are also $2-3^{\circ} \mathrm{C}$ cooler in the $\mathrm{BI}$ greenhouse with thermal mass than with the baseline roof assembly, while the minimum temperatures are $3-4^{\circ} \mathrm{C}$ warmer. This effect is greater than the max and min temperature differences between the $\mathrm{BI}$ and $\mathrm{SA}$ greenhouses described above, which were not more than $1^{\circ} \mathrm{C}$, i.e. thermal mass has a greater effect on the temperature in the greenhouse than building integration.

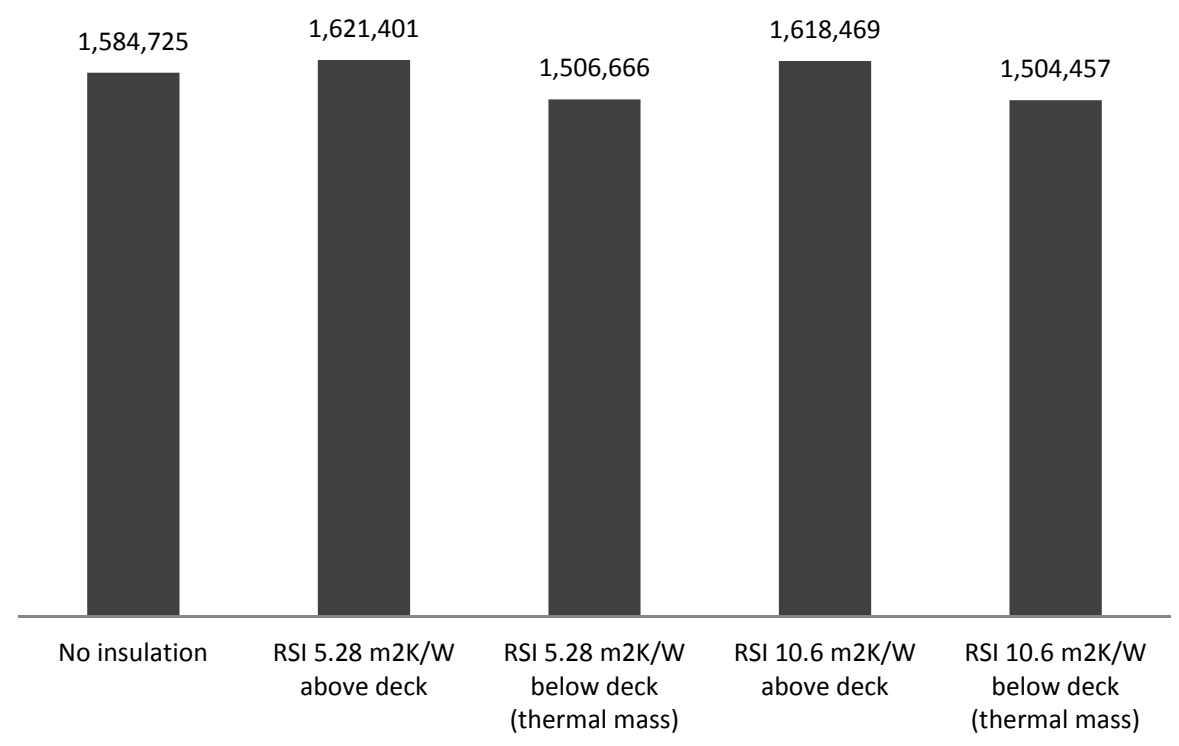

Figure 15: Comparison between baseline roof insulation simulations and thermal mass (inverted assembly) at three levels of insulation

One additional issue to consider is thermal bridging which would likely be more prominent when insulation is installed below the roof deck, since it may interfere with roof structural members. Building detailing is not automatically considered by IES-VE software, so it assumes perfect continuity in insulation whether it is above or below the roof deck; this could be achieved with careful detailing.

\subsection{Effect of greenhouse envelope}

The purpose of a greenhouse envelope is to create an interior environment conducive to plant growth, which includes, in a northern climate, both thermal resistance, and high visible transmittance in the range of photosynthetically active radiation of light (PAR), between $400-700 \mathrm{~nm}$. This corresponds 
closely to the visible spectrum, and therefore translates well to the visible transmittance property of glazing. The visible transmittance of the cover material can vary depending on the light needs of the crop grown in the greenhouse, though many agricultural crops typically grown in greenhouses (lettuce, cucumber, tomatoes) require mid to high light levels to thrive (Aldrich \& Bartok, 1994). Ideally, an agricultural greenhouse will have a visible transmittance of $89-90 \%$, although coatings exist on the market that will increase the visible transmittance to 95-96\% (G. Bonisteel, personal communication, May 30, 2013). In general, single pane horticultural glass is preferable to double pane glass, despite a large energy savings, because of the reduced light transmission both through the glass and resulting from a heavier support structure, resulting in overall reductions of plant growth and yield (Cohen \& Fuchs, 1999).

The results in Table 13 show, as expected, that as the U-value of the glazing decreases in both SA and BI greenhouses, the annual heating energy also decreases, while cooling energy increases. This indicates that glazing with better thermal resistance retains more of the heat of the HVAC system and solar radiation, reducing the energy required for heating, but increasing the level of ventilation necessary to maintain the setpoint temperatures in the cooling season, which agrees with findings in attached sunspace research (Hastings, 1981; Swann, 1996).

As shown previously in Figure 8 (in Methodology, page 25), insulation in the BI scenario is above the roof deck; in retrospect, after the thermal mass simulations, this insulation may be better placed below the roof deck, exposing the concrete layer's thermal mass to the greenhouse, which it benefits more than the office building. This presents another opportunity for further research into the overall effect of greenhouse glazing, when all other variables are maximized for energy efficiency. 
HEATING AND COOLING REQUIREMENT OF AN OFFICE BUILDING AND URBAN ROOFTOP GREENHOUSE

Table 13: Effect of greenhouse envelope, overall results

\begin{tabular}{|c|c|c|c|c|c|c|c|c|c|c|}
\hline Insulation level $\left(\mathrm{m}^{2} \mathrm{~K} / \mathrm{W}\right)$ & $\begin{array}{l}\text { Greenhouse } \\
\text { envelope }\end{array}$ & $\begin{array}{l}\text { Annual } \\
\text { space } \\
\text { heating } \\
\text { office (kWh) }\end{array}$ & $\begin{array}{l}\text { Annual } \\
\text { space } \\
\text { cooling } \\
\text { office } \\
\text { (kWh) }\end{array}$ & $\begin{array}{l}\text { Total office } \\
\text { (kWh) }\end{array}$ & $\begin{array}{l}\text { Annual space } \\
\text { heating } \\
\text { greenhouse } \\
\text { (kWh) }\end{array}$ & $\begin{array}{l}\text { Annual } \\
\text { ventilation } \\
\text { greenhouse } \\
\text { (kWh) }\end{array}$ & $\begin{array}{l}\text { Total } \\
\text { greenhouse } \\
\text { (kWh) }\end{array}$ & $\begin{array}{l}\text { Greenhouse } \\
\text { max. temp } \\
\left({ }^{\circ} \mathrm{C}\right)\end{array}$ & $\begin{array}{l}\text { Greenhouse } \\
\text { min. temp }\left({ }^{\circ} \mathrm{C}\right)\end{array}$ & $\begin{array}{l}\text { Greenhouse } \\
\text { hours above } \\
30^{\circ} \mathrm{C}\end{array}$ \\
\hline \multicolumn{11}{|c|}{ Bl system, greenhouse footprint insulation } \\
\hline RSI 5.28 & single & 685,623 & 46,045 & 731,668 & 883,634 & 5,094 & 888,728 & 38.44 & 13.05 & 635 \\
\hline RSI 5.28 & single low-e & 679,629 & 45,912 & 725,541 & 579,115 & 6,225 & 585,340 & 39.45 & 14.42 & 830 \\
\hline RSI 5.28 & double & 681,732 & 45,920 & 727,652 & 515,686 & 6,373 & 522,059 & 39.52 & 11.34 & 841 \\
\hline RSI 5.28 & $\begin{array}{l}\text { double } \\
\text { low-e }\end{array}$ & 681,577 & 45,849 & 727,426 & 433,861 & 6,821 & 440,682 & 39.74 & 8.56 & 898 \\
\hline RSI 0 & single & 683,427 & 67,212 & 750,639 & 830,798 & 3,288 & 834,086 & 35.34 & 16.91 & 306 \\
\hline RSI 0 & single low-e & 628,934 & 67,045 & 695,979 & 533,941 & 4,130 & 538,071 & 38.51 & 19.24 & 435 \\
\hline RSI 0 & double & 650,127 & 66,057 & 716,184 & 439,268 & 4,402 & 443,670 & 36.07 & 19.92 & 458 \\
\hline RSI 0 & $\begin{array}{l}\text { double } \\
\text { low-e }\end{array}$ & 647,457 & 64,154 & 711,611 & 348,685 & 4,988 & 353,673 & 36.49 & 17.77 & 537 \\
\hline \multicolumn{11}{|c|}{ SA greenhouse, underslab insulation } \\
\hline RSI 2.64 & single & - & - & - & 787,096 & 4,877 & 791,973 & 36.68 & 16.08 & 438 \\
\hline RSI 2.64 & single low-e & - & - & - & 458,600 & 6,773 & 465,373 & 37.39 & 19.3 & 636 \\
\hline RSI 2.64 & double & - & - & - & 390,554 & 7,060 & 397,614 & 37.65 & 19.86 & 668 \\
\hline RSI 2.64 & $\begin{array}{l}\text { double } \\
\text { low-e }\end{array}$ & - & - & - & 304,731 & 7,615 & 312,346 & 38.06 & 19.21 & 736 \\
\hline RSI 0 & single & - & - & - & 879,572 & 4,051 & 883,623 & 36.18 & 14.64 & 331 \\
\hline RSI 0 & single low-e & - & - & - & 573,849 & 5,560 & 579,409 & 36.85 & 19.08 & 495 \\
\hline RSI 0 & double & - & - & - & 490,937 & 5,798 & 496,735 & 37.09 & 19.06 & 530 \\
\hline RSI 0 & $\begin{array}{l}\text { double } \\
\text { low-e }\end{array}$ & - & - & - & 404,046 & 6,285 & 410,331 & 37.54 & 18.2 & 612 \\
\hline \multicolumn{11}{|l|}{ SA office, roof insulation } \\
\hline RSI 5.28 & - & 721,671 & 48,020 & 769,691 & - & - & - & - & - & - \\
\hline RSI 0 & - & $1,074,619$ & 62,957 & $1,137,576$ & - & - & - & - & - & - \\
\hline
\end{tabular}


Overall, the energy consumption of the BI system (office + greenhouse) decreases as the glazing system improves (decreasing U-value); this is consistent with the effect shown by Scott (2011) wherein an improved greenhouse envelope resulted in a lower heating requirement then single glazing. The maximum greenhouse temperatures are highest with the best envelope (double glazed, low-e), consistent with the simulation of attached sunspaces done by Mihalakakou \& Ferrante (2000). The minimum temperatures are lowest with either single glazed or double glazed low-e - this indicates that the single glazed envelope permits heat to escape the greenhouse, while the most improved envelope allows much less solar radiation to enter. However, in terms of energy consumption, the most beneficial greenhouse envelope is double glazed with a low emissivity coating on the interior surface of the exterior pane.

The results also indicate that for the BI scenario, single glazing with a low emissivity coating on the rooftop greenhouse yields the lowest energy consumption results for the office building below; lower than both double glazed, and double glazed with a low-e coating (Figure 16). The result is particularly striking when there is no insulation in the separation between the greenhouse and the office building; the model suggests a difference of more than $3 \%$ between the heating consumption of the office building with a single low-e envelope-greenhouse and the next best, double glazed, envelope.

Contrarily, the overall $\mathrm{BI}$ energy consumption is $6 \%$ less when the greenhouse is double glazed vs. single glazed, low-e.

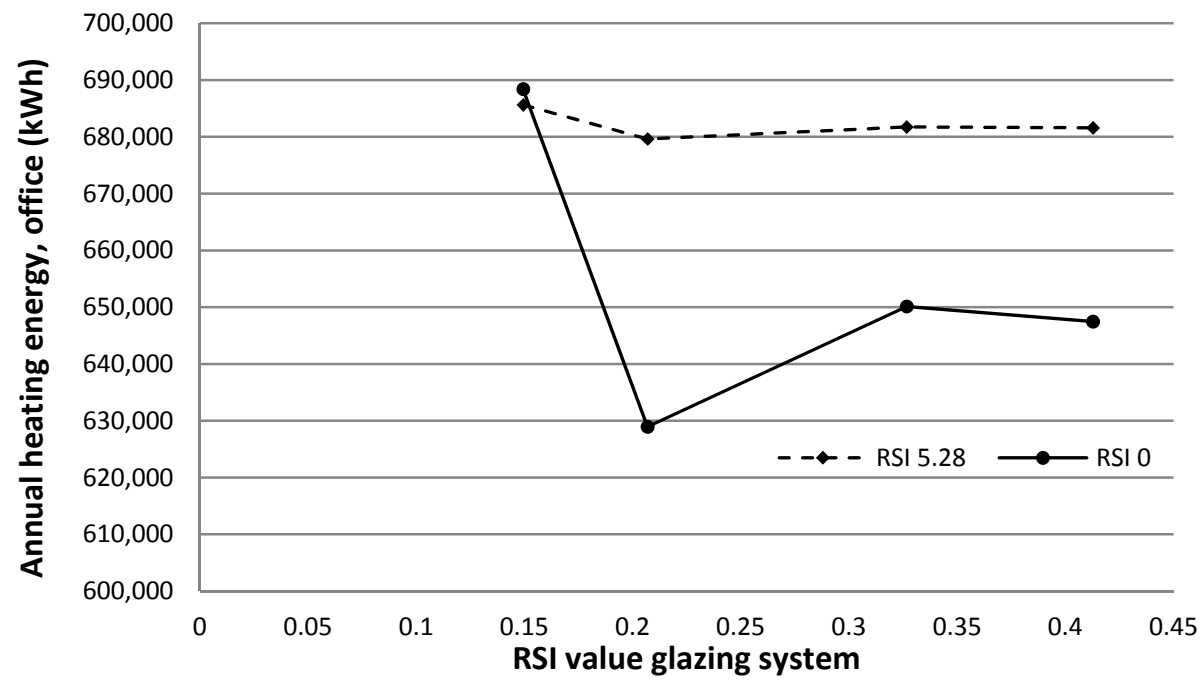

Figure 16: Office heating energy requirement, BI system with no insulation vs. RSI $5.28 \mathrm{~m}^{2} \mathrm{~K} / \mathrm{W}$ in the greenhouse footprint: single glazed, single low-e, double glazed, double low-e in order of increasing RSI value 
In further exploring the reason for the efficiency of the BI office building with this particular greenhouse envelope, it was found that the heat flux from the greenhouse to the office building is consistently greatest throughout the year when the greenhouse envelope is single glazed + low-e coating (Figure 17); it follows that the floor temperature in the greenhouse is also highest with this envelope. It appears that the greenhouse is transferring heat to the office building, which explains the lower energy consumption there, though there is no clear indication why.

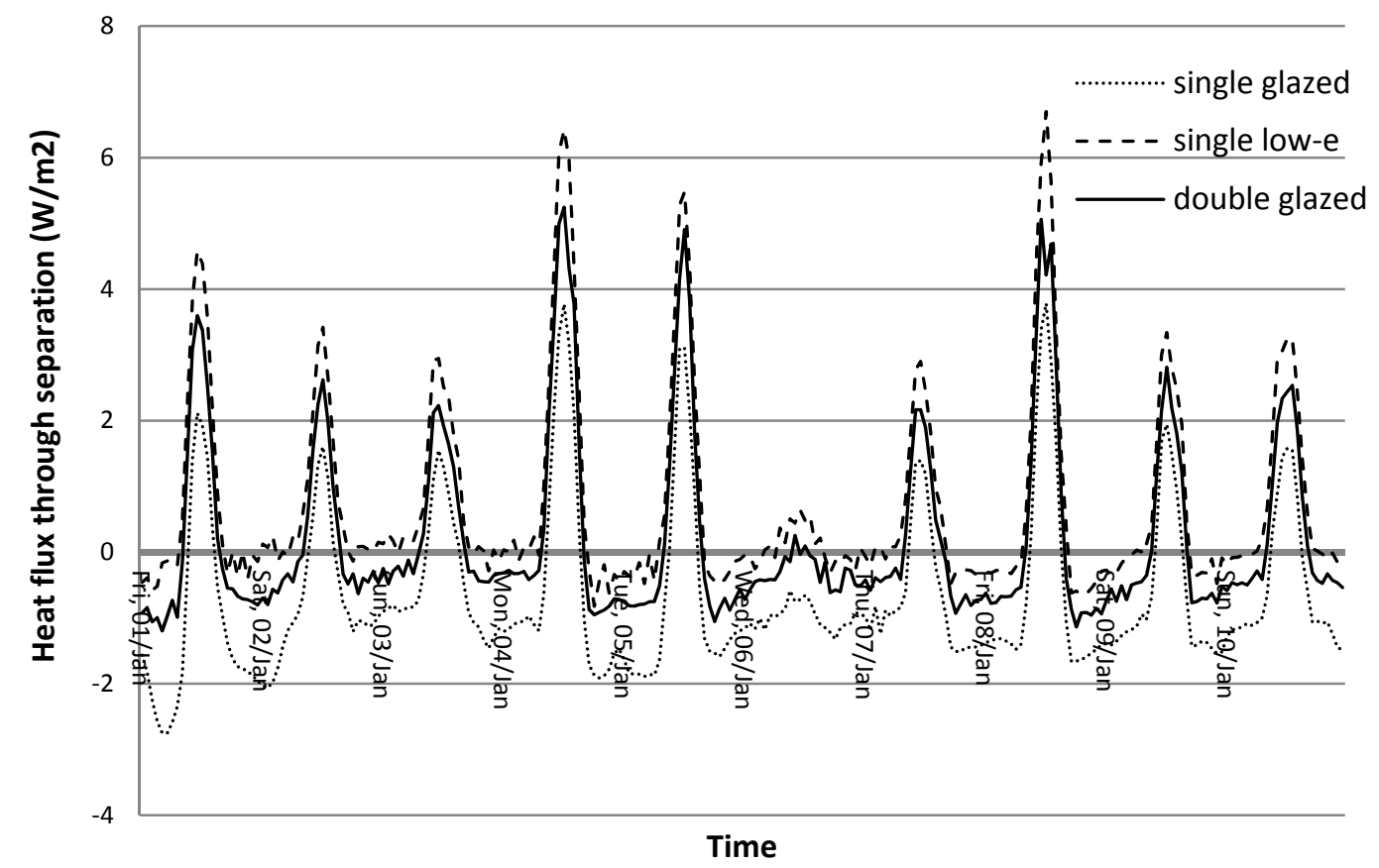

Figure 17: Heat flux through RSI $5.48 \mathrm{~m}^{2} \mathrm{~K} / \mathrm{W}$ separation with varying greenhouse envelopes; Jan. 1-10, typ. throughout year

The interior temperatures of the differently glazed greenhouses do not show any clear trends to indicate that one has a higher or lower temperature than another for any significant period during the year, except that the overheating hours in the single glazed, low-e greenhouse are higher than might be expected (not linear with the single and double glazed hours). This suggests that the heating/ventilation systems are working as expected, and are not causing this discrepancy. The temperatures in the office building below never differ by more than one degree between cases. A second set of simulations was conducted using default IES glazing constructions to ensure that there was no problem with the custom constructions input in the software from Guardian Glass/Window 6 specifications. The same trend, to the same magnitude, was observed in this set of simulations.

Therefore if the goal were to choose the BI scenario that most benefits the energy consumption of the office building, then a single pane glass with a low-emissivity coating may be the best choice for the 
greenhouse envelope. Further research should be conducted to ensure that this is the case in every scenario (i.e. when there is thermal mass in the greenhouse and insulation in the separation) and to discover the reason for this.

The BI simulations with coated and double glazed rooftop greenhouse envelopes all show lower energy consumption than the SA baseline, and the difference increases as the glazing improves (Table 14). The greenhouse maximum temperatures appear to be lower in the BI greenhouse then in the SA greenhouse for the simulations with no insulation in the greenhouse footprint. The minimum temperature was always higher in the SA greenhouse, and the maximum was less when insulation was present in the greenhouse footprint, indicating a benefit to the SA greenhouse. However, like the results from the roof insulation simulations, this SA greenhouse has a layer of concrete thermal mass exposed to the interior, while the BI greenhouse does not, so the temperatures are not exceptionally comparable. Without running additional simulations with thermal mass to the interior of the BI greenhouse while varying the greenhouse envelope, conclusions cannot be drawn based on interior temperatures.

Table 14: Summary of the effect of greenhouse envelope on energy consumption in SA vs. BI

\begin{tabular}{|c|c|c|c|c|}
\hline & Single & Single low-e & Double & Double low-e \\
\hline \multicolumn{5}{|l|}{ SA } \\
\hline RSI 5.28 office roof + RSI 2.64 greenhouse slab & $1,561,664$ & $1,235,064$ & $1,167,305$ & $1,082,037$ \\
\hline RSI 0 office roof + RSI 0 greenhouse slab & $2,021,199$ & $1,716,985$ & $1,634,311$ & $1,547,907$ \\
\hline \multicolumn{5}{|l|}{ BI } \\
\hline RSI 5.28 separation & $1,620,396$ & $1,310,881$ & $1,249,711$ & $1,168,108$ \\
\hline RSI 0 separation & $1,584,725$ & $1,234,050$ & $1,159,854$ & $1,065,284$ \\
\hline
\end{tabular}

While a thermal curtain was considered for the greenhouse, IES-VE software does not allow the screen to be installed away from the window, as it would ideally hang from the gutters of the greenhouse, 1.5 $\mathrm{m}$ below the gable of the roof. Another limitation of the software was its inability to model metallic coatings on the curtain, since the purpose of thermal night curtains is to prevent thermal radiation loss from the greenhouse which is most efficiently done with an aluminized curtain (Gupta \& Chandra, 2002). One simulation was run using a thin but opaque aluminum layer, arranged horizontally at the gutters separating the gables of the greenhouse from the lower rectangular prism. The simulation did not provide any conclusive results as the aluminum partition could not be retracted during the day.

Therefore, in terms of overall energy consumption, the most beneficial greenhouse glazing type is double glazed with a low emissivity coating. However it is recommended that greenhouse glazing have a 
visible transmittance of at least $89 \%$, so the low visible transmittance of a double glazed, low-e envelope will likely hinder crop growth. Additionally, the issue of condensation should be explored in future research as the simulation software gave preliminary indications of condensation on the greenhouse envelope, which can significantly reduce light transmission to plants in the greenhouse. Exploring other possible envelope systems including the numerous plastics available would be a logical next step, investigating combinations of high thermal resistance, and high transmittance. Plastic envelopes are additionally beneficial because of their light-weight, although they are less durable than glass.

\subsection{Effect of evapotranspiration \& high pressure sodium light models} Evapotranspiration and supplementary lighting models are introduced into the model to show what effect the interior loading of a functioning rooftop greenhouse might have on the BI system.

In all three scenarios (moderate load, latent load, latent load + lights), the baseline SA office + SA greenhouse with better-than-average insulation levels in the roof and slab respectively, shows a lower overall heating and cooling energy consumption than any BI scenario, suggesting initially that a rooftop greenhouse does not provide an overall benefit to this BI configuration (Table 15). Note, however, that the SA greenhouse has the benefit of thermal mass, to which the BI greenhouse does not have access since the $\mathrm{BI}$ office roof insulation is entirely above deck (see Figure 8 in Methodology, page 25). With no insulation in the greenhouse footprint (i.e. maximum thermal interaction), the BI system shows lower maximum and higher minimum greenhouse temperatures then the SA greenhouse, indicating a benefit to the interaction. 
HEATING AND COOLING REQUIREMENT OF AN OFFICE BUILDING AND URBAN ROOFTOP GREENHOUSE

Table 15: Effect of greenhouse interior loading, overall results

\begin{tabular}{|c|c|c|c|c|c|c|c|c|c|c|c|}
\hline $\begin{array}{l}\text { Insulation } \\
\text { level in } \\
\text { greenhouse } \\
\text { footprint } \\
\mathrm{m}^{2} \mathrm{~K} / \mathrm{W} \\
\end{array}$ & $\begin{array}{l}\text { Greenhouse } \\
\text { treatment }\end{array}$ & $\begin{array}{l}\text { Annual } \\
\text { space } \\
\text { heating } \\
\text { office (kWh) }\end{array}$ & $\begin{array}{l}\text { Annual } \\
\text { space } \\
\text { cooling } \\
\text { office (kWh) }\end{array}$ & $\begin{array}{l}\text { Total } \\
\text { office } \\
\text { (kWh) }\end{array}$ & $\begin{array}{l}\text { Annual space } \\
\text { heating } \\
\text { greenhouse } \\
\text { (kWh) }\end{array}$ & $\begin{array}{l}\text { Greenhouse } \\
\text { HPS light } \\
\text { heating energy } \\
\text { (kWh) }\end{array}$ & $\begin{array}{l}\text { Annual } \\
\text { ventilation } \\
\text { greenhouse } \\
\text { (kWh) } \\
\end{array}$ & $\begin{array}{l}\text { Total } \\
\text { greenhouse } \\
\text { (kWh) }\end{array}$ & $\begin{array}{l}\text { Greenhouse } \\
\max \text { temp } \\
\left({ }^{\circ} \mathrm{C}\right)\end{array}$ & $\begin{array}{l}\text { Greenhouse } \\
\text { min. temp } \\
\left({ }^{\circ} \mathrm{C}\right)\end{array}$ & $\begin{array}{l}\text { Greenhouse } \\
\text { hours above } \\
30^{\circ} \mathrm{C}\end{array}$ \\
\hline \multicolumn{12}{|c|}{ Bl system, greenhouse footprint insulation } \\
\hline RSI 5.28 & $\begin{array}{l}\text { moderate } \\
\text { load }\end{array}$ & 684,635 & 45,816 & 730,451 & 885,886 & 0 & 5,064 & 890,950 & 38.47 & 13.05 & 635 \\
\hline RSI 5.28 & latent load & 684,796 & 46,051 & 730,847 & 947,559 & 0 & 4,409 & 951,968 & 38.51 & 9.97 & 648 \\
\hline RSI 5.28 & $\begin{array}{l}\text { latent + } \\
\text { lights }\end{array}$ & 685,191 & 46,073 & 731,264 & 892,682 & 73,771 & 4,415 & 970,868 & 38.51 & 11.4 & 648 \\
\hline RSI 0 & $\begin{array}{l}\text { moderate } \\
\text { load }\end{array}$ & 683,427 & 67,212 & 750,639 & 830,798 & 0 & 3,288 & 834,086 & 35.34 & 16.86 & 306 \\
\hline RSI 0 & latent load & 670,793 & 68,050 & 738,843 & 920,561 & 0 & 2,640 & 923,201 & 35.36 & 13.6 & 314 \\
\hline RSI 0 & $\begin{array}{l}\text { latent + } \\
\text { lights }\end{array}$ & 667,943 & 68,140 & 736,083 & 862,205 & 73,771 & 2,637 & 938,613 & 35.36 & 14.91 & 313 \\
\hline \multicolumn{12}{|c|}{ SA greenhouse, underslab insulation } \\
\hline RSI 2.64 & $\begin{array}{l}\text { moderate } \\
\text { load }\end{array}$ & - & - & - & 787,096 & 0 & 4,877 & 791,973 & 36.69 & 16.08 & 438 \\
\hline RSI 2.64 & latent load & - & - & - & 862,585 & 0 & 4,815 & 867,400 & 36.72 & 13.13 & 443 \\
\hline RSI 2.64 & $\begin{array}{l}\text { latent + } \\
\text { lights }\end{array}$ & - & - & - & 803,954 & 73,771 & 4,818 & 882,543 & 36.72 & 14.48 & 444 \\
\hline RSI 0 & $\begin{array}{l}\text { moderate } \\
\text { load }\end{array}$ & - & - & - & 879,572 & 0 & 4,051 & 883,623 & 36.19 & 14.64 & 331 \\
\hline RSI 0 & latent load & - & - & - & 962,045 & 0 & 3,904 & 965,949 & 36.21 & 11.65 & 344 \\
\hline RSI 0 & $\begin{array}{l}\text { latent + } \\
\text { lights }\end{array}$ & - & - & - & 907,487 & 73,771 & 3,909 & 985,167 & 36.21 & 12.93 & 344 \\
\hline \multicolumn{12}{|c|}{ SA office, roof insulation } \\
\hline RSI 5.28 & - & 721,671 & 48,020 & 769,691 & - & - & - & - & - & - & - \\
\hline RSI 0 & - & $1,074,619$ & 62,957 & $1,137,576$ & - & - & - & - & - & - & - \\
\hline
\end{tabular}




\subsubsection{Evapotranspiration load}

When introducing a latent load in the BI greenhouse, the energy required for ventilation for cooling dropped slightly - while the heating energy increases by almost $10 \%$ - and the hours of overheating are halved. Figure 18 shows that the increase in heating energy required is most prominent during the heating season; this may be because the process of transpiration (and the latent load in the simulation software) requires energy to convert liquid water in the crops to vapour in the air, which in turns demands more energy from the heating system. This corresponds with an evaporative cooling effect, as predicted by studies of green roofs (Jaffal et al., 2012). While the greenhouse did require less cooling when the latent load was added, it also required much more heating, suggesting perhaps that the cooling effect achieved with a latent load is not beneficial overall in a heating dominated climate. The changes in energy requirement for heating and cooling when the latent load is introduced are consistent with results found in the study of an attached sunspace planted with grass (Mihalakakou \& Ferrante 2000), though the maximum and minimum temperatures in the greenhouse do not necessarily reflect a "cooling effect". The minimum temperatures are lower when a latent load is introduced as expected, while the maximum temperatures remain essentially constant, not demonstrating a cooling effect.

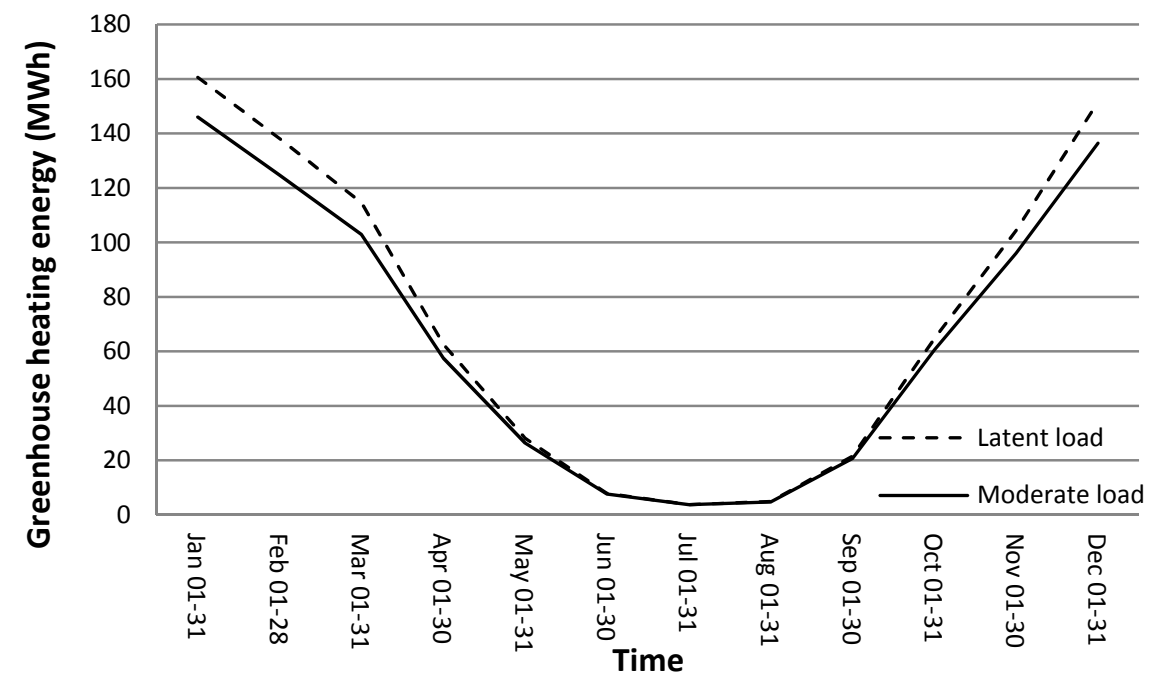

Figure 18: Annual SA greenhouse heating energy, with and without latent load of ET

Because of the low outdoor temperatures in the heating season, the ventilation system is typically not running; the fans are set to come on when the greenhouse interior temperature reaches $26^{\circ} \mathrm{C}$. This lack of ventilation in the presence of a latent load maintains the relative humidity near $100 \%$ during the heating season, which is only slightly improved by ventilation during the cooling season (Figure 19). Even a reduction of the maximum latent load in the greenhouse by $50 \%$ (to a maximum of $100 \mathrm{~W} / \mathrm{m}^{2}$, instead 
of $205 \mathrm{~W} / \mathrm{m}^{2}$ ) did not greatly reduce the instance of $100 \% \mathrm{RH}$. Attempts to counteract the effect with exceptionally high ventilation lead to a better climate in the summer, but low temperatures in the winter.

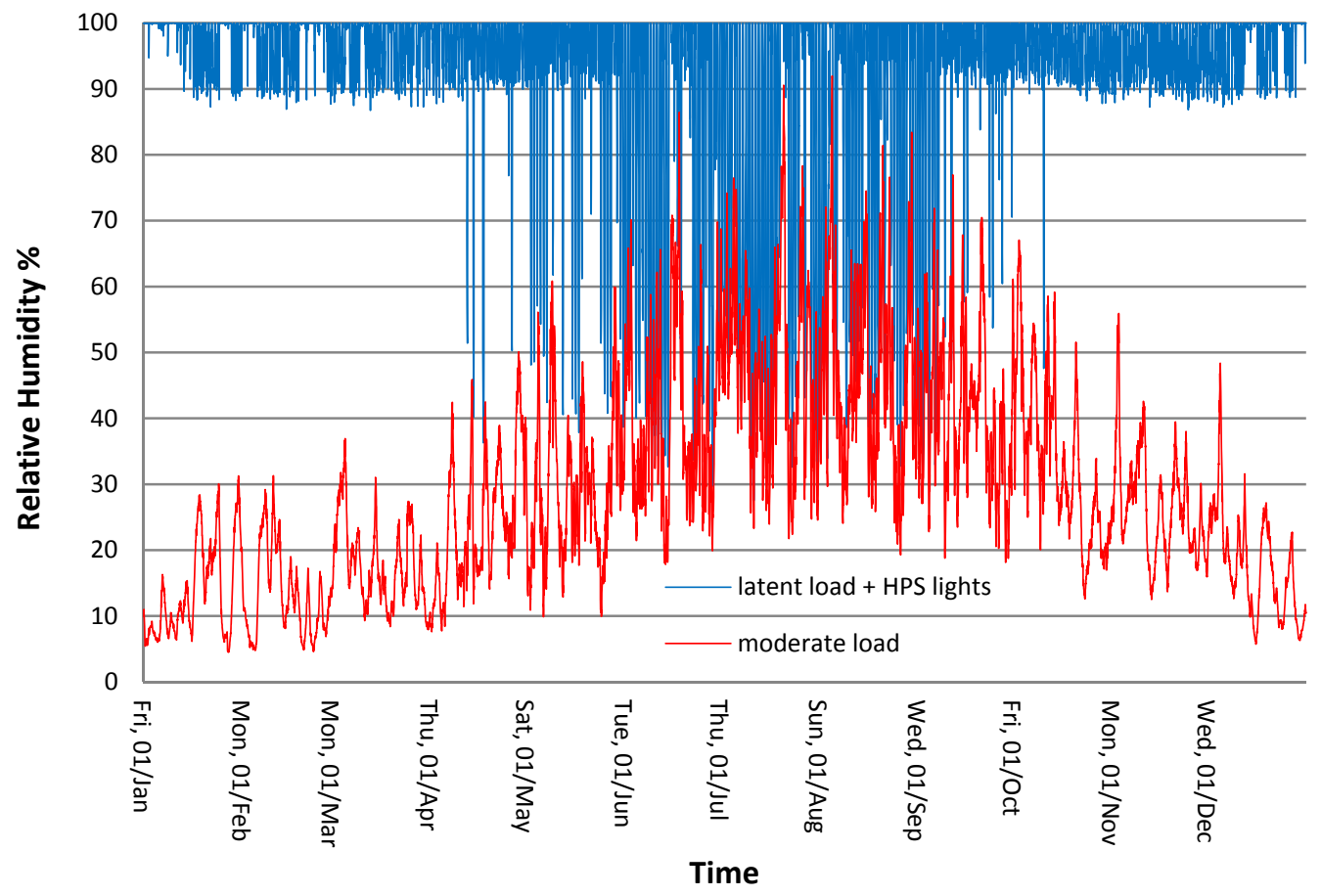

Figure 19: SA greenhouse relative humidity, with and without latent load of ET

A significant limitation of this ET model is that the crops in the greenhouse are modelled as being constantly 'on' according to the schedule, and don't respond actively to conditions in the greenhouse. In reality, the high levels of humidity achieved in the greenhouse with the latent load would effectively halt plant transpiration (Stanghellini, 1987). The model created assumed levels of transpiration based on incoming solar radiation, assuming that the temperature and relative humidity in the greenhouse was maintained near the proper setpoints.

The maintenance of a high relative humidity $(60-80 \%)$ without exceeding $80 \%$ for extended periods is required for optimum crop growth. Therefore in future research involving the energy modelling of greenhouses, a balance must be found between the plant latent load and a method of dehumidification, which could amount simply to finer controllability of the ventilation system, or a more reactive model of plant ET. Further research involving heat recovery from the exhaust air of the greenhouse or the office building is important to reduce the energy involved in ventilating then reheating the greenhouse in the heating season. 


\subsubsection{Supplementary lighting load}

When HPS lights are introduced in the greenhouse the HVAC system heating requirement decreases because of the waste heat provided by these lights which have only approximately $30 \%$ efficiency for lighting. Table 15 shows $70 \%$ of the total lighting power as contributing directly to heating the greenhouse. Therefore, the HPS lights provide between 8 and $10 \%$ of the total heating energy in the initial simulations; less than what was predicted anecdotally (15-41\%), which could indicate a high base greenhouse heating load. Because a proportion of the energy from the HPS lights is converted directly to heat, this fraction (70\%) of their energy is added to the heating energy requirement. Therefore, the total energy required to heat the greenhouse with HPS lights is higher than without, because of the inferior efficiency of the lights for heating (as compared with $90 \%$ efficient condensing boiler). This problem may soon be resolved for greenhouse operations requiring supplementary lighting with the adoption of LED grow lights, poised to begin soon, which require far less energy total, and are much more efficient for lighting and do not contribute significant heat (Gomez et al., 2013).

The greenhouse maximum temperatures tend to increase when a latent load is added, though the difference is very small. The simulations run with the latent load of ET during the heating season show lower minimum temperatures (up to $3-4^{\circ} \mathrm{C}$ lower) at night than the greenhouse with moderate loads (Figure 20). In both systems, the lowest dips are experienced after particularly sunny days (i.e. February 2 , and 3 ). The differences likely have to do with the controllability of the heating system in the greenhouse, as it is more difficult for the HVAC system to adjust to the loss of heat from solar radiation when it was sunny and more difficult again when the additional latent load is demanding energy from the heating system. As mentioned before, however, the total overheating hours in the greenhouse (above $30^{\circ} \mathrm{C}$ ) are significantly reduced, confirming the cooling effect of the latent load. When the HPS lights are introduced, the minimum is reduced, most likely because the HPS lights stay on later/turn on earlier than the sun sets or rises. However in simulations both with insulation and without, maximum greenhouse temperatures are shown to be lower in the BI greenhouse than the SA greenhouse, and the minimums higher. Both of these results suggest that the office building has a moderating effect on the greenhouse, and demonstrate a positive benefit of integrating the greenhouse with the office building. Future research may focus on ways of controlling the heating system more tightly to prevent excessively low temperatures in the greenhouse. 


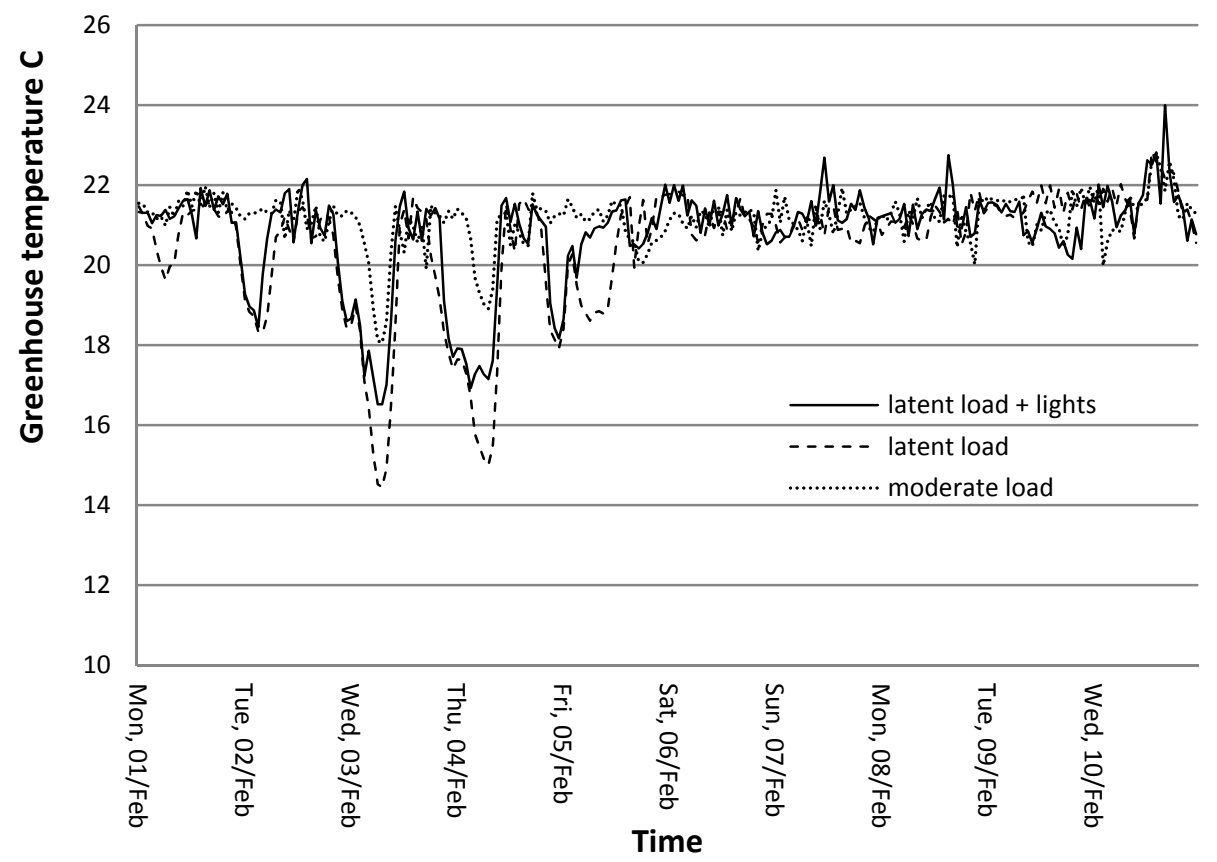

Figure 20: Effect of latent load and HPS lights on greenhouse interior temperature; Feb. 1-10, typ. throughout year

Although the cooling load is reduced in the presence of a latent load in all simulations, the temperatures in the summer still reach between $30-38^{\circ} \mathrm{C}$ daily. While some crops can survive this heat, others are more delicate and require a more constant low temperature. Lufa Farms aims for a cooling season setpoint of $26^{\circ} \mathrm{C}$, although outdoor temperatures in the summer are acceptable for most crops, and are maintained using mechanical and natural ventilation (L. Rathmell, personal communication, May 6, 2013). This still results in a lower temperature in reality than was demonstrated in this simulation model, which is an important avenue for further research: specifically, the controllability of the cooling system. Future research should investigate methods for preventing overheating in the summer. The use of an evaporative cooling pad, for example, would change the cooling energy consumption in the greenhouse entirely.

These observations, compiled in Table 16, highlight the fact that the latent and sensible loads of greenhouse plants and supplementary lighting are important factors in the annual heating and cooling load. This is also an important avenue for further research, in which detailed evapotranspiration and supplementary lighting models should be developed, and used to test energy consumption and controllability of greenhouse environments. 


Table 16: Summary of the effect of greenhouse interior loading on energy consumption in SA vs. BI
\begin{tabular}{|l|r|r|r|}
\hline \multicolumn{1}{|l|}{$\begin{array}{l}\text { Moderate } \\
\text { loads }\end{array}$} & $\begin{array}{l}\text { Latent load } \\
\text { HPS lights }\end{array}$ \\
\hline SA & 1561664 & 1637091 & 1652234 \\
\hline RSI 5.28 office roof + RSI 2.64 greenhouse slab & 2021199 & 2103525 & 2122743 \\
\hline RSI 0 office roof + RSI 0 greenhouse slab & & & \\
\hline BI & 1621401 & 1682815 & 1702132 \\
\hline RSI 5.28 separation & 1584725 & 1662044 & 1674696 \\
\hline RSI 0 separation
\end{tabular}

Overall, therefore, adding a latent load or a latent load + supplementary lighting has been demonstrated to have a higher overall energy requirement for conditioning. The supplementary lighting showed as predicted a reduction in HVAC heating energy, replaced in part by HPS lights which are a much less efficient method of heating, increasing the total energy consumption. The rudimentary models require further study to make any conclusive statements about the effect of transpiration and supplementary lighting specifically.

Further research into a more complex HVAC system is an important next step for research regarding rooftop greenhouses, which should improve controllability of the greenhouse environment with evapotranspiration and lighting loads, keeping it within ideal ranges at all times, and may provide additional benefits for the heating/cooling energy of the office building and greenhouse.

\subsection{Best case (BI) scenario}

In adding a latent load, and then supplementary lighting load, the energy consumption for heating and cooling of the full system increased, but the model showed only a difference of 6-7\% overall, suggesting the change would be small. This is also because the effect is confined mostly to the greenhouse, which is only part of the system.

When changing the level of above deck insulation between the greenhouse and office building, a maximum of $2 \%$ difference was found in the model (when discounting the instable simulations) suggesting that the change is essentially insignificant given the margin of error in the accuracy of the model itself.

The building integrated simulations including a latent load + supplementary lighting and roof insulation above deck (i.e. no thermal mass in the greenhouse) consistently performed worse than the baseline standalone greenhouse + office building. 
In the $\mathrm{BI}$ thermal mass simulations, increasing the level of insulation from nothing to RSI $10.6 \mathrm{~m}^{2} \mathrm{~K} / \mathrm{W}$ yielded a small amount of energy savings, which the model indicates is less than $4 \%$. The difference, however, between the simulations with thermal mass in the greenhouse (insulation below deck) vs. insulation above deck showed twice that difference - a more substantial $7 \%$ in the model. The BI simulations also showed a consistent improvement over the SA systems.

Increasing the resistance of greenhouse glazing showed great improvement to the heating and cooling requirement of the $\mathrm{BI}$ systems; the model suggests that double glazed low-e glass could reduce the energy requirement of the combined office building and rooftop greenhouse by as much as $30 \%$ over the baseline single glazing. However, there was a negligible difference between the $\mathrm{BI}$ and combined SA scenarios when glazing was improved, although the model indicated in every simulation that the $\mathrm{BI}$ system had performed better. The greenhouse glazing variable showed the largest improvement in the model, and is therefore the most important change to consider in a greenhouse to save energy on conditioning.

From these results, it appears from the simulation results that the best performing rooftop greenhouses (i.e. with the lowest annual energy requirement for heating and cooling in the office building and greenhouse) will have the highest resistance greenhouse envelope possible and incorporate thermal mass in the greenhouse. With thermal mass present, the performance continues to improve as the level of insulation below the concrete roof deck is increased from nothing to RSI $10.6 \mathrm{~m}^{2} \mathrm{~K} / \mathrm{W}$. The performance improves again when the level of thermal mass is increased. These variables in concert will almost certainly show an improvement over the equivalent summed SA greenhouse and office building. Though it requires additional investigation, further improvement might be achieved by developing a separation with thermal mass facing both the office and the greenhouse, with insulation as an interior layer.

The only difference to these directives would come if the goal was to improve energy consumption specifically for the office building; in that case it would be most beneficial to clad the greenhouse in single low-e glazing, resulting in a lower energy requirement in the office building although the overall energy use for heating and cooling would be slightly higher than an equivalent situation with improved glazing. This result is discussed above (see Effect of greenhouse envelope, page 40), and is an important avenue for further study. 


\section{Conclusions}

This research investigates the impact of building integration on the annual heating and cooling energy requirement of an urban rooftop greenhouse and a typical six-storey office building. With the correct parameters, the results indicate positive trends suggesting additional value, beyond local produce, in providing rooftop greenhouses on urban office buildings.

The simulations adjusting insulation in the greenhouse footprint first increased the conditioning energy requirement (up to RSI $1.76 \mathrm{~m}^{2} \mathrm{~K} / \mathrm{W}$ ), then began to decrease as the insulation approached superinsulated. The simulation with the lowest total energy requirement for space conditioning in the office and greenhouse was the one with no insulation separating the structures, most likely because of the thermal mass exposed to the greenhouse when no insulation was included above the offices' roof deck. In all cases, the building integrated simulations performed more poorly than the stand-alone baseline (the sum of the SA office with RSI $5.28 \mathrm{~m}^{2} \mathrm{~K} / \mathrm{W}$ in the roof, and the SA greenhouse with RSI $2.64 \mathrm{~m}^{2} \mathrm{~K} / \mathrm{W}$ underslab insulation).

The addition of thermal mass to the greenhouse, by inverting the roof assembly in the greenhouse footprint, showed an improvement over previous simulations when insulation instead of concrete was exposed to the inside of the greenhouse. With thermal mass in the greenhouse, increasing the level of insulation below the roof deck improved energy consumption in the rooftop greenhouse. Also, all building-integrated simulations showed an improvement over the stand-alone baseline, indicating that thermal mass is an important element in equating rooftop greenhouses with their stand-alone counterparts.

In changing the greenhouse envelope, a considerable energy savings was found when the glazing was improved from single pane with no coating, to double pane with a low emissivity coating. The office portion of the building-integrated system was found to perform best when the rooftop greenhouse was clad in single glazing with a low-e coating, although these simulations still had a higher overall (office + greenhouse) heating and cool energy consumption than improved envelopes. Additionally, all buildingintegrated simulations, except the baseline single glazing, were found to perform better than the standalone baselines corresponding to the various greenhouse envelopes.

The simulations wherein a latent load, representing plant transpiration, was added to the greenhouse result in an increased overall energy requirement in the rooftop greenhouse, likely due to the energy required to convert the latent load to vapour. While the cooling requirement decreases when the latent 
load is added, the energy required for heating increases much more, suggesting that in a heating dominated climate, a greenhouse latent load will never be exclusively beneficial. Next, the addition of supplementary lighting in the greenhouse increases energy consumption again, demonstrating the effect of using a much less efficient heat source (high-pressure sodium lights) to supplement greenhouse heating.

Therefore, the greatest energy savings for an integrated office building and rooftop greenhouse would be achieved with the highest resistance envelope possible (which may be limited by the needs of plants grown in the greenhouse), incorporation of thermal mass in the greenhouse, and a high level of insulation below the roof deck, in the greenhouse footprint.

\subsection{Limitations}

The results of this research show trends indicating which variables may be most important in reducing the heating and cooling energy consumption of a rooftop greenhouse and office building. Because the model was not calibrated with an existing building, the results are not indicative of absolute savings, and require further research to quantify.

Additionally, to conclusively pinpoint the effect of evapotranspiration and HPS lights on the energy consumption of the system, more detailed models of greenhouse latent and sensible loads must be generated, and calibrated, for use in the simulation model.

Finally, the thermal mass variable in future studies may be shown to have a different effect on the greenhouse when furniture and obstructions and/or plant transpiration is incorporated in the greenhouse.

\subsection{Future work}

Areas of this research that require further study, and similar topics are included below:

- Repetition of this research with either a calibrated simulation, or a built rooftop greenhouse.

- A specific study of the impact of plants in a rooftop greenhouse on system energy loads. The model included herein was rudimentary, and did not reflect the dynamic nature of plant transpiration.

- Alternative greenhouse envelope improvements, including the use of plastics, which can have better visible transmittance and better thermal resistance than glass. Glass is especially heavy and may not always be suitable for rooftop greenhouses. Thermal night curtains should also improve the heating 
requirement in the greenhouse, by reducing radiation to the night sky, though they were not modelled herein due to limitations of the simulation software.

- Changing the characteristics of the separation between the greenhouse and the office building. The effect of adding additional thermal mass, and its placement in the greenhouse could be important for further energy savings. A separation with thermal mass to the top and bottom (with insulation as an interior layer) might be investigated.

- Further simulations removing the effects of thermal mass from the building-integrated scenario (i.e. replacing concrete in the separation with an equivalent level of insulation) would provide additional information to explain the impact of a rooftop greenhouse on the heating and cooling requirement of the system.

- Development of an HVAC system able to actively move heat from the greenhouse to the office building and vice versa, in order to optimize the indoor environment of both spaces and reduce the energy requirement for conditioning. The small passive benefits demonstrated in this research could be massively improved with a system designed to take advantage of the best in both environments. Additionally, various other symbioses are possible to recycle other forms of waste/exhaust from the host building, including $\mathrm{CO}_{2}$ cycling (both from combustion heating systems, and from air-tight interior occupied areas) and waste water recycling. There may also be savings possible by combining the boiler loops of the office building with the greenhouse instead of running two separate HVAC systems.

- Testing how existing office buildings react to the addition of a rooftop greenhouse. In this research, the HVAC system was sized before every simulation; when the office building has a fixed HVAC system, how does a rooftop greenhouse impact the heating/cooling requirement, and the interior environment? This could also create a discussion involving the costs associated with adding a rooftop greenhouse, and whether they could be offset with energy savings; if not, perhaps offset by the productive potential of the greenhouse.

- Specific comparison of the energy required to produce and transport food into the city, with the energy it takes to produce food in an urban rooftop greenhouse, and/or other methods of urban agriculture.

- The effect of elevation on the rooftop greenhouse; whether a greenhouse could be effectively installed on the roof of a two or ten storey building.

- Discussion of the potential reduction of urban heat island effect due to rooftop greenhouses. Conversely, the impact that UHI effect has on the performance of urban rooftop greenhouses. 
By providing answers to four research questions - regarding evapotranspiration and supplementary lighting, roof insulation levels, greenhouse envelope composition, and thermal mass - this investigation offers a starting point for future research concerning the operational performance of rooftop greenhouses, and provides an additional argument for their implementation. 


\section{References}

Agriculture and Agri-Food Canada. (1987). In Rudnitski S. M. (Ed.), Energy-conserving Urban Greenhouses for Canada: Construction and Management. Ottawa: Government of Canada. Retrieved from http://publications.gc.ca/pub?id=433116\&sl=0

Aldrich, R. A., \& Bartok, J. W. (1994). Greenhouse Engineering. Ithaca: Natural Resource, Agriculture and Engineering Service.

American Society of Heating, Refrigerating and Air-Conditioning Engineers. (2010). ASHRAE 90.1-2010 (IP edition). Atlanta: ASHRAE.

American Society of Heating, Refrigerating and Air-Conditioning Engineers. (2011). Advanced Energy Design Guide for Small to Medium Office Buildings. Atlanta: ASHRAE.

Argus Controls. (2010). Light and Lighting Control in Greenhouses. (). White Rock, BC: Argus Control Systems Ltd. Retrieved from http://www.arguscontrols.com/resources/Light-and-Lighting-Controlin-Greenhouses.pdf

Astee, L. Y., \& Kishnani, N. T. (2010). Building integrated agriculture: Utilising rooftops for sustainable food crop cultivation in Singapore. Journal of Green Building, 5(2), 105-113.

BOMA Canada. (2011). BOMA BESt Energy and Environmental Report. Toronto: BOMA Canada. Retrieved from http://www.bomacanada.ca/BBEER_Report_2011/BBEER\%202011\%20FINAL.pdf

Boulard, T., \& Wang, S. (2000). Greenhouse crop transpiration simulation from external climate conditions. Agricultural and Forest Meteorology, 100(1), 25. doi:10.1016/S0168-1923(99)00082-9"

Boulianne, A. (2011). Tomatoes under lights. Greenhouse Canada, March Retrieved from http://www.greenhousecanada.com/index.php?option=com_content\&task=view\&id=2689\&Itemid $=9999$

Calpas, J. (2003). Management of the Greenhouse Environment. Government of Alberta. Retrieved from http://www1.agric.gov.ab.ca/\$department/deptdocs.nsf/all/opp2902

Canadian Mortgage and Housing Corporation. (2000). Slab-on-grade construction. (Research Highlights No. Technical Series 2000-127). Ottawa: CMHC. Retrieved from http://www.cmhcschl.gc.ca/publications/en/rh-pr/tech/2000-127E.html

Caplow, T., \& Nelkin, J. (2007). Building-integrated greenhouse systems for low energy cooling. 2nd PALENC Conference and 28th AIVC Conference on Building Low Energy Cooling and Advanced Ventilation Technologies in the 21st Century Crete island, Greece. 172-176.

Cohen, S., \& Fuchs, M. (1999). Measuring and predicting radiometric properties of reflective shade nets and thermal screens. Journal of Agricultural Engineering Research, 73(3), 245-255. 
Delor, M. (2011). Current state of Building-Integrated Agriculture, its energy benefits and comparison with green roofs - Summary. Sheffield: University of Sheffield.

Gomez, C., Morrow, R. C., Bourget, C. M., Massa, G. D., \& Mitchell, C. A. (2013). Comparison of intracanopy light-emitting diode towers and overhead high-pressure sodium lamps for supplemental lighting of greenhouse-grown tomatoes. HortTechnology, 23(1), 93-98.

Gotham Greens. (2013). Gotham Greens. Retrieved February 15, 2013, from http://gothamgreens.com/

Goulding, J. R., Owen, L. J., \& Steemers, T. J. (1992). Energy in Arcitecture: The European Passive Solar Handbook Batsford.

Gupta, M. J., \& Chandra, P. (2002). Effect of greenhouse design parameters on conservation of energy for greenhouse environmental control. Energy, 27(8),777-794.doi:10.1016/S0360-5442(02)00030-0

Hadley, P. (2011). New developments in greenhouse structures. Proceedings of the UK Controlled Environment Users' Group, 22 16-20.

Hastings, S. R. (1981). Analysis of an attached greenhouse in a low isolation northern climate. Proceedings of the American Section of the International Solar Energy Society, Portland, Oregon , 6 251-255.

Jaffal, I., Ouldboukhitine, S., \& Belarbi, R. (2012). A comprehensive study of the impact of green roofs on building energy performance. Renewable Energy, 43(0), 157. doi:10.1016/j.renene.2011.12.004"

Jo, J. H., Carlson, J. D., Golden, J. S., \& Bryan, H. (2010). An integrated empirical and modelling methodology for analyzing solar reflective roof technologies on commercial buildings. Building and Environment, 45(2), 453. doi:10.1016/j.buildenv.2009.07.001"

Lufa Farms. (2013). Lufa Farms. Retrieved February 15, 2013, from https://lufa.com/

MacRae, R., Gallant, E., Patel, S., Michalak, M., Bunch, M., \& Schaffner, S. (2010). Could Toronto provide $10 \%$ of its fresh vegetable requirements from within its own boundaries? Matching consumption requirements with growing spaces. Journal of Agriculture, Food Systems, and Community Development, 1(2), 105-127.

Mihalakakou, G., \& Ferrante, A. (2000). Energy conservation and potential of a sunspace: sensitivity analysis. Energy Conversion and Management, 41(12), 1247-1264.

Natural Resources Canada. (2008). EE4 Software, Version 1.7 - Modelling Guide. Retrieved from http://canmetenergy.nrcan.gc.ca/sites/canmetenergy.nrcan.gc.ca/files/files/pubs/EE4-English2008-02-01.pdf

Niachou, A., Papakonstantinou, K., Santamouris, M., Tsangrassoulis, A., \& Mihalakakou, G. (2001). Analysis of the green roof thermal properties and investigation of its energy performance. Energy and Buildings, 33(7), 719. doi:10.1016/S0378-7788(01)00062-7" 
Pervila, M., Remes, L., \& Kangasharju, J. (2012). Harvesting heat in an urban greenhouse. 1st ACM Conference on Urban Networking, CoNEXT UrbaNe 2012, December 10, 2012 - December 10, 7-12. doi:10.1145/2413236.2413239

Rodriguez, O. (2009). London Rooftop Agriculture: a preliminary estimate of London's productive potential. (Unpublished MArch). Cardiff University, Cardiff.

Scott, D. (2011). Reducing a building's heating load with a rooftop greenhouse. Sheffield: University of Sheffield. Retrieved from http://www.rooftopgreenhouse.co.uk/downloads/SheffieldUniReport.pdf

Stanghellini, C. (1987). Transpiration of greenhouse crops: An aid to climate management. (PhD, Landbouwuniversiteit Wageningen).

Statistics Canada. (2012). The Canadian population in 2011: Population Counts and Growth. Ottawa: Statistics Canada. Retrieved from http://www12.statcan.gc.ca/census-recensement/2011/as-sa/98310-x/98-310-x2011001-eng.pdf

Stec, W. J., Paassen, A. H. C. v., \& Maziarz, A. (2005). Modelling the double skin façade with plants. Energy and Buildings, 37(5), 419. doi:10.1016/j.enbuild.2004.08.008"

Swann, B. (1996). Establishing design criteria for the incorporation of highly glazed spaces into the domestic building envelope. (PhD, Cranfield University).

Yu, G., Gao, G., \& Gong, X. (2010). Experimental Research on Heat Flux for Integration of Flat Solar Collectors and Roofs. Power and Energy Engineering Conference (APPEEC), 2010 Asia-Pacific, 1-4. doi:10.1109/APPEEC.2010.5448992

Zhou, J., \& Chen, Y. (2010). A review on applying ventilated double-skin facade to buildings in hotsummer and cold-winter zone in China. Renewable and Sustainable Energy Reviews, 14(4), 1321. doi:10.1016/j.rser.2009.11.017" 


\section{Appendix A: Interior loads}

\section{Internal gains summary}

\begin{tabular}{|c|c|c|c|c|c|c|}
\hline \multicolumn{7}{|c|}{ Moderate loads (ASHRAE Active Storage) } \\
\hline Type & $\begin{array}{l}\text { Maximum } \\
\text { Sensible }\left(\mathrm{W} / \mathrm{m}^{2}\right)\end{array}$ & $\begin{array}{l}\text { Maximum } \\
\text { Latent }\left(\mathrm{W} / \mathrm{m}^{2}\right)\end{array}$ & Occupancy & $\begin{array}{l}\text { Max Power } \\
\text { Consumption } \\
\left(\mathrm{W} / \mathrm{m}^{2}\right)\end{array}$ & Variation profile & Dimming profile \\
\hline Equipment & 2.153 & 0 & 0 & 2.153 & BLDG: Warehouse - Equip & - \\
\hline Fluorescent lighting & 8.611 & 0 & 0 & 8.611 & BLDG: Warehouse - Light & on continuously \\
\hline \multicolumn{7}{|l|}{ Evapotranspiration } \\
\hline Type & $\begin{array}{l}\text { Maximum } \\
\text { Sensible }\left(\mathrm{W} / \mathrm{m}^{2}\right)\end{array}$ & $\begin{array}{l}\text { Maximum } \\
\text { Latent }\left(\mathrm{W} / \mathrm{m}^{2}\right)\end{array}$ & Occupancy & $\begin{array}{l}\text { Max Power } \\
\text { Consumption } \\
\left(\mathrm{W} / \mathrm{m}^{2}\right)\end{array}$ & Variation profile & Dimming profile \\
\hline Equipment & 2.153 & 0 & 0 & 2.153 & BLDG: Warehouse - Equip & - \\
\hline Fluorescent lighting & 8.611 & 0 & 0 & 8.611 & BLDG: Warehouse - Light & on continuously \\
\hline Evapotranspiration & 0 & 205 & 0 & 0 & Plant 205max & - \\
\hline \multicolumn{7}{|c|}{ Evapotranspiration + HPS lights } \\
\hline Type & $\begin{array}{l}\text { Maximum } \\
\text { Sensible }\left(\mathrm{W} / \mathrm{m}^{2}\right)\end{array}$ & $\begin{array}{l}\text { Maximum } \\
\text { Latent }\left(\mathrm{W} / \mathrm{m}^{2}\right)\end{array}$ & Occupancy & $\begin{array}{l}\text { Max Power } \\
\text { Consumption } \\
\left(\mathrm{W} / \mathrm{m}^{2}\right)\end{array}$ & Variation profile & Dimming profile \\
\hline Equipment & 2.153 & 0 & 0 & 2.153 & BLDG: Warehouse - Equip & - \\
\hline Fluorescent lighting & 8.611 & 0 & 0 & 8.611 & BLDG: Warehouse - Light & on continuously \\
\hline Evapotranspiration & 0 & 205 & 0 & 0 & Plant 205max & - \\
\hline HPS lighting & 30 & 0 & 0 & 43 & HPS lighting & on continuously \\
\hline
\end{tabular}

\section{Variation profiles}

\section{Equipment \& Fluorescent lighting}
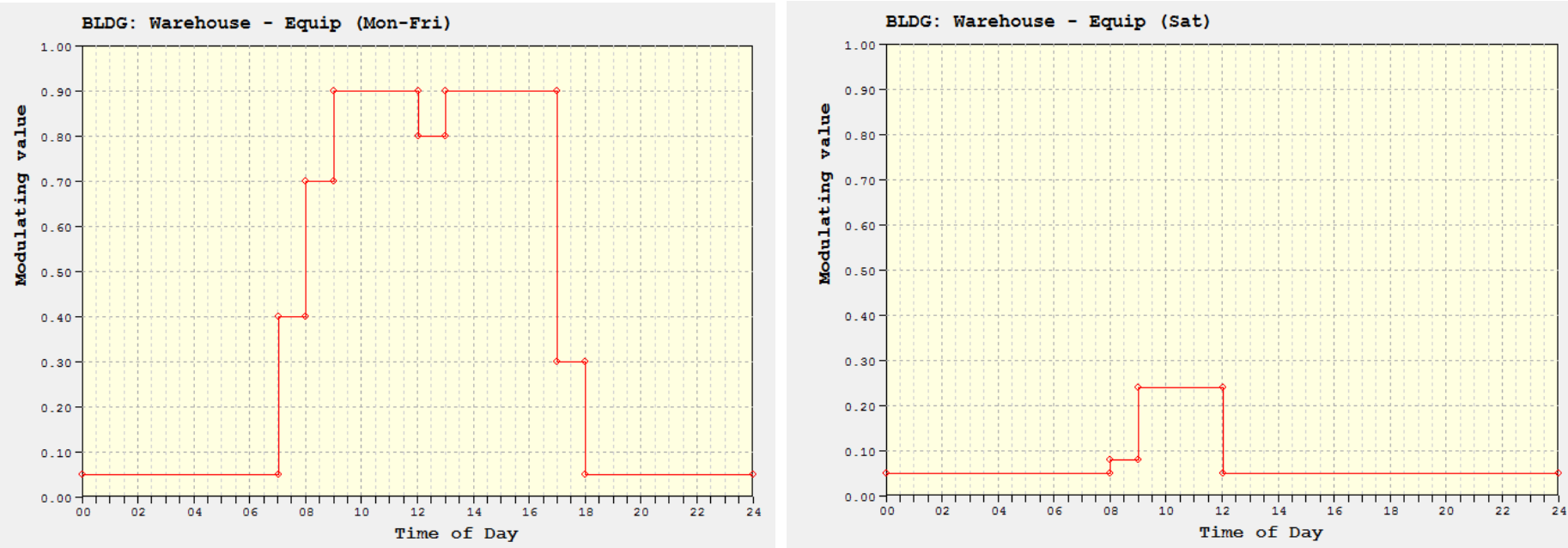


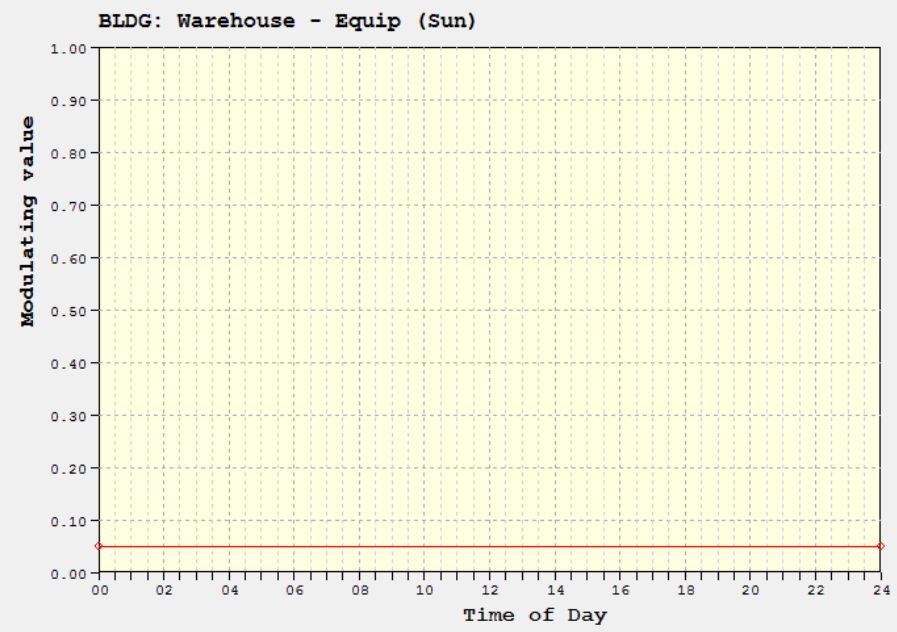

\section{Evapotranspiration}
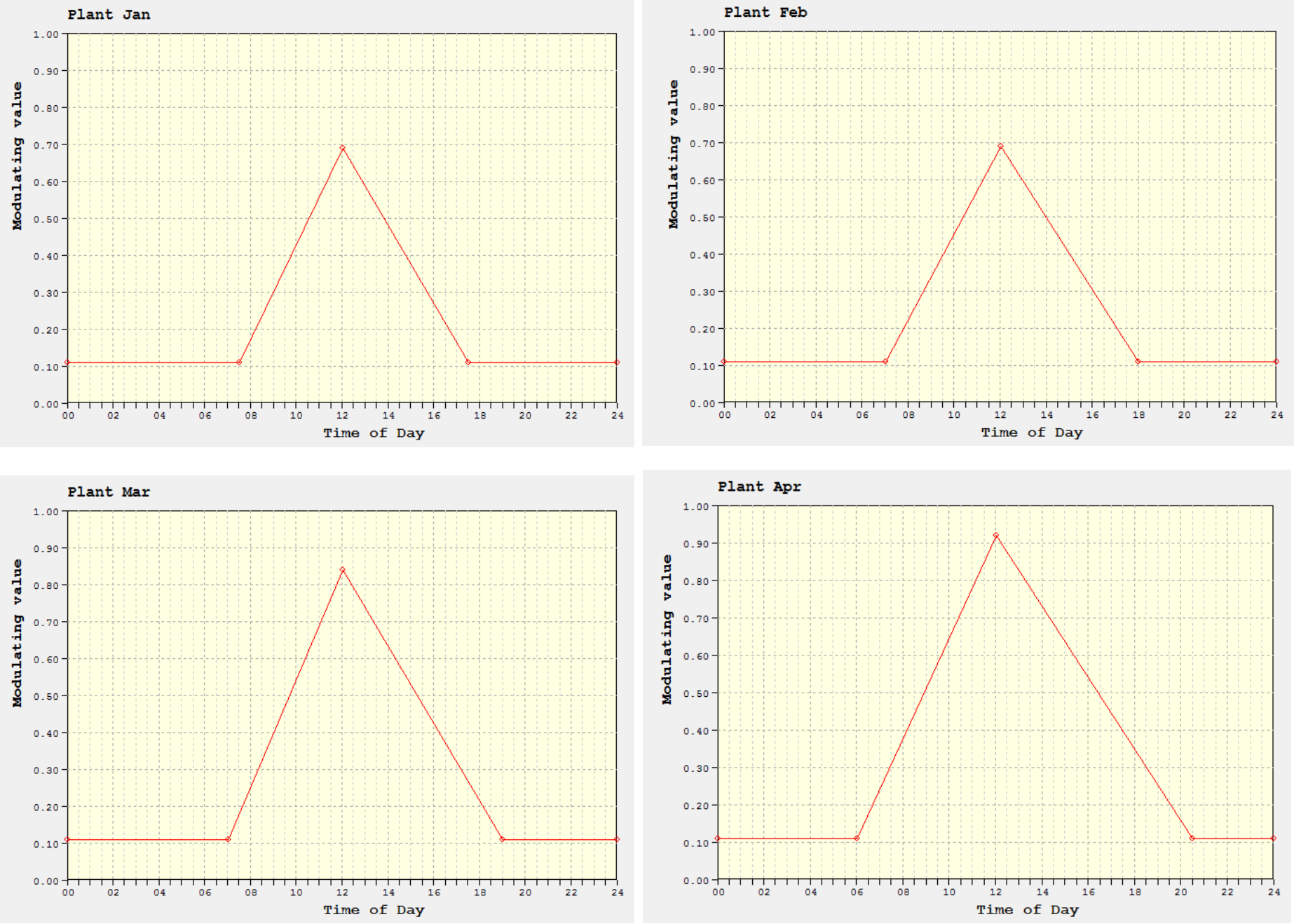

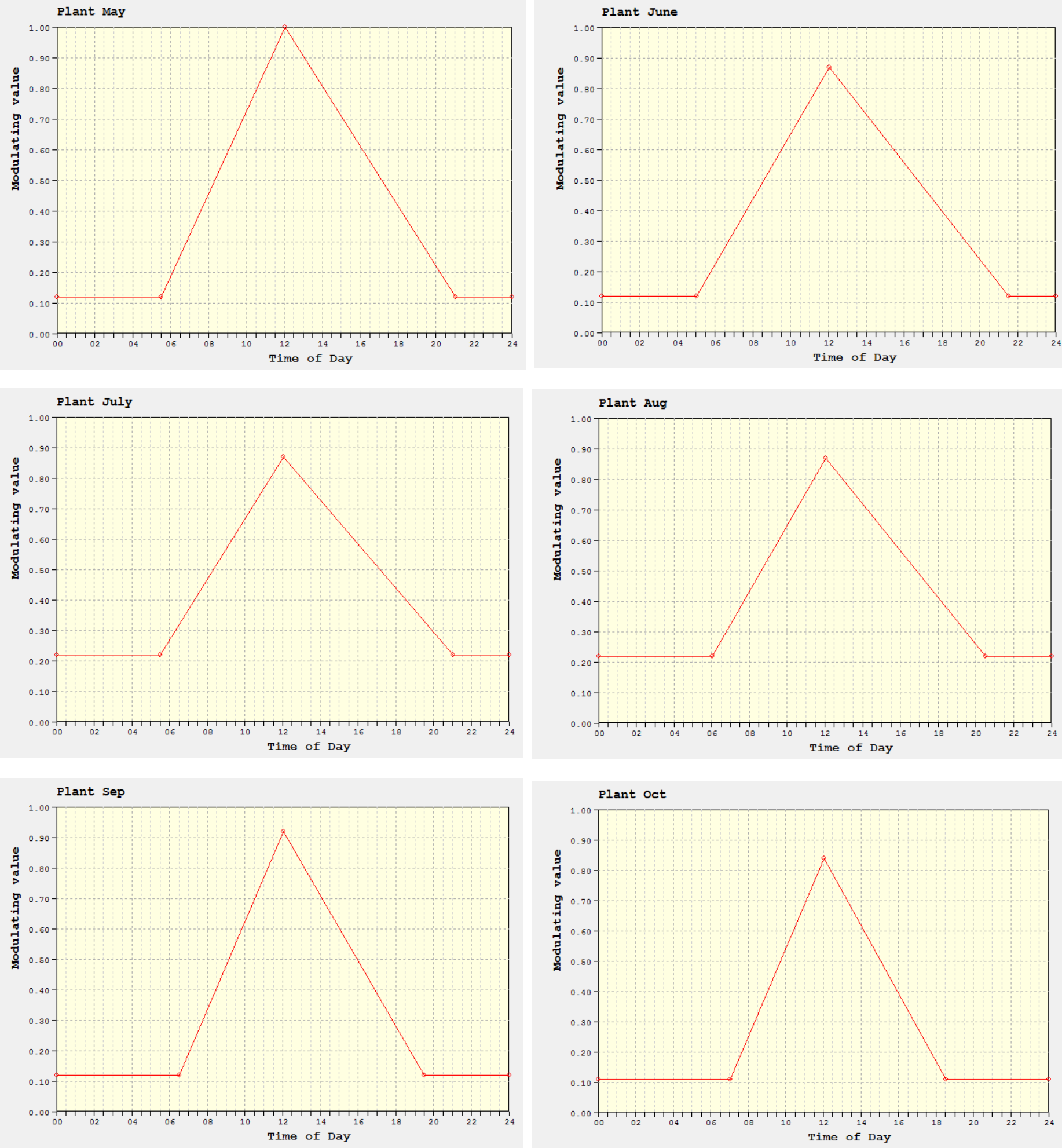

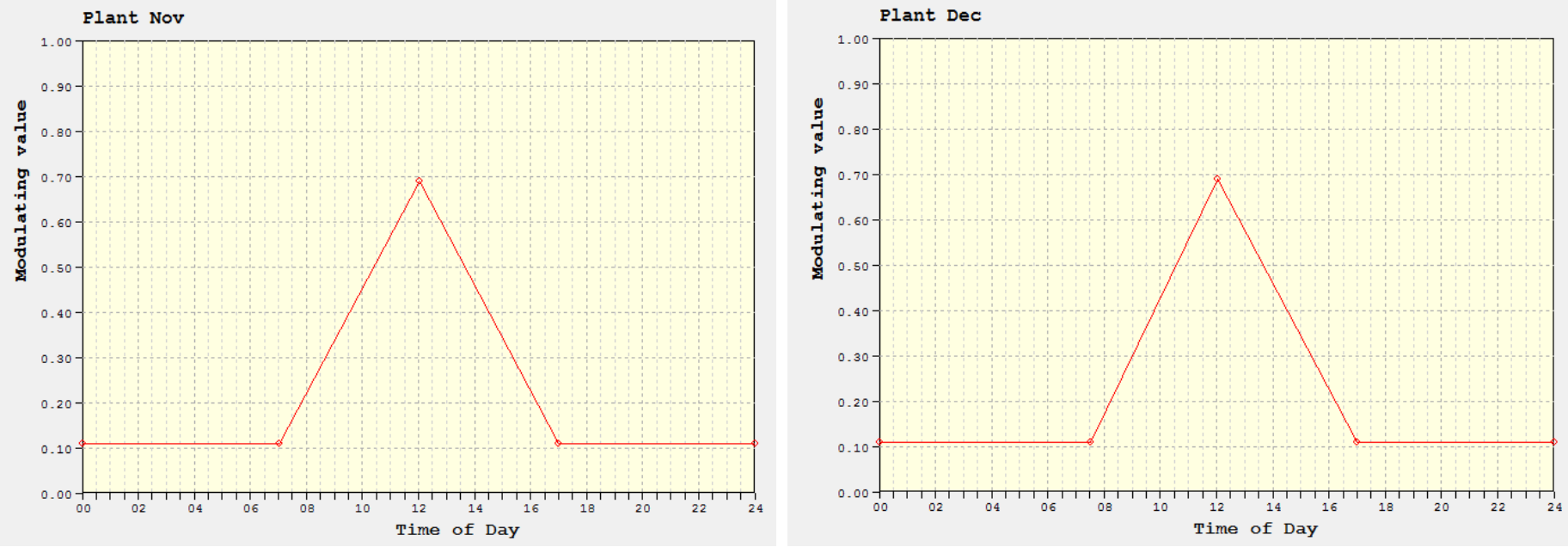

$\underline{\text { HPS lights }}$
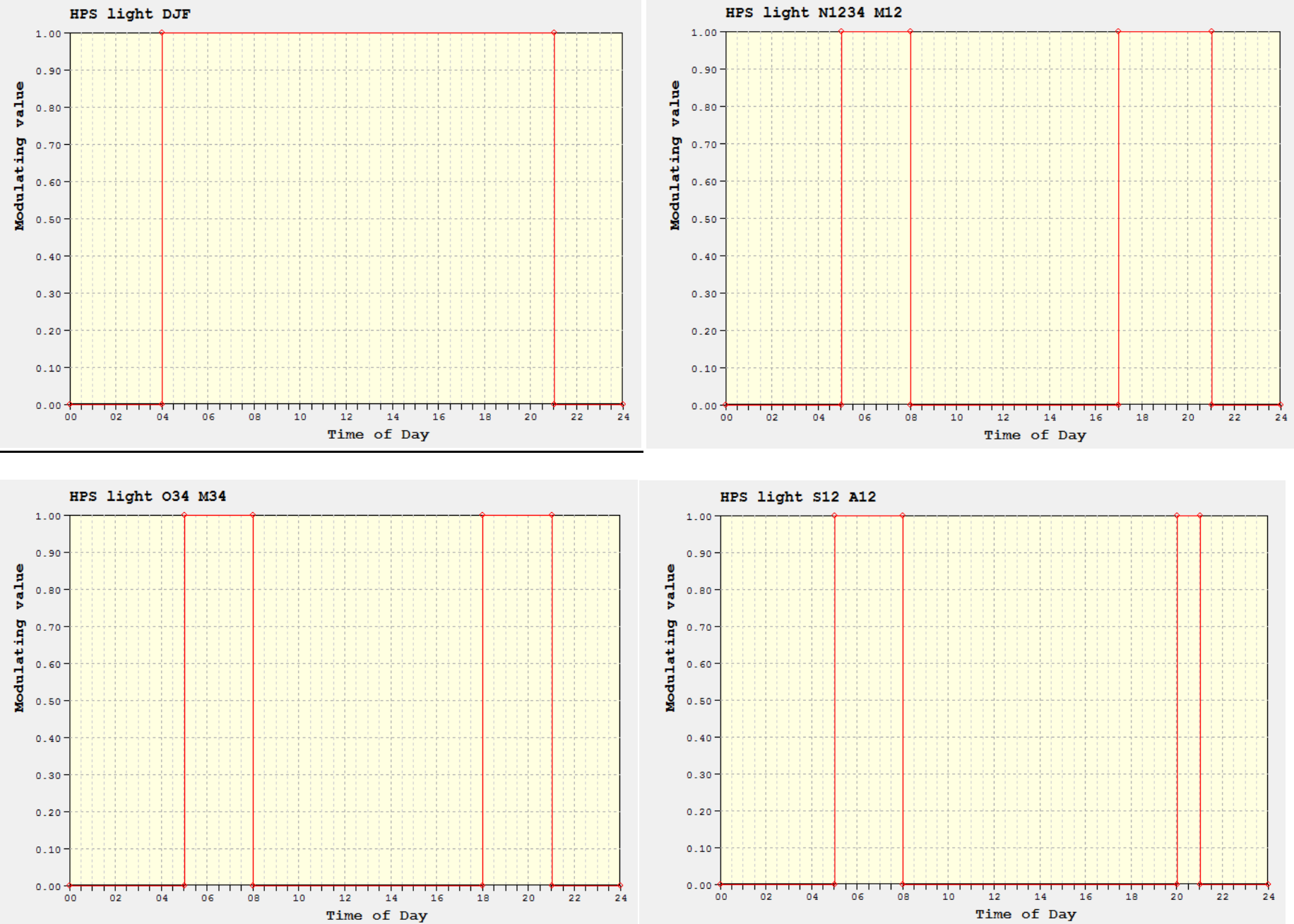


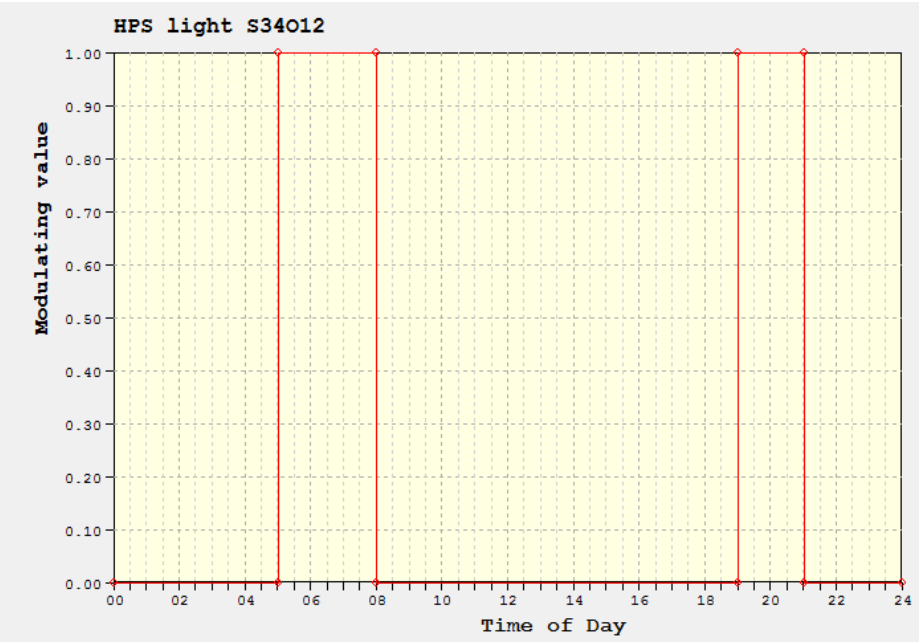

[HPS light profiles applied in the weeks of the month indicated in the title; for example, the first profile is applied for the full months of December, January and February, while the second is on for all of November and the first and second week of March. The lights are always off from the third week of April to the first week of September.] 